\title{
\#USGS
}

science for a changing world

Prepared in cooperation with the Missouri River Recovery Program

\section{Assessment of Adult Pallid Sturgeon Fish Condition, Lower Missouri River-Application of New Information to the Missouri River Recovery Program}

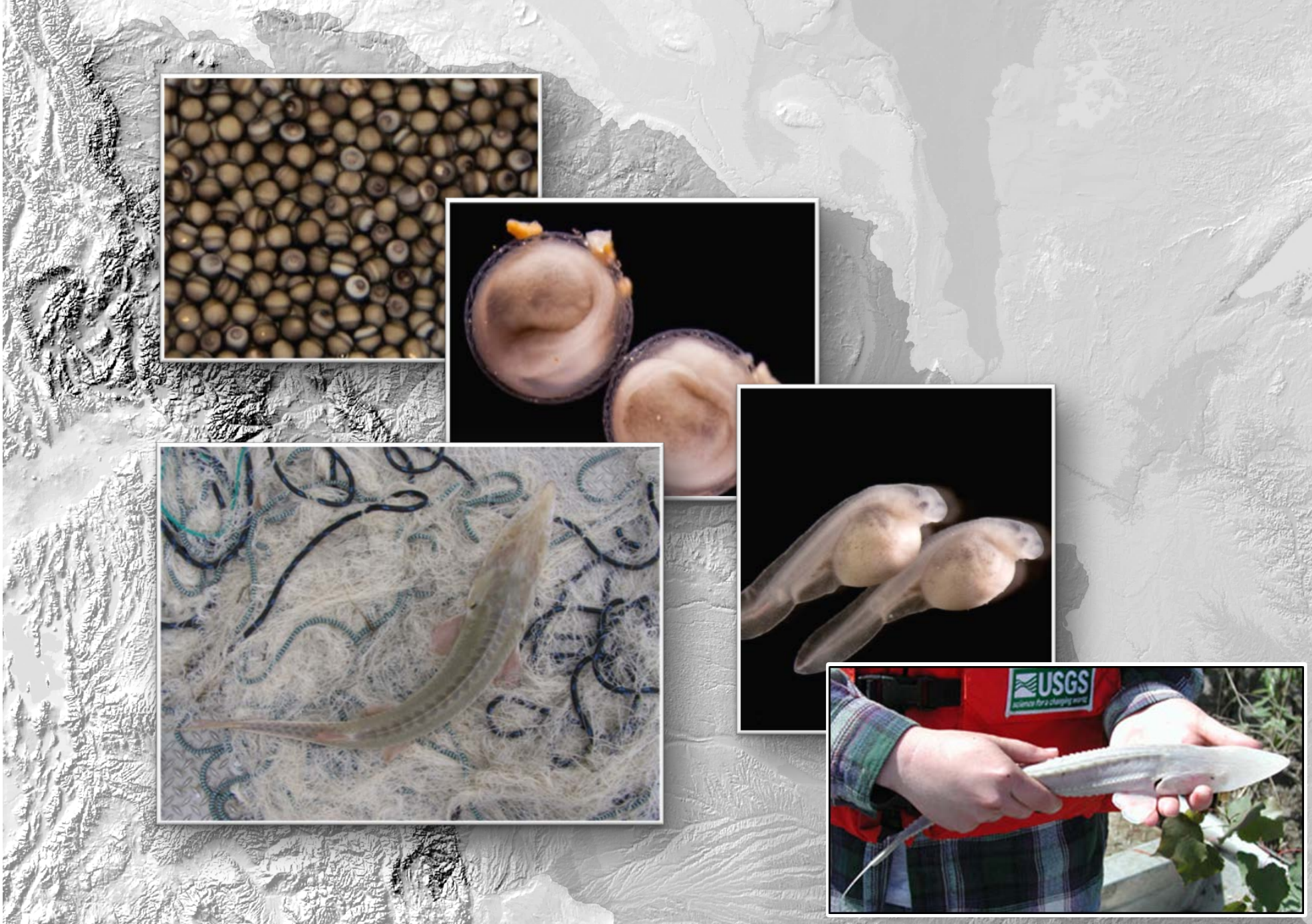

Open-File Report 2017-1121

U.S. Bepartment of the Interior U.S. Geological Survey 
Cover photograph index:

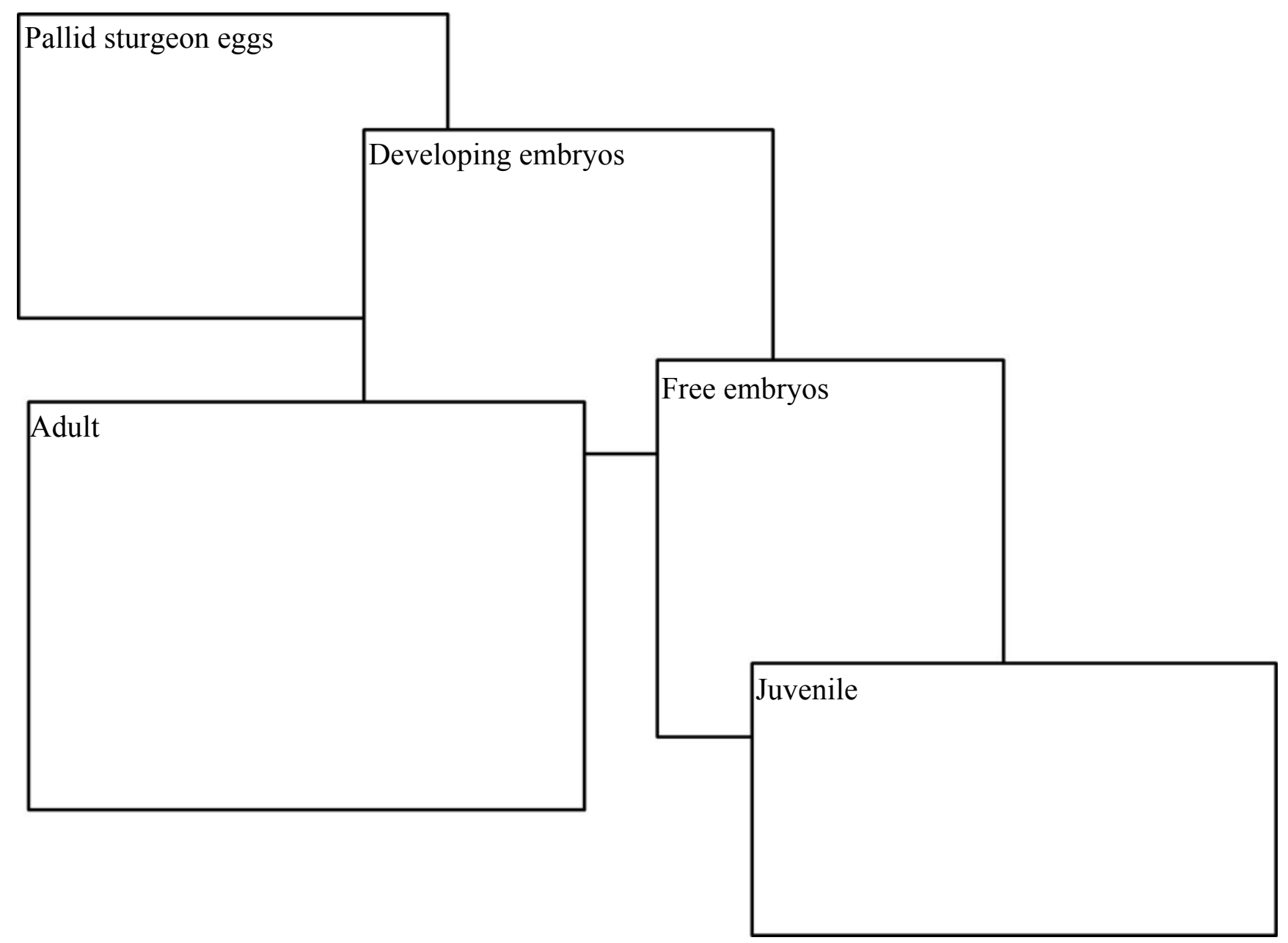

Background image: shaded relief map of the Missouri River drainage basin, US Geological Survey, EROS Data Center.

Photographs by U.S. Geological Survey personnel 


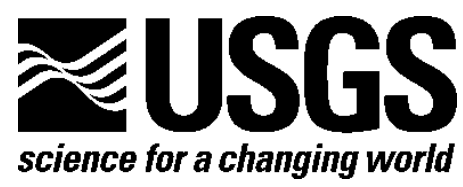

Prepared in cooperation with the U.S. Army Corps of Engineers, Missouri River Recovery Program

\section{Assessment of Adult Pallid Sturgeon Fish Condition, Lower Missouri River-Application of New Information to the Missouri River Recovery Program}

By Michael T. Randall, Michael E. Colvin, Kirk D. Steffensen, Timothy L. Welker, Landon L. Pierce, and Robert B. Jacobson

Open-File Report 2017-1121

U.S. Department of the Interior

U.S. Geological Survey 


\section{U.S. Department of the Interior \\ RYAN K. ZINKE, Secretary}

\section{U.S. Geological Survey \\ William H. Werkheiser, Acting Director}

U.S. Geological Survey, Reston, Virginia: 2017

For more information on the USGS-the Federal source for science about the Earth, its natural and living resources, natural hazards, and the environment-visit http://www.usgs.gov/ or call 1-888-ASK-USGS (1-888-275-8747).

For an overview of USGS information products, including maps, imagery, and publications, visit http://www.usgs.gov/pubprod/.

Any use of trade, firm, or product names is for descriptive purposes only and does not imply endorsement by the U.S. Government.

Although this information product, for the most part, is in the public domain, it also may contain copyrighted materials as noted in the text. Permission to reproduce copyrighted items must be secured from the copyright owner.

Suggested citation:

Randall, M.T., Colvin, M.E., Steffensen, K.D., Welker, T.L., Pierce, L.L., and Jacobson, R.B., 2017, Assessment of adult pallid sturgeon fish condition, Lower Missouri River-Application of new information to the Missouri River Recovery Program: U.S. Geological Survey Open-File Report 2017-1121, 103 p., https://doi.org/10.3133/ofr20171121. 


\section{Contents}

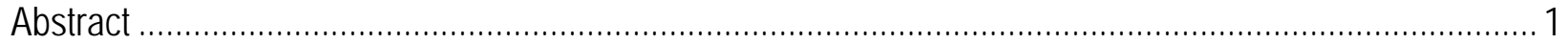

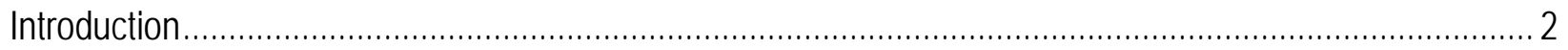

Nebraska Game and Park Commission's Analysis ....................................................................... 3

Background on Missouri River Pallid Sturgeon Management........................................................ 5

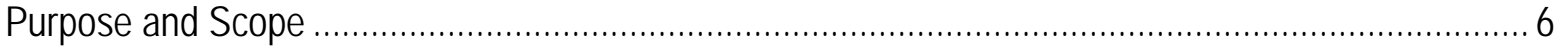

Charge to the Committee to Evaluate Declining Pallid Sturgeon Condition ........................................ 6

Missouri River Recovery Context ...........................................................................................

Question 1-Is Pallid Sturgeon Condition Declining? ..................................................................... 10

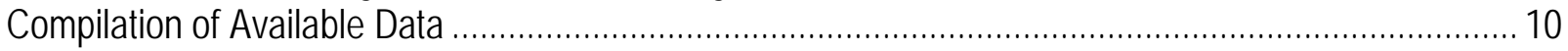

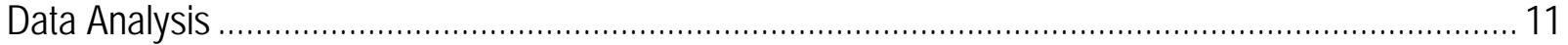

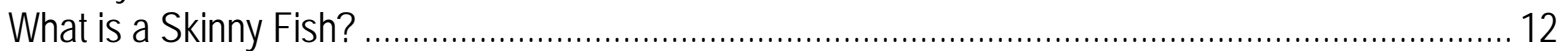

Analysis of Covariance Methodology ............................................................................ 19

Results of Kn Analyses ....................................................................................................... 23

Discussion—Do Lower Missouri River Pallid Sturgeon Have Declining Condition? ............................... 59

Trends Based on Condition Indices .................................................................................... 59

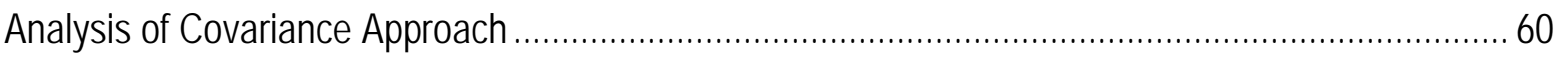

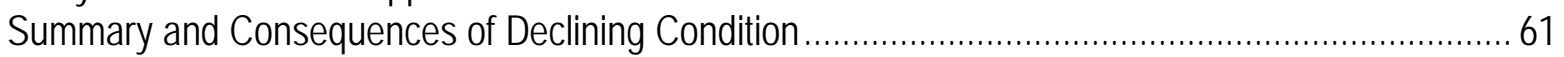

Question 2-What are Likely Causes of Declining Pallid Sturgeon Condition? .......................................... 64

Hypothesis_Pallid Sturgeon Have Health Problems that Limit Condition ........................................... 64

Hypothesis-There is Too Much Inter- and Intraspecific Competition for Food or Space Resources ....... 64

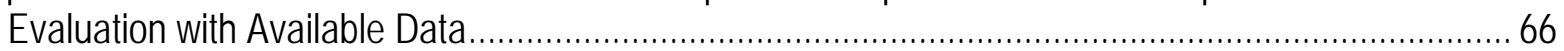

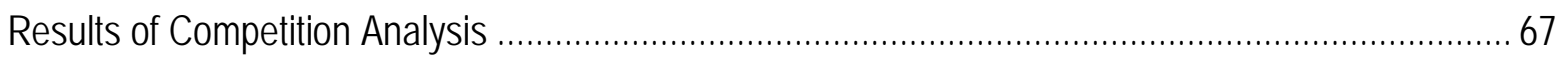

Hypothesis-Long- and Short-Term Trends in River Morphology Have Diminished Habitat for Pallid

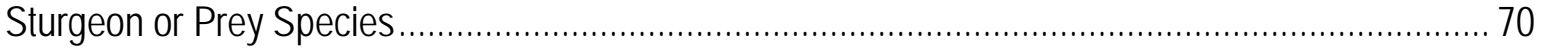

Evaluation with Available Data................................................................................................. 74

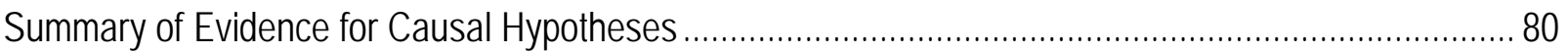

Discussion-Future Directions in Assessing Pallid Sturgeon Condition ................................................. 80

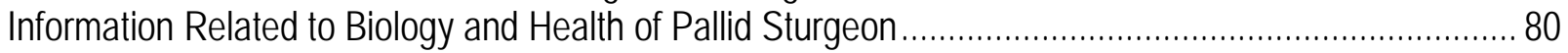

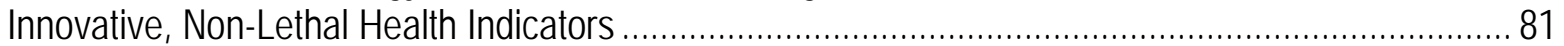

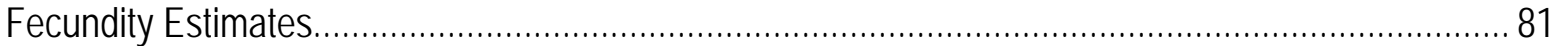

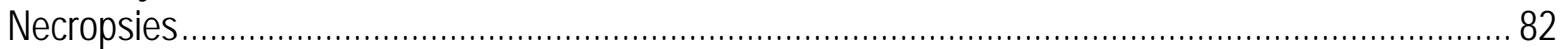

Early Life and Fish Origin............................................................................................... 83

Information Related to Pallid Sturgeon Within the Missouri River Ecosystem ....................................... 83

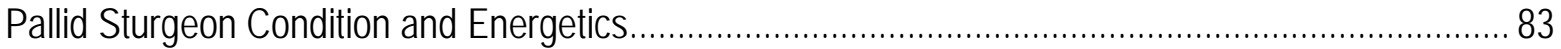

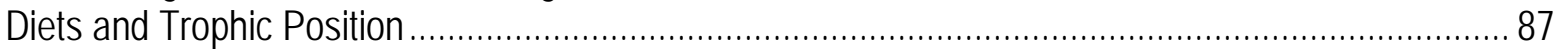

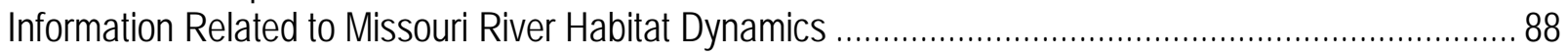

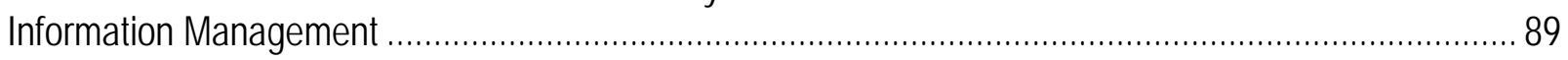

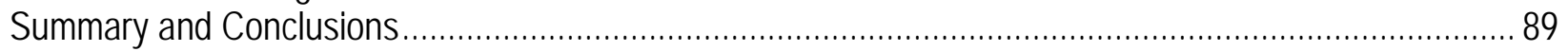

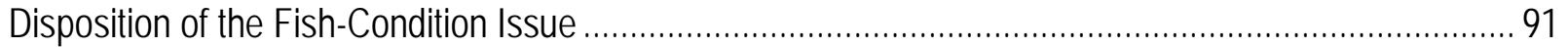

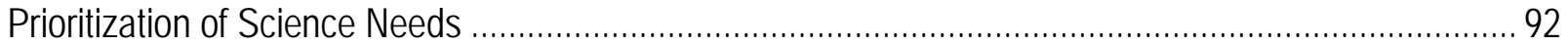

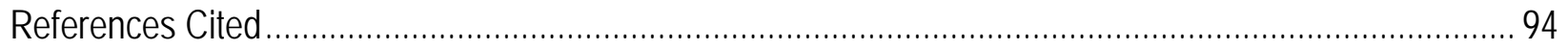


Figures

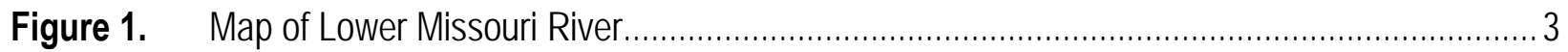

Figure 2. Declining pallid sturgeon condition (Kn) over time....................................................... 4

Figure 3. Hydrographs of selected Lower Missouri River streamflow-gaging stations showing the

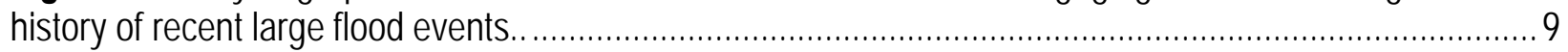

Figure 4. Shuman and others (2011) length-weight relation (LWR) used to calculate Kn....................13

Figure 5. Shuman and alternative length-weight relations (LWR), used for calculating $\mathrm{Kn}$ and

Alternative Kn. ............................................................................................................ 15

Figure 6. Shuman length-weight relationship (LWR), the Alternative Kn LWR, and all length-weight data from the Missouri River.................................................................................................... 16

Figure 7. Shuman Kn variation of pallid sturgeon from same-day to second-day recapture .................17

Figure 8. Mean Shuman Kn values for the Missouri River basin since 2003 …….............................. 24

Figure 9. Mean Alternative Kn values for the Missouri River basin since 2003 .................................2 25

Figure 10. Shuman and Alternative Kn by selected segment by year ................................................ 26

Figure 11. Histograms of $A$, Shuman $\mathrm{Kn}$ values and $B$, Alternative $\mathrm{Kn}$ values for pallid sturgeon from the Missouri River. 27

Figure 12. Pallid sturgeon weight and length for 2003 to 2016 grouped by Missouri River basin. ...........51

Figure 13. Plot of weight and length on log scale for pallid sturgeon captured in Missouri River basin...52 Figure 14. Plot of condition and day of year for pallid sturgeon captured in the upper and lower Missouri

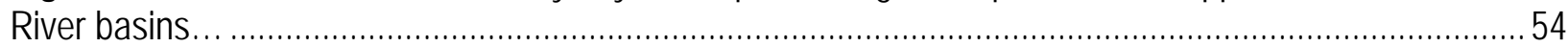

Figure 15. Plot of estimated weight and year for pallid sturgeon lengths ..........................................55

Figure 16. Estimated weight for varying length of Lower Missouri River basin pallid sturgeon among

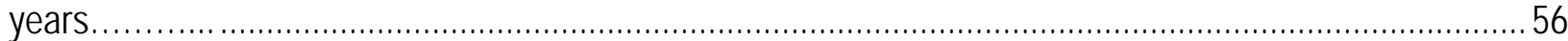

Figure 17. Length-specific condition values for upper Missouri River basin pallid sturgeon calculated from predicted weights for 2015 and 2016.

Figure 18. Model estimated weights for Lower Missouri River basin pallid sturgeon from 2011 to 2016.58 Figure 19. Graphs of water-surface elevation over time for selected discharges, selected streamgages, Missouri River..

Figure 20. Changes in the construction reference plane, Sioux City, lowa, to the confluence with the

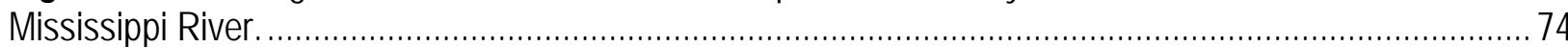

Figure 21. Mean streambed elevation plots for selected streamgages, Missouri River, 1990-2016.......76

Figure 22. Velocity histories for selected streamgages, Missouri River 1928-2016 ............................77

Figure 23. Histograms of depth and velocity by segment of the Yellowstone, Upper Missouri, and Lower Missouri Rivers.....

Figure 24. Relation between flow exceedance and mean velocity at selected streamflow-gaging stations. 
Tables

Table 1. Distribution of records by basin, segment, and year....................................................... 18

Table 2. Count of hatchery-origin fish compared with wild-origin fish by year....................................19

Table 3. Number of captures of pallid sturgeon by location, origin, size class, and year for $A$, upper basin and $B$, lower basin..

Table 4. Descriptive statistics of Shuman and Alternative Kn values for the full and reduced datasets of Missouri River pallid sturgeon.

Table 5. Count of observations of pallid sturgeon in each condition class by basin and year, using $A$,

Shuman $\mathrm{Kn}$ and $B$, Alternative $\mathrm{Kn}$..

Table 6. Percentage of observations of pallid sturgeon in each condition class by basin and year, using $A$, Shuman $\mathrm{Kn}$ and $B$, Alternative $\mathrm{Kn}$..

Table 7. Count of observations of pallid sturgeon in each condition class by basin and segment, using $A$,

Shuman $\mathrm{Kn}$ and $B$, Alternative $\mathrm{Kn}$..

Table 8. Percentage of observations of pallid sturgeon in each condition class by basin and segment, using $A$, Shuman $\mathrm{Kn}$ and $B$, Alternative $\mathrm{Kn}$..

Table 9. Count of observations of pallid sturgeon in each condition class, using $A$, Shuman $\mathrm{Kn}$ and $B$, Alternative Kn.

Table 10. Percentage of observations of pallid sturgeon in each condition class, using $A$, Shuman $\mathrm{Kn}$ and $B$, Alternative Kn.

Table 11. Count of observations of pallid sturgeon in each condition class by year and origin (hatchery or wild) using $A$, Shuman $\mathrm{Kn}$ and $B$, Alternative $\mathrm{Kn}$....

Table 12. Percentage of observations of pallid sturgeon in each condition class by year and origin (hatchery or wild) using $A$, Shuman Kn and $B$, Alternative Kn.

Table 13. Count of observations of pallid sturgeon in each condition class by origin, using $A$, Shuman

$\mathrm{Kn}$ and $B$, Alternative $\mathrm{Kn}$.....

Table 14. Count of observations of segment 9 pallid sturgeon in each condition class by year using $A$, Shuman $\mathrm{Kn}$ and $B$, Alternative $\mathrm{Kn}$..

Table 15. Count and percentage of segment 9 pallid sturgeon by bend (for bends with $\mathrm{N}$ greater than or equal to 30) using $A$, Shuman $\mathrm{Kn}$ and $B$, Alternative $\mathrm{Kn}$....

Table 16. Count of observations of segment 9 pallid sturgeon in condition classes -3 to -1 standard deviation by size class and year, using $A$, Shuman $\mathrm{Kn}$ and $B$, Alternative $\mathrm{Kn}$..

Table 17. Count of observations of segment 9 pallid sturgeon in condition classes -3 to -1 standard deviation by origin and year, using $A$, Shuman $\mathrm{Kn}$ and $B$, Alternative $\mathrm{Kn}$.....

Table 18. Model selection results for candidate length-weight models fit to upper and lower Missouri River basin pallid sturgeon from 2003 to 2016.

Table 19. Summary of the correlation statistics for hypothesized independent variables that may be affecting juvenile (less than 600 millimeters) pallid sturgeon condition in the lower Missouri River............. 68

Table 20. Summary of the correlation statistics for hypothesized independent variables that may be affecting subadult (600-800 millimeters) pallid sturgeon condition in the lower Missouri River..................69 Table 21. Summary of the correlation statistics for hypothesized independent variables that may be affecting adult (greater than 800 millimeters) pallid sturgeon condition in the lower Missouri River.. 


\section{Conversion Factors}

U.S. customary units to International System of Units

\begin{tabular}{|c|c|c|}
\hline (2) & By & To obtain \\
\hline \multicolumn{3}{|c|}{ Length } \\
\hline mile (mi) & 1.609 & kilometer $(\mathrm{km})$ \\
\hline \multicolumn{3}{|c|}{ Flow rate } \\
\hline cubic foot per second $\left(\mathrm{ft}^{3} / \mathrm{s}\right)$ & 0.02832 & cubic meter per second $\left(\mathrm{m}^{3} / \mathrm{s}\right)$ \\
\hline \multicolumn{3}{|c|}{ International System of Units to U.S. customary units } \\
\hline Multiply & By & To obtain \\
\hline \multicolumn{3}{|c|}{ Length } \\
\hline millimeter $(\mathrm{mm})$ & 0.03937 & inch (in.) \\
\hline $\operatorname{meter}(\mathrm{m})$ & 3.281 & foot $(\mathrm{ft})$ \\
\hline meter $(\mathrm{m})$ & 1.094 & yard (yd) \\
\hline \multicolumn{3}{|c|}{ Flow rate } \\
\hline meter per second $(\mathrm{m} / \mathrm{s})$ & 3.281 & foot per second $(\mathrm{ft} / \mathrm{s})$ \\
\hline \multicolumn{3}{|l|}{ 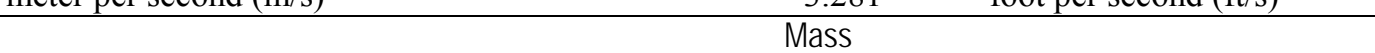 } \\
\hline gram $(\mathrm{g})$ & 0.03527 & ounce, avoirdupois (oz) \\
\hline kilogram $(\mathrm{kg})$ & 2.205 & pound avoirdupois (lb) \\
\hline
\end{tabular}

Temperature in degrees Celsius $\left({ }^{\circ} \mathrm{C}\right)$ may be converted to degrees Fahrenheit $\left({ }^{\circ} \mathrm{F}\right)$ as ${ }^{\circ} \mathrm{F}=\left(1.8 \times{ }^{\circ} \mathrm{C}\right)+32$.

Temperature in degrees Fahrenheit $\left({ }^{\circ} \mathrm{F}\right)$ may be converted to degrees Celsius $\left({ }^{\circ} \mathrm{C}\right)$ as ${ }^{\circ} \mathrm{C}=\left({ }^{\circ} \mathrm{F}-32\right) / 1.8$.

\section{Datum}

Vertical coordinate information is referenced to the North American Vertical Datum of 1988 (NAVD 88).

Horizontal coordinate information is referenced to the North American Datum of 1983 (NAD 83).

Altitude, as used in this report, refers to distance above the vertical datum. 


\title{
Assessment of Adult Pallid Sturgeon Fish Condition, Lower Missouri River-Application of New Information to the Missouri River Recovery Program
}

Michael T. Randall, ${ }^{1}$ Michael E. Colvin, ${ }^{2}$ Kirk D. Steffensen, ${ }^{3}$ Timothy L. Welker,${ }^{4}$ Landon L. Pierce,${ }^{5}$ and Robert B. Jacobson, ${ }^{1}$

\begin{abstract}
During spring 2015, Nebraska Game and Parks Commission (NGPC) biologists noted that pallid sturgeon (Scaphirhynchus albus) were in poor condition during sampling associated with the Pallid Sturgeon Population Assessment Project and NGPC's annual pallid sturgeon broodstock collection effort. These observations prompted concerns that reduced fish condition could compromise reproductive health and population growth of pallid sturgeon. There was a further concern that compromised condition could possibly be linked to U.S. Army Corps of Engineers management actions and increase jeopardy to the species. An evaluation request was made to the Missouri River Recovery Program and the Effects Analysis Team was chartered to evaluate the issue. Data on all Missouri River pallid sturgeon captures were requested and received from the National Pallid Sturgeon Database. All data were examined for completeness and accuracy; 12,053 records of captures between 200 millimeters fork length (mm FL) and 1,200 $\mathrm{mm}$ FL were accepted. We analyzed condition using (1) the condition formula (Kn) from Shuman and others (2011); (2) a second Kn formulation derived from the 12,053 records (hereafter referred to as "Alternative Kn"); and (3) an analysis of covariance (ANCOVA) approach that did not rely on a Kn formulation. The Kn data were analyzed using group (average annual $\mathrm{Kn}$ ) and individual (percentage in low, normal, and robust conditions) approaches. Using the Shuman Kn formulation, annual mean Kn was fairly static from 2005 to 2011 (although always higher in the upper basin), declined from 2012 to 2015, then remained either static (lower basin) or increasing (upper basin) in 2016. Under the Alternative Kn formulation, the upper basin showed no decline in $\mathrm{Kn}$, whereas the lower basin displayed the same trend as the Shuman Kn formulation. Using both formulations, the individual approach revealed a more complex situation; at the same times and locations that there are fish in poor condition, there are nearby fish in normal or robust condition. The ANCOVA approach revealed that fish condition at size changed between 400 and $600 \mathrm{~mm}$ and that some of the apparent trend in low condition was caused by differences in sample size across the size range of the population (that is, greater catch of intermediate-sized fish compared to large fish). We examined basin, year, origin (hatchery compared to wild), segment, and size class for effects on condition and concluded that, since 2012, there has been an increase in the percentage of pallid sturgeon in low condition. There are
\end{abstract}

\footnotetext{
${ }^{1}$ U.S. Geological Survey

${ }^{2}$ Mississippi State University

${ }^{3}$ Nebraska Game and Parks Commission

${ }^{4}$ U.S. Army Corps of Engineers

${ }^{5}$ U.S. Fish and Wildlife Service
} 
basin, year, and segment effects; origin and size class do not seem to have an effect. The lower basin, in particular segment 9 (Platte River to Kansas River), had a high percentage of lowcondition fish. Within the segment, there were bend-level effects, but the bend effect was not spatially contiguous.

We concluded that existing data confirm concerns about declining fish condition, especially in the segments between Sioux City, Iowa, and Kansas City, Missouri. Although the evidence is strong that fish condition has been in decline from 2011 to 2015, additional analysis of individual fish histories may provide more confidence in this conclusion; such analysis was beyond the scope of this effort but is part of our recommendations. The most recent data in 2016 indicate that decline of condition may have leveled off; however, the length of record is insufficient to determine whether recent declines are within the background range of variation. We recommend that monitoring of fish condition should be increased and enhanced with additional health metrics. We also recommend that, should condition continue to decline, processes are deployed to bring low-condition adult fish into the hatchery to improve nutrition and condition. We could not determine the cause of declining fish condition with available data, but we compiled information on several dominant hypotheses in two main categories: inter- or intraspecific competition for resources and habitat conditions. Data are insufficient to indicate a specific causation or solution, and it is possible that multiple causes apply. We make recommendations for additional research that can be pursued to address uncertainties in trends in fish health as well as potential causes.

\section{Introduction}

During spring 2015, Nebraska Game and Parks Commission (NGPC) biologists noted that pallid sturgeon (Scaphirhynchus albus) were in poor condition during sampling associated with the Pallid Sturgeon Population Assessment Project and NGPC's annual pallid sturgeon broodstock collection effort. The NGPC sampling was focused on the Missouri River downstream from the Platte River (river mile [RM] 549-595, fig. 1) ${ }^{1}$ but also included some additional sampling elsewhere in segments 8 and 9 . The change in condition was very notable because pallid sturgeon condition had greatly increased during and shortly after high-water events in 2010 and 2011, exceeding previous observations; however, declining condition was observed in subsequent years (Steffensen and Mestl, 2016). Concerns increased when only one reproductively ready female pallid sturgeon was collected during NGPC's 2015 broodstock collection effort; moreover, no reproductively ready female fish were collected by July 2016. Further evidence supported this concern as the pallid sturgeon research crews recaptured several fish that should have attained reproductive readiness based on the past maturation rate history, but proved to not be reproductively ready.

Poor fish condition could ultimately affect the ability of the Missouri River to sustain a naturally reproducing pallid sturgeon population. Decreased condition may lead to decreased fecundity, decreased egg size or viability, and increased time between reproductive events. If observations of decreased condition could be linked to U.S. Army Corps of Engineers (USACE) management actions, restorative actions might qualify for consideration under the Missouri River Recovery Management Plan (MRRMP).

\footnotetext{
${ }^{1}$ For consistency with management agency conventions, Missouri River longitudinal locations are referenced as river miles upstream from the confluence of the Missouri and Mississippi Rivers.
} 
Following these observations, the NGPC submitted an issue paper to the USACE Missouri River Recovery Program (MRRP) and the U.S. Fish and Wildlife Service (FWS). The MRRP science leads representing USACE and FWS assessed the issue paper and determined that further evaluation was warranted. A charter was written and issued to the pallid sturgeon Effects Analysis Team to further evaluate NGPC's concern and, if necessary, how this information would be integrated into the Missouri River Recovery Management Plan.

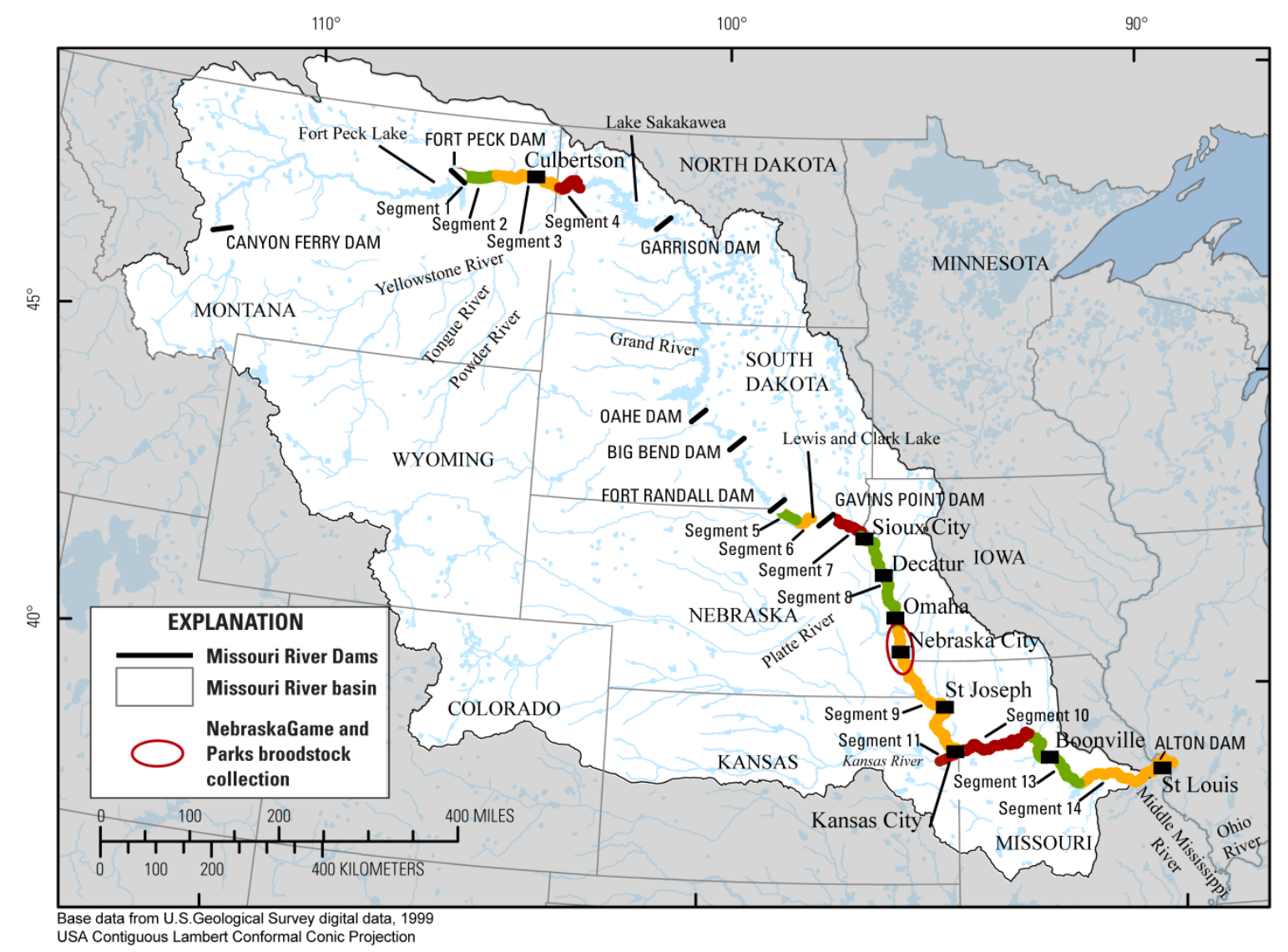

Figure 1. Map of Lower Missouri River.

\section{Nebraska Game and Park Commission's Analysis}

To further investigate the trends and changes in condition they had observed, NGPC biologists investigated an assessment of pallid sturgeon relative condition in the upper segments of the channelized Lower Missouri River (Steffensen and Mestl, 2016). This assessment utilized NGPC's multiyear (2003-15) dataset from various sampling projects. Pallid sturgeon condition was calculated as observed weight divided by standard weight, where standard weight was calculated using the standard weight equation described in Shuman and others (2011). To investigate if declines in condition were size dependent, pallid sturgeon were divided into length categories based on incremental proportional size distribution (PSD) described in Shuman and others (2006). Results indicated that pallid sturgeon PSD length categories responded slightly differently but the overall trend was that average condition started declining in 2013 and then substantially declined in 2014. The decline continued through 2015 (fig. 2). Fish condition observed in 2015 was the lowest ever observed in the channelized segments of the Missouri 
River upstream from Kansas City, Missouri. Additionally, there were no seasonal or origin (wild compared to hatchery-reared) differences observed. Steffensen and Mestl (2016) concluded that the negative trend in condition was localized to the Missouri River from Fort Randall Dam to segment 10 .
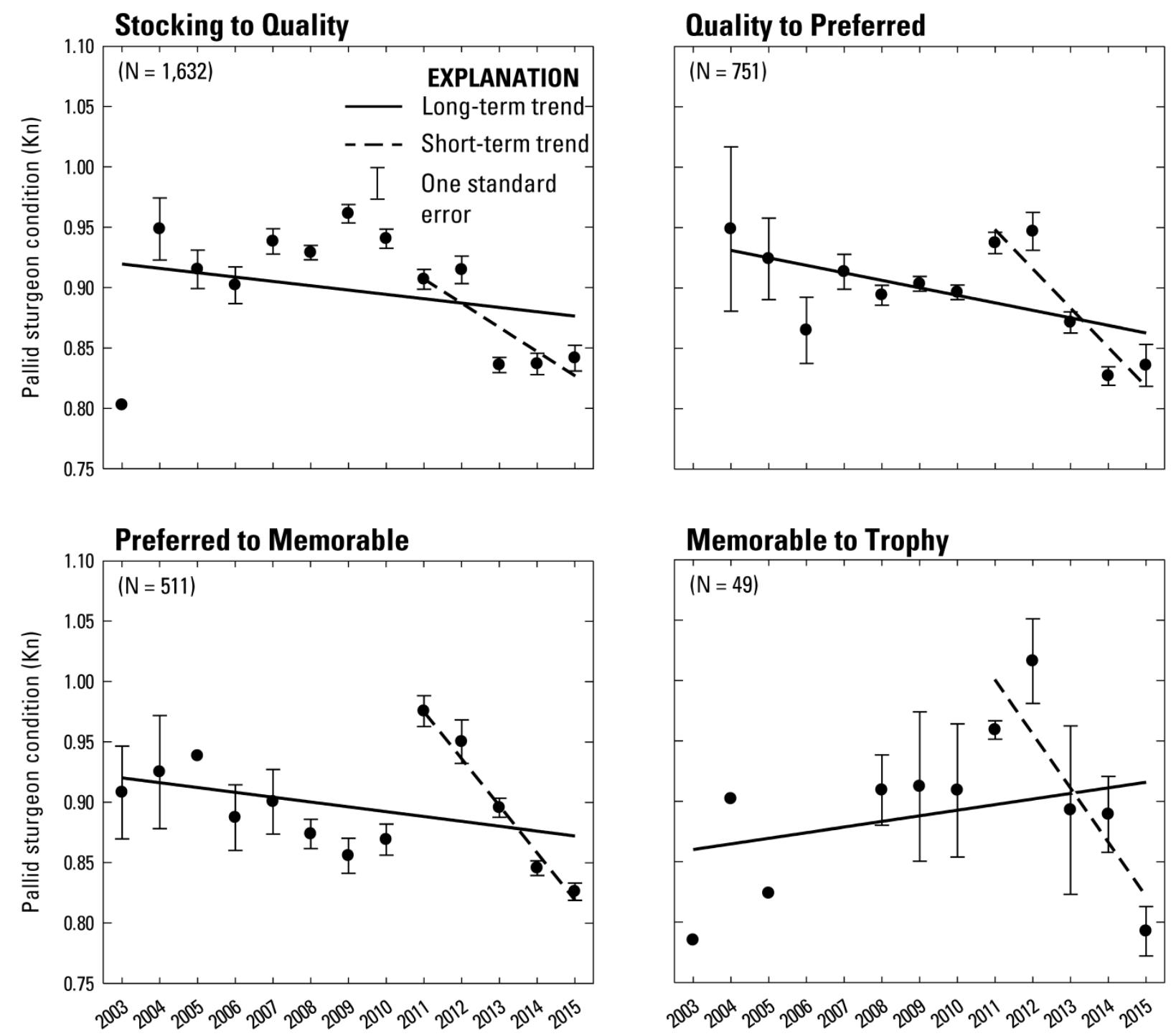

Figure 2. Declining pallid sturgeon condition (Kn) over time. From Steffensen and Mestl (2016). Size classes from Shuman and others (2006).

A secondary assessment was then completed to determine if this declining condition in pallid sturgeon was a local, regional, or range-wide phenomenon (Steffensen and others, 2016). Data were obtained from all reaches of the Missouri River (Fort Peck Dam to the confluence with the Mississippi River) and from the Middle Mississippi River (Alton Dam to the confluence with the Ohio River) and were divided into four reaches based on fragmentation by dams and evident differences in global mean Kn. Similar to the initial condition assessment, the Shuman and others (2011) condition equation was utilized but the authors divided the population into two length categories (juveniles: 400-699 mm, adults: 700-1199 mm). Results indicated that pallid sturgeon in Missouri River segments 5-11 (fig. 1) had lower condition relative to other segments 
for juvenile and adult size fish. Comparatively, pallid sturgeon in the Middle Mississippi River had the highest observed condition, whereas fish from the Upper Missouri River (Fort Peck Dam to the headwaters of Lake Sakakawea) and the Missouri River segments 13 and 14 were similar. Temporal trends for the Middle Mississippi River and Upper Missouri River reaches did not show an increase in condition after 2010 and 2011 high-water events or a following decline.

\section{Background on Missouri River Pallid Sturgeon Management}

The Missouri River has been highly altered by dams and channelization to support traditional socioeconomic purposes, including flood control, hydropower generation, public water supply, and navigation. The history of exploitation of Missouri River resources has been associated with a decline in native fish and wildlife species, and management has been focused on listed species: the pallid sturgeon, interior least tern (Sterna antillarum athalassos), and piping plover (Charadrius melodus). The pallid sturgeon was listed as endangered in 1990, and a biological opinion written in 2000 and amended in 2003 presented reasonable and prudent alternatives to guide the USACE in removing jeopardy (U.S. Fish and Wildlife Service, 2000, 2003, 2014). Since 1992, several hundred million dollars have been spent on various phases of Missouri River recovery; these costs include actions for all three listed species and some actions to promote general fish and wildlife health early in the recovery history. Despite this considerable investment, natural recruitment of pallid sturgeon on the Lower Missouri River ${ }^{2}$ is near zero and considered to be inadequate to support a viable population (U.S. Fish and Wildlife Service, 2014).

Recent evaluations of Missouri River management have concluded that Missouri River recovery would benefit from a thorough evaluation of the science underlying species population responses (Doyle and others, 2011; National Research Council, 2011). Recommendations included that the MRRP needed time to evaluate the state of knowledge and the state of accomplishment toward recovery of the species (Doyle and others, 2011). Doyle and others (2011) recommended that the evaluation should be structured as a formal "effects analysis" (EA; (Murphy and Weiland, 2011), with the goal of setting a more defensible course of action on the river. Importantly, the EA charge was limited to consideration of USACE actions and avoidance of jeopardy. As such, it has not been intended to replace the existing recovery plan (U.S. Fish and Wildlife Service, 2014); instead, it is meant to be a more detailed assessment of those actions that are clearly the responsibility of the USACE and geographically limited to the Missouri River.

The Missouri River EA started in the summer of 2013 with commission of three interacting teams for hydrogeomorphology, nest shorebirds, and the pallid sturgeon. The teams were asked to follow the general guidance for steps in an EA:

- collection of reliable scientific information,

- critical assessment and synthesis of available data and analyses, and

- analysis of the effects of actions on listed species and their habitats.

In this process, the pallid sturgeon EA team developed a series of four reports to serve as a foundation of knowledge. The first report (Jacobson, Annis, and others, 2015) is a compilation and assessment of available information and modeling resources that can be used to understand historical and future changes of pallid sturgeon populations. The second report (Jacobson,

${ }^{2}$ The Lower Missouri River has been defined as the sections downstream from Gavins Point Dam to the confluence with the Mississippi River (Jacobson and others, 2010). 
Parsley, and others, 2015) describes conceptual ecological models (CEMs) developed to document and illustrate a global set of driver-stressor-response ecological relations for Missouri River pallid sturgeon. The CEMs were developed through workshops that included sturgeon and river experts from throughout the Missouri River basin. The third report (Jacobson, Parsley, and others, 2016) documents the process of filtering the global set of hundreds of hypotheses that emerged from the CEMs. The EA used expert-opinion surveys to formulate and filter hypotheses, ending with an initial 21 working management hypotheses. The fourth report (Jacobson, Annis, and others, 2016) serves as a capstone and assesses the 21 working management hypotheses to document existing knowledge and to explore potential actions.

Hypotheses related to carrying capacity of segments of the Missouri River, resulting bioenergetic conditions and fish condition, and consequent reproductive potential (measured as fecundity, years to sexual maturity, years between reproductive events) were considered in the CEMs and hypotheses-filtering processes (Jacobson, Parsley, and others, 2015; Jacobson, Annis, and others, 2016); however, when the CEM and hypotheses-filtering processes took place in 2013 and 2014, existing information and expert opinion did not rank these hypotheses high enough to qualify within the top 21. Subsequently, new information about pallid sturgeon condition on the Lower Missouri River has emerged.

Throughout the EA and during development of the Missouri River Science and Adaptive Management plan (MRSAMP), concerns have been raised about how to ensure that the original 21 hypotheses do not become frozen as the sole focus of assessment. Concerns have included how to ensure that decision points are defined to determine when hypotheses can be abandoned and when new ones need to be developed, how to verify information using peer and technical reviews to ensure it is supportive of decision making, and how to define a science process that is effectively focused on decision-relevant hypotheses yet flexible and broad enough to anticipate surprises. The AM programs are particularly challenged where rapid scientific progress continually brings new information, such as the pallid sturgeon declining condition, to the AM process.

\section{Purpose and Scope}

The first purpose of this report is to evaluate the strength of evidence that pallid sturgeon condition is in decline in the Missouri River and to evaluate hypotheses that may explain such a trend. The second purpose is to serve as a pilot to test how new information may be accommodated in the MRRP AM process.

A robust, systematic, and repeatable evaluation process for new information has been considered necessary because new management actions could incur millions of dollars in recovery costs. The MRRP's need for review of scientific information extends beyond accepting results of peer review from agencies or scientific journals because criteria used by those institutions do not necessarily support decision-making of the MRRP. Criteria used by science journals may put emphasis on quality of the statistical analysis, novelty of the results, and (or) general applicability to the scientific field without addressing relevance to decisions faced by the MRRP.

\section{Charge to the Committee to Evaluate Declining Pallid Sturgeon Condition}

Following review and acceptance of the fish condition issue paper, MRRP science leads from the USACE and FWS issued a charge to the standing EA team to assess the new information. The expectation was for the EA team to use at least one representative from the 
requesting institution (NGPC) and an appropriate subset of the EA team to make up the issue team (hereafter referred to as team). For the fish-condition issue, the charge included the following two areas of focus:

1. Is there evidence that pallid sturgeon in the Lower Missouri River are in poor and (or) declining condition? What is the level of uncertainty in the conclusions?

2. What is the likely cause of the poor condition? What is the level of uncertainty in the conclusion?

The charge further asked for well-defined conclusions and associated recommendations, including, but not limited to, the following:

1. The issue lacks merit so no further work recommended.

2. Lack of sufficient data and (or) metrics preclude analysis or provide inconclusive results.

3. The issue has merit but there is too much uncertainty to recommend action. To reduce uncertainty, it is recommended that additional science efforts are needed.

4. The problem and cause are clear enough to recommend remedial action, including all recommended actions (even those that may be outside USACE's purview) as well as the confidence level that actions will produce the desired result.

\section{Missouri River Recovery Context}

Potential declining fish condition in the Missouri River takes place within the context of prevailing management actions and a dynamic river system. Although fish condition may be an issue elsewhere on the Missouri River, the charge is for the Lower Missouri River, downstream from Gavins Point Dam, South Dakota, and extending to the confluence with the Mississippi River at St. Louis, Mo. (fig. 1). The dominant management actions for pallid sturgeon on these river segments since the 2003 biological opinion (U.S. Fish and Wildlife Service, 2003) have been

- population augmentation to increase and maintain the pallid sturgeon as an interim measure until wild recruitment can be established;

- implementation of spring flow pulses (spring rises) from releases from Gavins Point Dam to provide spawning cues for reproductive adults and dispersal conditions for free embryos; and

- channel reconfigurations to increase diversity of channel-marginal habitats, with emphasis on habitats that would support rearing of age- 0 pallid sturgeon (shallow water habitat [SWH]).

More than 175,000 pallid sturgeon have been stocked in the Lower Missouri River between 1994 and 2015 (Huenemann, 2016). These fish were variably stocked as fingerlings (age-0), yearlings (age-1) and older (age-2+). Although stocking has followed prevailing best management practices (BMPs) during this time period, the BMPs have been evolving from an emphasis on total numbers stocked to an emphasis on maintaining natural genetic diversity.

In parallel with stocking, the USACE has implemented numerous channel reconfiguration projects to replace some of the habitat diversity lost due to channelization of the Missouri River system. The guiding goal for channel reconfiguration has been the concept of $\mathrm{SWH}$, which was initially defined as being $0-1.5$ meters $(\mathrm{m})$ deep and with current velocity 0 0.6 meters per second $(\mathrm{m} / \mathrm{s})$ based on documentation that these slow, shallow habitats were historically more prevalent prior to channelization (U.S. Fish and Wildlife Service, 2000, 2003). Although the SWH criteria have been criticized for lacking specific linkages to life-history needs 
of the pallid sturgeon (National Research Council, 2011), the argument for needing more of these habitats is supported by the biological understanding that age- 0 fish need rearing conditions suitable for growth and by historical documentation that these habitats were present in much greater abundance (Jacobson and Galat, 2006). Construction of SWH was thought to provide a food base for age- 0 sturgeon as well as more supportive bioenergetic conditions for foraging.

Channel reconfigurations have been intended to mitigate for channelization and habitat loss associated with the Missouri River Bank Stabilization and Navigation Program (BSNP). The BSNP (and previous channelization programs) resulted in channel simplification and loss of 404 square kilometers $\left(\mathrm{km}^{2}\right)$ of aquatic and sandbar habitat (U.S. Army Corps of Engineers, 2003). Although the BSNP was determined to be complete in 1986, there have been questions about ongoing geomorphic adjustments within the Missouri River system that may be interacting with BSNP structures and resulting in continued changes to the biophysical capacity of the Lower Missouri River. Among these are long-term (multidecadal) adjustments to sediment deficits downstream from the main-stem reservoir system after closure in the 1950s and ongoing effects of instream aggregate mining in the downstream 500 miles $^{3}$ of the river (Jacobson and others, 2009). The effects of large floods that might serve to accelerate geomorphic adjustments, or perhaps surpass thresholds beyond which geomorphic recovery will not occur, have modified the multidecadal trends. Large floods have affected different parts of the Lower Missouri River at different times. Notable floods occurred in 1993 (mostly downstream from St. Joseph, Mo.), 1997 (mostly between Gavins Point Dam and St. Joseph, Mo.), and 2011, with the highest annual runoff on record, which affected the entire river downstream from Gavins Point Dam but with diminishing effect downstream from Kansas City, Mo. (fig. 3).

Although population augmentation, spring rises, and channel reconfigurations have been implemented during the last decade, the Lower Missouri River has also been affected by multiple other environmental factors that may affect carrying capacity of the river and pallid sturgeon condition. Agricultural, municipal, and industrial runoff have certainly varied during this time, but these water quality conditions and how they may have affected the Missouri River food web have not been quantified. Perhaps more importantly, the river fish community may have been altered by invasive species. The principal concern has been Asian carps (silver carp, Hypophthalmichthys molitrix, and bighead carp, Hypophthalmichthys nobilis), which are now present throughout the Lower Missouri River. Other organisms such as zebra mussels (Dreissena polymorpha) are also present. Understanding of the potential role of invasive species is limited by lack of specific Missouri River data on populations and processes, but evidence from other river systems raises concerns that species like Asian carps that feed on phytoplankton and zooplankton have the potential to diminish the base of the food web, which is an effect that could propagate to top predators like pallid sturgeon (Pendleton and others, 2017).

${ }^{3}$ A note on units: we use cubic feet per second ( $\mathrm{ft}^{3} / \mathrm{s}$ ) and feet $(\mathrm{ft})$ for units of river discharge, stage, or bed elevation to facilitate communication with management agencies, which use these units customarily for planning and assessments. We use metric units otherwise. 

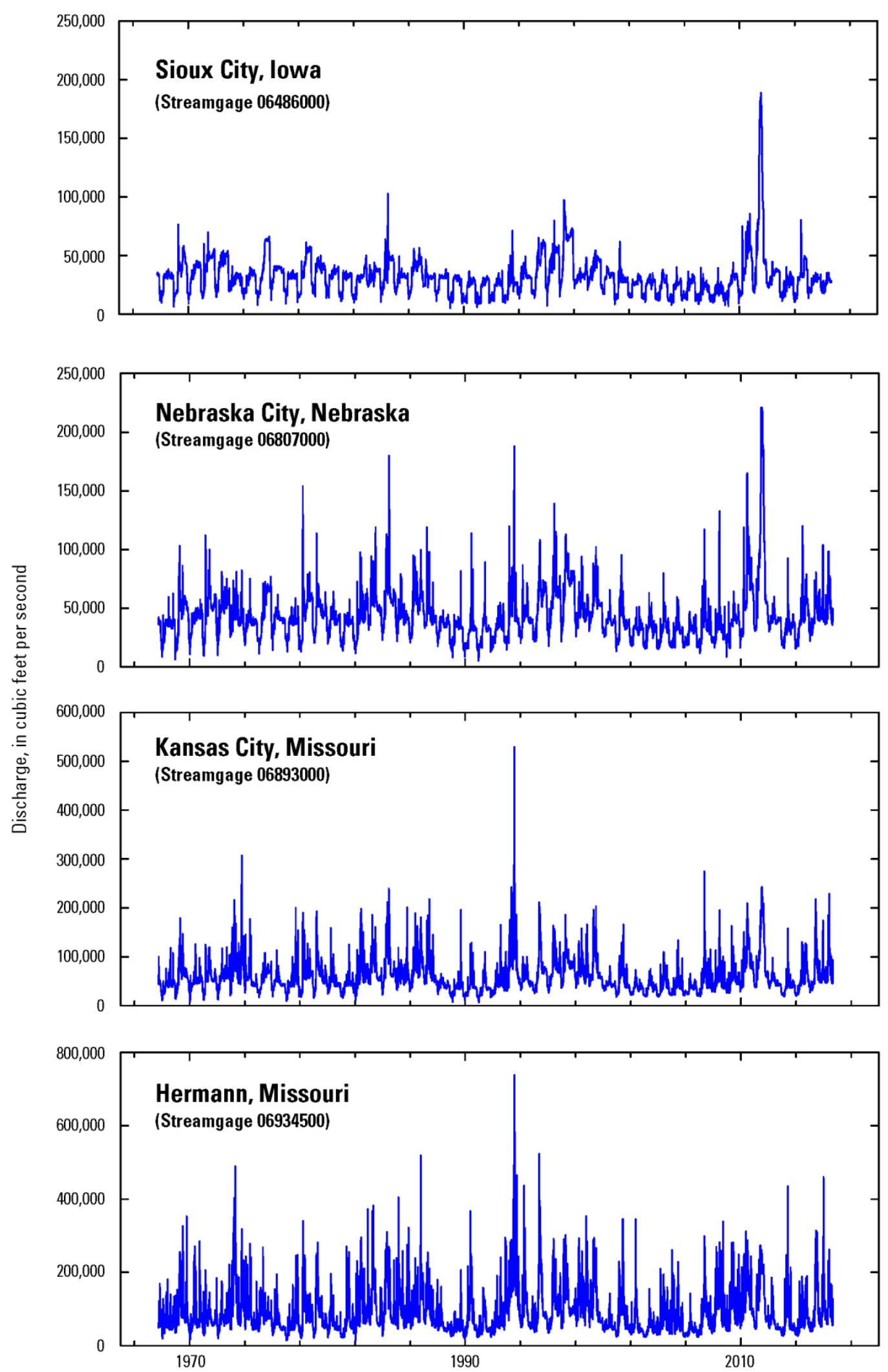

Figure 3. Hydrographs of selected Lower Missouri River streamflow-gaging stations showing the history of recent large flood events. Data availability: U.S. Geological Survey (2016). 


\section{Question 1-Is Pallid Sturgeon Condition Declining?}

The first question posed to the team was addressed by compiling all available data on pallid sturgeon condition and subjecting the data to several analyses for assessing condition and trends in condition. The objective of these analyses was to determine whether the conclusions about fish condition in the NGPC assessments (Steffensen and Mestl, 2016; Steffensen and others, 2016) remain accurate when using different sets of analytical procedures. In particular, our approach looked at relative condition over different ranges of location, origin, size class, and year of capture to focus on characteristics of the pallid sturgeon population that might provide insight into the severity of, extent of, and cause for declining condition. We also looked at how individual fish differed from the reference population to provide an objective measure of when condition could be considered low.

\section{Compilation of Available Data}

Data for this assessment were obtained from two projects that support the MRRP: the Pallid Sturgeon Population Assessment Project (PSPAP) and the Habitat Assessment and Monitoring Project (HAMP). The PSPAP and the HAMP were developed to meet monitoring requirements for pallid sturgeon Reasonable and Prudent Alternative elements in the 2003 biological opinion for the Missouri River (U.S. Fish and Wildlife Service, 2003). The PSPAP data consist of standardized monitoring and targeted broodstock captures of pallid sturgeon. The geographic scope of the PSPAP (and associated data) encompasses the Missouri River from Fort Peck Dam, Montana, downstream to the headwaters of Lake Sakakawea; Fort Randall Dam, S. Dak., downstream to the headwaters of Lewis and Clark Lake; the Lower Missouri River from Gavins Point Dam to the confluence of the Missouri and Mississippi Rivers near St. Louis, Mo.; and the lower reach of the Kansas River (fig. 1). Fish and habitat data were collected within 12 Missouri River segments and several major tributaries that cover the geographic scope of the MRRP. Partial sampling started in 2003, with full implementation of standardized sampling in all the segments beginning in 2006.

The PSPAP uses a three-tiered hierarchical habitat classification system (macrohabitat, mesohabitat, and microhabitat) that allows for general and specific categorization for sampling to serve the needs of biological and physical data collection efforts. A "river bend" (bend) serves as the basic sampling unit (replicate) within each river segment. Within a segment, at least 25 percent of all bends are randomly selected and sampled in a year during standard sampling with a suite of sampling gears, which includes gill nets, trot lines, trammel nets, otter trawls, and minifyke nets. Multiple fish and habitat metrics are collected and recorded through the PSPAP. For each captured pallid sturgeon, fork length (snout to fork [FL], in millimeters), body weight (in grams), geographic location, marking (passive integrated transponder [PIT] tag, elastomer tag, scute removal), status (hatchery or wild origin), genetics, and physical habitat at capture location (for example, depth, turbidity, current velocity) are collected. In addition, some of these data are collected from a representative group of native Missouri River fishes that share similar life history characteristics with pallid sturgeon (for example, shovelnose sturgeon, Scaphirhynchus platorynchus) or that may serve as prey items (for example, sicklefin chub, Macrhybopsis meeki; sturgeon chub, Macrhybopsis gelida). The standardized PSPAP monitoring consists of random and non-random sampling within the sample design. Most of the pallid sturgeon were captured in March-May in the Lower Missouri River (58 percent) and August-October in the Upper Missouri River (67 percent). Broodstock sampling and data collection are non-random, and 
primarily occur in March-April in the Lower Missouri River and May-June in the Upper Missouri River. Less than $(<) 5$ percent of the Upper Missouri River catch is obtained through broodstock collection, whereas greater than ( $>$ ) 35 percent of the Lower Missouri River pallid sturgeon catch is collected during broodstock sampling. Data collection procedures for the PSPAP follow standardized protocols from Welker and Drobish (2016).

The HAMP was developed in 2004 to assess physical and biological responses to habitat modification in the channelized portion of the Lower Missouri River, downstream from Ponca, Nebraska, for targeted fish species including pallid sturgeon. Physical and biological (invertebrate and fish) data were collected through HAMP to evaluate how changes to river habitat influenced native populations of fish. Since 2012, HAMP efforts have been modified to focus on specific hypotheses relating shallow-water habitat to life-stage processes of larval and young-of-year pallid sturgeon (T. Gemeinhardt, U.S. Army Corps of Engineers, oral. commun., July 2017). HAMP and PSPAP collect similar biological and habitat data for pallid sturgeon; therefore, HAMP data collection follows the protocols (with some modifications) for PSPAP in Welker and Drobish (2016). Fewer pallid sturgeon have been collected through HAMP as compared to PSPAP.

The Pallid Sturgeon Population Assessment Project Database (PSPAP-D) is an Oracle relational database (ORD) that organizes tabular fish and habitat data collected through the PSPAP and several other projects. As of 2014, the entire database has been physically housed at the U.S. Army's Cold Regions Research and Engineering Laboratory in Hanover, New Hampshire. The quality assurance/quality control (QA/QC) requirements and data error limits are primarily met during data collection through limited choices and lookup values on hand-held field computers; however, other QA/QC checks are performed after the data are loaded into the ORD. The HAMP biological data collected from 2006 to 2012 are incorporated into the PSPAPD. Data collected since 2012 are housed with the HAMP manager, but HAMP follows QA/QC data protocols similar to those required for the PSPAP and PSPAP-D. Most of the pallid sturgeon data used for this assessment were PSPAP data obtained from the PSPAP-D.

A data request for all Missouri River pallid sturgeon records was made by the team to the data manager of the PSPAP-D on July 26, 2016. The current (2017) contact and data manager for the PSPAP-D is Coral Huber (Coral.J.Huber@usace.army.mil), who is also data manager for the MRRP. The team decided to evaluate pallid sturgeon condition from the Upper Missouri River as well as the Lower Missouri River for comparative purposes. A database of 12,472 records was received. The data were examined for completeness and accuracy. Observations were removed if they fit the following conditions:

1. Missing length or weight (138 removed)

2. Length or weight equal to 0 (1 removed)

3. Outliers: residuals for the $\ln ($ weight $) \sim \ln ($ length) relationship $<-1.5$ or $>1.5$ ( 7 removed)

4. Length $<200 \mathrm{~mm}(85$ removed)

5. Records judged as field, equipment, or transcription errors by expert opinion (12 removed)

Removal of these 243 records left 12,229 records for preliminary analysis.

\section{Data Analysis}

Our data analysis approach consists of two parts. The first is to revisit the original methodology of NGPC and the foundation of the Kn measurements to address the question of 
what is a skinny fish. The second is to use an analysis of covariance approach that avoids some of the pitfalls of $\mathrm{Kn}$ to assess factors related to poor fish condition.

\section{What is a Skinny Fish?}

The charge to the team was to assess whether pallid sturgeon in the Lower Missouri River were in "poor or declining condition." To begin to answer the question, one must first define condition and then assess what constitutes "poor" condition, or skinniness. Condition in fish is typically assessed using a length-weight relationship (LWR). The underlying biological assumption is that, for any given fish species, a fish of a certain length should have a certain weight, and that a fish at or above that weight is in better condition than a fish below that weight. Most condition LWRs conform to a power-law relation:

$$
W=a L^{b}
$$

where

W is weight,

$L \quad$ is length, and

$a$ and $b$ are coefficients.

Most researchers transform this relation for simplicity into a log-log relationship, which will plot out on a straight line.

Once an LWR curve has been derived for a fish species, any individuals caught subsequently are compared to the expected weight at length by dividing the observed weight by the expected (from the LWR) weight, which creates a unitless condition factor $(\mathrm{Kn})$ centered around 1.0. If the individual's weight is above the expected weight given its length, the Kn would be $>1.0$ and the fish is said to be in "good" condition relative to the population; if the Kn is $<1.0$ (the fish is below the expected weight), it is in "poor" condition relative to the population.

There are multiple methodologies for assessing fish condition. We used two separate methodologies: $\mathrm{Kn}$, because it has a historical and recent usage in pallid sturgeon, and an ANCOVA approach. By using two different LWRs, interpreted globally and individually, as well as the ANCOVA approach, we attempted to account for issues with methodology; if all five analytical methods were to yield similar results, we assumed that the results would be more supported than using any one methodology. For pallid sturgeon, Shuman and others (2011) generated a condition index (Shuman $\mathrm{Kn}$ ) using the formula $\mathrm{Kn}=$ observed weight/expected weight, where expected weight was estimated from the LWR:

$$
\log _{10}(\text { weight })=-6.2561+3.2932 \cdot \log _{10}(\text { fork length })
$$

The statistical fit to this relation has a coefficient of determination $\left(r^{2}\right)$ of 0.98 and $p$ value $<0.001$. The relation was estimated using lengths and weights of 2,268 pallid sturgeon collected from the Missouri River upstream from Fort Peck Lake to the confluence with the Mississippi River between 1998 and 2007. The 2,268 fish ranged from $116 \mathrm{~mm}$ FL to 1,640 mm FL. The LWR curve derived from Shuman Kn formula for lengths from 200 to 1,600 mm FL is shown in figure 4. 


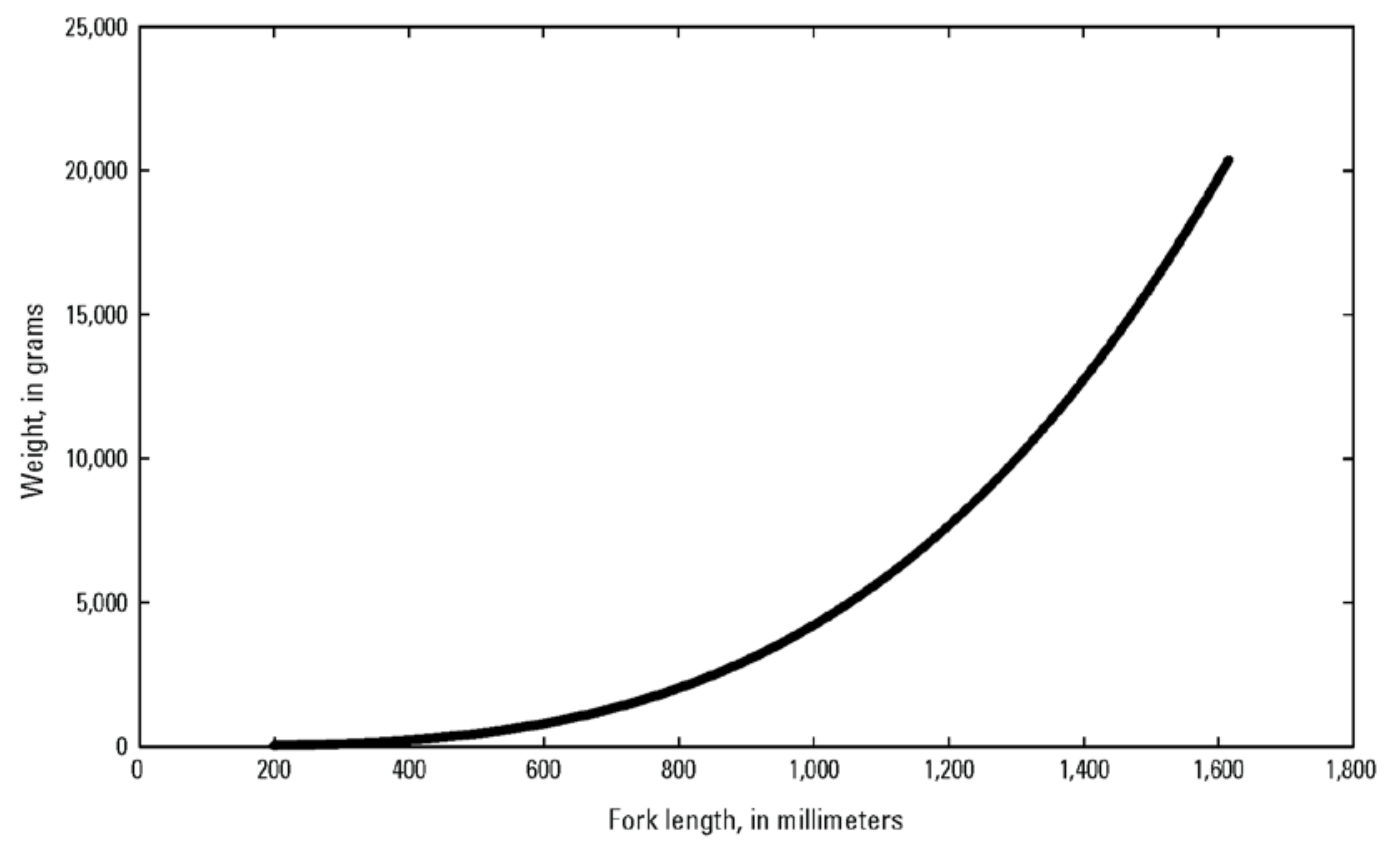

Figure 4. Shuman and others (2011) length-weight relation (LWR) used to calculate Shuman Kn, based on sturgeon capture from Fort Peck Lake to the confluence with the Mississippi River (1998-2007).

There are, however, methodological challenges with the derivation of $\mathrm{Kn}$ and the use of $\mathrm{Kn}$ to index condition. The Kn method relies on identification of a reference LWR and care should be taken to identify a reference population that shares the genotype and phenotype of the comparison population. Shuman and others (2011) did not note statistically significant differences among geographically divergent populations; however, the length distributions presented indicate substantial differences in size structure among the sampled regions. The longest fish sampled in the lower basin ${ }^{4}$ is $1,194 \mathrm{~mm} \mathrm{FL}$, whereas the longest fish sampled in the upper basin ${ }^{5}$ is $1,628 \mathrm{~mm}$ FL. Moreover, recent genetics studies have yielded insights that genetic variation over the geographic range is significant (Schrey and Heist, 2007), so variation in phenotype is possible. We use the Shuman and others (2011) LWR for the first part of our analysis but caution that the geographically averaged reference curve may obscure some Kn trends.

For the second part of our analysis, we derived a new Kn relationship using all the records in the curated database and only fitting the curve to fish between 200 and 1,200 mm FL (fig. 5), which avoids issues based on data selection and potential biases associated with including large, upper-river reproductive females. However, this methodology may possibly obscure any recent depression in condition; by including any low-condition fish in the data, the average expected weight would be lowered.

The new Kn formulation (henceforth referred to as "Alternative Kn") for Missouri River pallid sturgeon between 200 and 1,200 $\mathrm{mm}$ FL is shown in the following equation:

$$
\log _{10}(\text { weight })=-5.9205+3.1574 \cdot \log _{10} \text { (fork length) }
$$

\footnotetext{
${ }^{4}$ Segments of the Middle and Lower Missouri River and tributaries are referred to collectively as the lower basin; these constitute PSPAP segments 5-14. Note segment 12 is no longer used. ${ }^{5}$ The Upper Missouri River and Yellowstone River are referred to collectively as the upper basin; these constitute PSPAP segments 1-4.
} 
Population characteristics change over time, as well, so decisions need to be made about when a reference population is stable enough to be used for comparison. Shuman and others (2011) probably captured populations in a transient state that reflected the combination of wild and hatchery fish. Fish capture during the 1998-2007 timeframe likely included initial saturation with older wild fish, followed by oversampling with young hatchery fish that were released once population augmentation began in earnest. Other concerns are based on generic issues of scarcity; low-abundance animals, due to lack of competition for resources, may have feeding rates and condition factors that are not representative of what a normal, more-abundant population might have. The Alternative Kn formulation, because it includes all relevant fish, avoids decisions as to whether the population is representative. By selecting fish $<1,201 \mathrm{~mm}$ FL, the formulation tracks the expected weight of mid-size to large fish better than the Shuman Kn formula, which was forced upward to fit extremely heavy and long upper-basin reproductive females. This upward forcing causes a divergence between the Shuman and Alternative models at lengths above $600 \mathrm{~mm}$ FL. As the stocked pallid sturgeon have grown, the number of individuals sampled in the divergence interval (that is, $>600 \mathrm{~mm}$ ) has increased, thereby creating an artificial drop in condition (that is, the difference between Shuman Kn and the Alternative $\mathrm{Kn}$ ), due to a poor fit of the initial population.

Specific variation from reference populations may arise when fish approach reproductive status. As sturgeon mature, they begin to add more weight relative to length, especially in females. If large, reproductive females are underrepresented in the reference LWR, the LWR will tend to underestimate their expected weight and $\mathrm{Kn}$. Thus, large, reproductive females will be biased high (that is, $\mathrm{Kn}>1$ ). To avoid variability associated with large, reproductive females, the Alternative formulation is fit to fish $<1,200 \mathrm{~mm}$ in length (fig. 6).

Another issue relates to evaluation of post-spawn females: is a fish that has just reproduced truly in physiologically "worse" condition than it was immediately before reproducing? A large pallid sturgeon female might decrease 10-15 percent or more in body weight over several hours in a successful spawn; in other sturgeon species, the mass of eggs may reach 20 percent of body weight. Thus, the Kn of a spawned fish could decline drastically, whereas the fish would, in reality, be just as healthy as it was before spawning. Biases by postspawn fish are minimized in our analysis because most (94 percent) of the spawning-sized fish are captured outside of this post-spawn period.

Finally, we note that relative condition indexed by Kn has not been conclusively linked to population-relevant condition like reproductive failure or mortality and has been shown to be non-correlated to some metrics of spawning success (Steffensen and Mestl, 2016). That is, although low values of Kn may be considered a matter of concern, there are no guidelines to document how low $\mathrm{Kn}$ has to go to have biological consequences.

To evaluate concerns with variability in $\mathrm{Kn}$ that might arise from errors in weighing or measuring fish, we explored variation derived from short-period recaptures. Due to either directed recapture efforts (for example, to assess reproduction) or repeated sampling within a region, there are multiple recaptures of fish within a short timeframe. As a means of checking for either equipment error, between-sampler variation, or other error sources, we examined the variation in the Shuman Kn between recaptures with intervals between 0 (same day recapture) and 2 days. Out of 2,225 recaptures, there were 220 recaptures of fish within 2 days: 49 sameday, 119 next-day, and 52 second-day. The range of Kn variation during this time period was 0.69 , ranging from a loss of 0.31 to a gain of 0.37 . The mean difference was 0.002 , with a standard deviation of 0.06 (fig. 7). Interestingly, all same-day recaptures resulted in an increase 


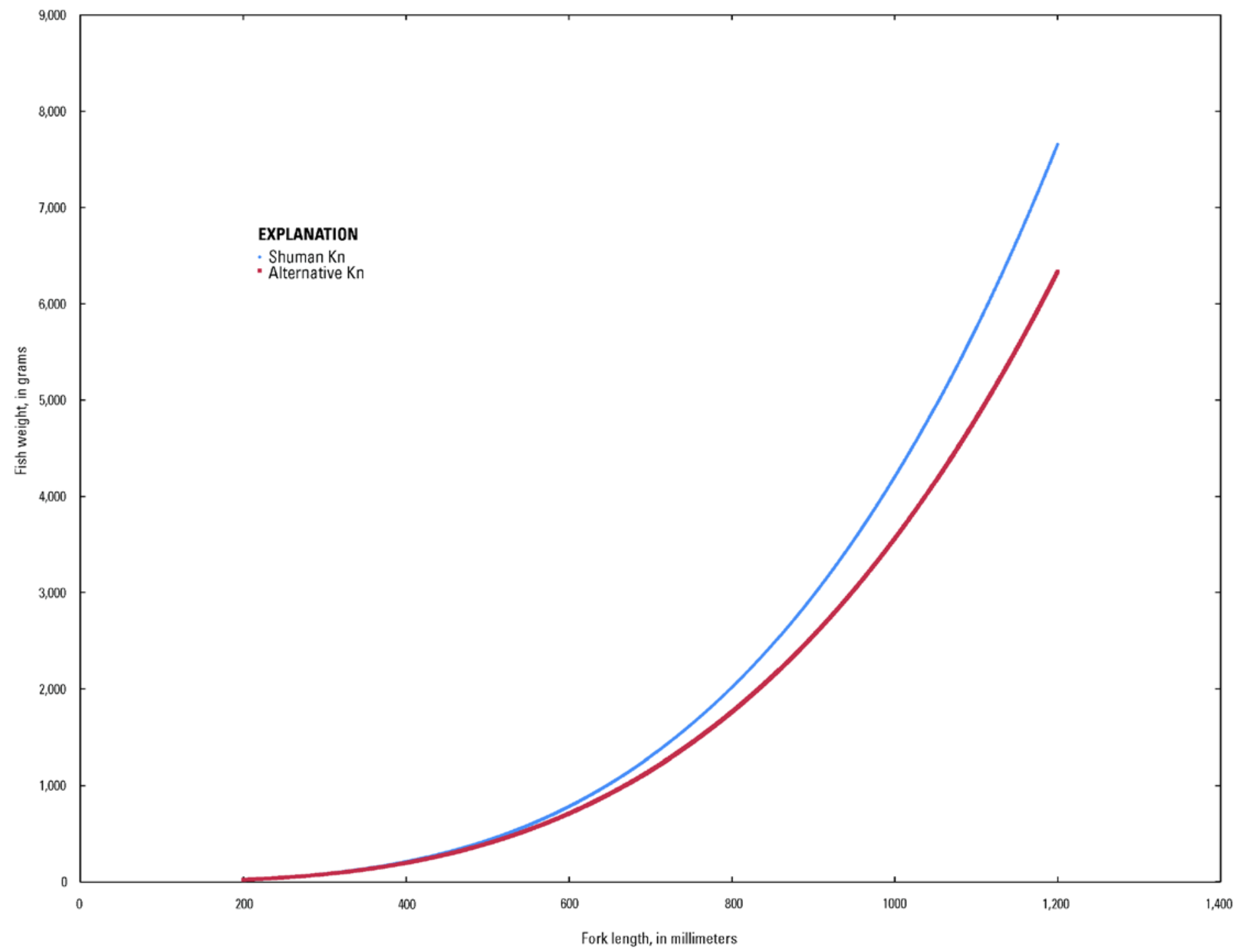

Figure 5. Shuman and alternative length-weight relationship (LWR), used for calculating Shuman Kn and Alternative Kn. Data availability: Welker and Drobish (2016). 


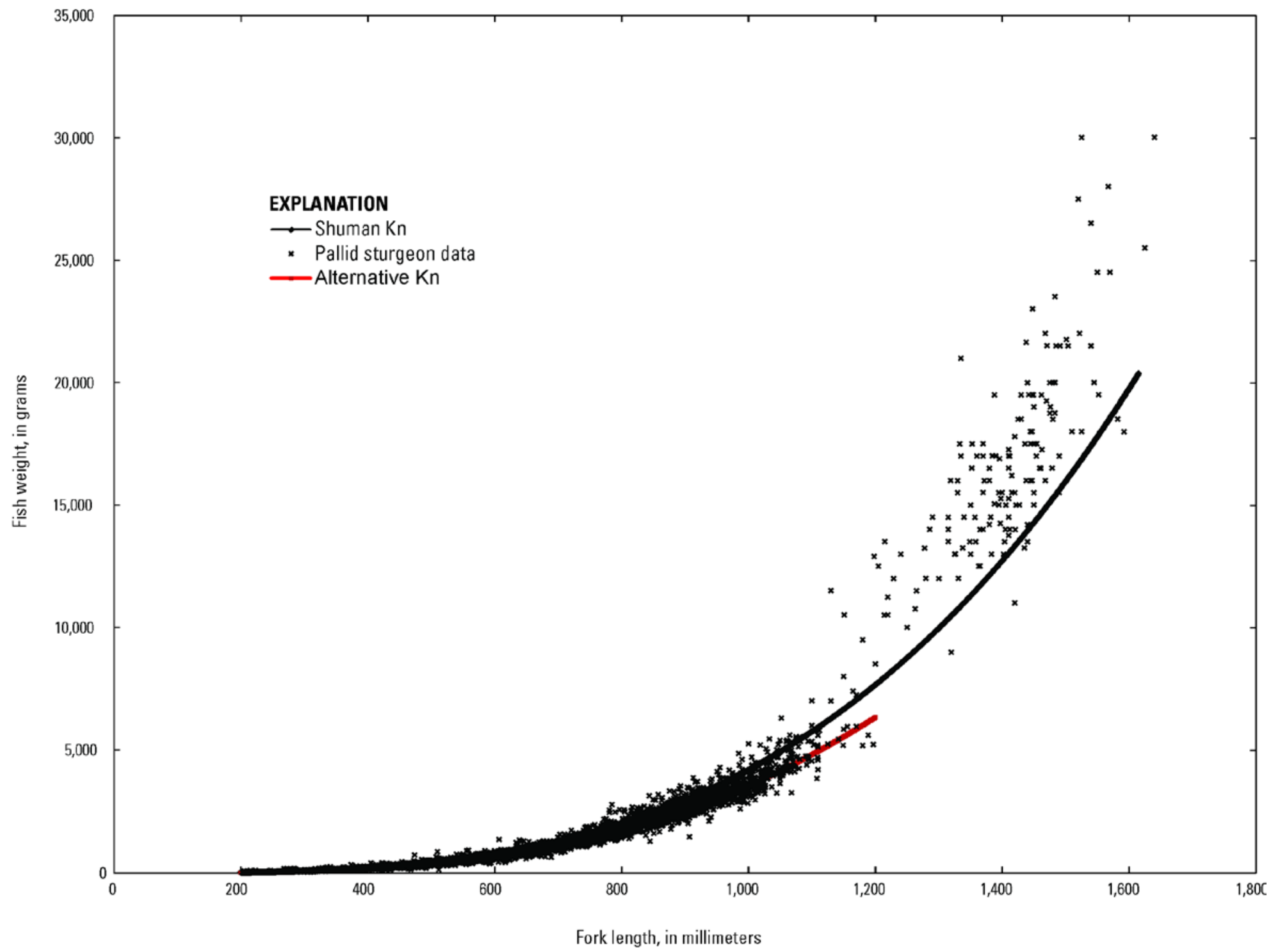

Figure 6. Shuman length-weight relationship (LWR), the Alternative Kn LWR, and all length-weight data from the Missouri River. Data availability: Welker and Drobish (2016). 
in $\mathrm{Kn}$, whereas next-day and second-day recaptures resulted in a more balanced distribution of Kn difference. If the assumption is made that meaningful changes in condition would not occur on a 0 to 2 day timeframe, then differences in Kn less than plus or minus $( \pm) 0.06$ must be regarded as random measurement error in either length or weight.

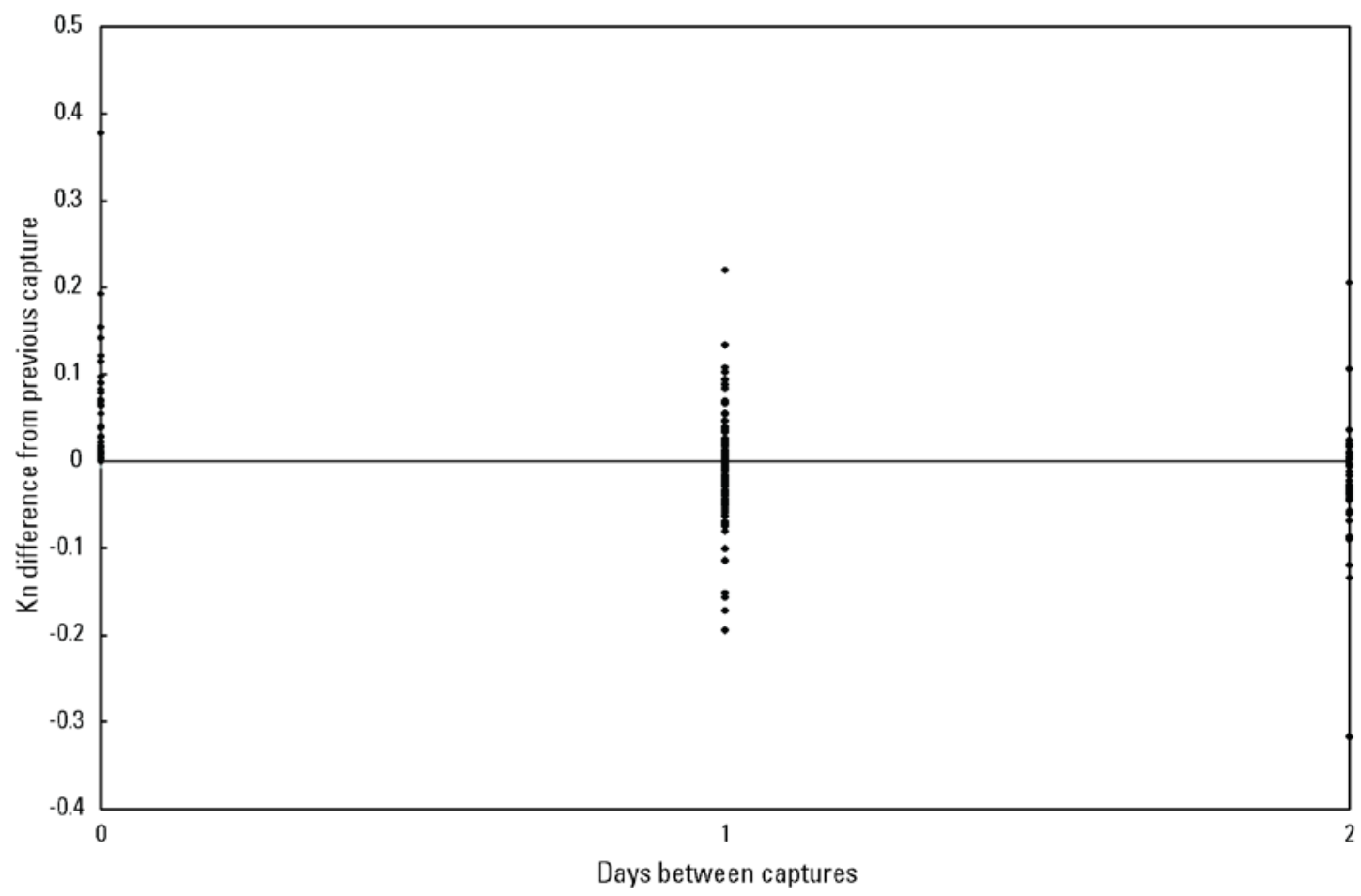

Figure 7. Shuman Kn variation of pallid sturgeon from same-day to second-day recapture. Data availability: Welker and Drobish (2016).

Although we have methodological concerns with $\mathrm{Kn}$ as an index, the first part of our analysis proceeded with the Shuman Kn formulation because it is a widely used descriptive metric for the species and was used in previous analyses (refer to the "Discussion-Future Directions in Assessing Pallid Sturgeon Condition" section for more direct metrics of fish health that might be used in the future). For the remainder of the analysis, we fit an alternative LWR and an ANCOVA model. We then reduced bias in the evaluation by limiting the analysis to a size range between 200 and 1,200 $\mathrm{mm}$ FL, which has minimal effect for assessing a reported decline in condition because most of the larger fish are from the upper basin, whereas most of the concern has been from the lower basin. Truncating the dataset at 1,200 $\mathrm{mm}$ FL resulted in the removal of 156 records, leaving 12,073 records for analysis. The data are fairly evenly split between the upper basin (6,271 records) and the lower basin (5,802 records), but the data are not as evenly divided over time (table 1). Capture effort started out slowly, with only 60 records from 2003. As effort increased and the number of stocked fish increased, the number of records increased, with 2009 through 2015 having more than 1,200 records annually. The number of captures of hatchery stocked fish compared to wild-origin fish is shown in table 2; this is expanded in table 3 to include year of capture, size class, and location. As of July 26, 2016, there 
were 420 records from 2016 in the dataset. Not all segments (fig. 1) are represented equally; segments 3, 4, 7, and 9 combine for 66.2 percent of the data (7,995 records), whereas segments $1,11,21,22,23,24,28$, and 52 represent only 0.6 percent of the data ( 76 records); segments $21-$ 52 are designations for tributaries that are rarely sampled. Only the mainstem segments are shown on figure 1 .

Table 1. Distribution of records of pallid sturgeon by basin, segment and year.

[Data availability: Welker and Drobish (2016).]

\begin{tabular}{|c|c|c|c|c|c|c|c|c|c|c|c|c|c|c|c|}
\hline \multirow{2}{*}{$\begin{array}{c}\text { River } \\
\text { segment }\end{array}$} & \multicolumn{14}{|c|}{ Year } & \multirow{2}{*}{$\begin{array}{c}\text { Segment } \\
\text { totals }\end{array}$} \\
\hline & 2003 & 2004 & 2005 & 2006 & 2007 & 2008 & 2009 & 2010 & 2011 & 2012 & 2013 & 2014 & 2015 & 2016 & \\
\hline \multicolumn{16}{|c|}{ Upper basin } \\
\hline 1 & - & - & - & - & - & - & - & - & - & - & - & - & 1 & - & 1 \\
\hline 2 & - & - & - & 14 & 20 & 16 & 33 & 40 & 71 & 166 & 101 & 123 & 112 & 18 & 714 \\
\hline 3 & - & - & - & 38 & 82 & 122 & 175 & 168 & 212 & 251 & 258 & 165 & 90 & 9 & 1,570 \\
\hline 4 & - & - & 22 & 23 & 26 & 75 & 135 & 709 & 232 & 298 & 326 & 435 & 435 & 26 & 2,742 \\
\hline 5 & 41 & 22 & 25 & 15 & 37 & 14 & 49 & 59 & 60 & 42 & 53 & 18 & 12 & 12 & 459 \\
\hline 6 & 9 & 6 & 19 & 35 & 65 & 87 & 128 & 89 & 19 & 53 & 93 & 48 & 34 & 46 & 731 \\
\hline 21 & - & - & - & - & - & - & - & 2 & 1 & - & - & - & - & - & 3 \\
\hline 22 & - & - & 2 & 1 & 14 & - & 2 & 1 & - & 1 & - & 1 & - & - & 22 \\
\hline 23 & - & - & - & - & - & 2 & 1 & - & - & - & - & - & - & - & 3 \\
\hline 52 & - & - & - & - & - & - & - & - & 26 & - & - & - & - & - & 26 \\
\hline $\begin{array}{c}\text { Annual } \\
\text { totals }\end{array}$ & 50 & 28 & 68 & 126 & 244 & 316 & 523 & 1,068 & 621 & 811 & 831 & 790 & 684 & 111 & 6,271 \\
\hline \multicolumn{16}{|c|}{ Lower basin } \\
\hline 7 & - & - & 1 & 9 & 82 & 68 & 48 & 198 & 122 & 347 & 184 & 82 & 22 & 20 & 1,183 \\
\hline 8 & - & - & 13 & 17 & 34 & 103 & 123 & 83 & 71 & 58 & 84 & 95 & 124 & 49 & 854 \\
\hline 9 & 3 & 10 & 12 & 31 & 31 & 235 & 307 & 249 & 287 & 168 & 247 & 320 & 375 & 225 & 2,500 \\
\hline 10 & - & - & 4 & 11 & 9 & 47 & 109 & 55 & 40 & 46 & 48 & 96 & 18 & 14 & 497 \\
\hline 11 & - & - & - & - & 1 & - & 4 & 7 & 3 & 1 & - & 1 & 1 & 1 & 19 \\
\hline 13 & 4 & 12 & 19 & 6 & 34 & 71 & 67 & 41 & 67 & 35 & 44 & 32 & 64 & - & 496 \\
\hline 14 & 3 & 3 & 10 & 9 & 19 & 22 & 32 & 22 & 28 & 35 & 19 & 14 & 35 & - & 251 \\
\hline 24 & - & - & - & - & - & - & - & 1 & - & - & - & - & - & - & 1 \\
\hline 28 & - & - & - & - & 1 & - & - & - & - & - & - & - & - & - & 1 \\
\hline $\begin{array}{c}\text { Annual } \\
\text { totals }\end{array}$ & 10 & 25 & 59 & 83 & 211 & 546 & 690 & 656 & 618 & 690 & 626 & 640 & 639 & 309 & 5,802 \\
\hline $\begin{array}{l}\text { Grand } \\
\text { total }\end{array}$ & 60 & 53 & 127 & 209 & 455 & 862 & 1,213 & 1,724 & 1,239 & 1,501 & 1,457 & 1,430 & 1,323 & 420 & 12,073 \\
\hline
\end{tabular}


Table 2. Count of hatchery origin compared with wild-origin pallid sturgeon, by year.

[Data availability: Welker and Drobish (2016).]

\begin{tabular}{cccc}
\hline Year & Hatchery & Wild & Annual total \\
\hline $\mathbf{2 0 0 3}$ & 45 & 15 & 60 \\
$\mathbf{2 0 0 4}$ & 35 & 18 & 53 \\
$\mathbf{2 0 0 5}$ & 96 & 31 & 127 \\
$\mathbf{2 0 0 6}$ & 159 & 50 & 209 \\
$\mathbf{2 0 0 7}$ & 391 & 64 & 455 \\
$\mathbf{2 0 0 8}$ & 622 & 240 & 862 \\
$\mathbf{2 0 0 9}$ & 960 & 253 & 1,213 \\
$\mathbf{2 0 1 0}$ & 1,513 & 211 & 1,724 \\
$\mathbf{2 0 1 1}$ & 1,056 & 183 & 1,239 \\
$\mathbf{2 0 1 2}$ & 1,317 & 184 & 1,501 \\
$\mathbf{2 0 1 3}$ & 1,198 & 259 & 1,457 \\
$\mathbf{2 0 1 4}$ & 1,189 & 241 & 1,430 \\
$\mathbf{2 0 1 5}$ & 1,084 & 239 & 1,323 \\
$\mathbf{2 0 1 6}$ & 313 & 107 & 420 \\
\hline Total & 9,978 & 2,095 & 12,073 \\
\hline
\end{tabular}

\section{Analysis of Covariance Methodology}

To address some of the shortcomings with Kn, we also fit an ANCOVA model to the data, which provides a complementary approach to the previous analyses of pallid sturgeon condition in the upper and lower Missouri River basins. Because condition is an index of observed weight relative to a predicted weight (based on length), modeling weight as a function of length using the model $\ln ($ Weight $)=\log (a)+b \cdot \ln ($ Length $)$ can be used to predict pallid sturgeon weight for a given length and provides a strong rationale for using this type of analytical approach. Predicted weights can then be compared between years to illustrate weight changes that should correspond to patterns in condition. Additionally, covariates like basin, year, and varying interactions of the two can be included in the model, providing flexibility in how weight is predicted for a given length and allowing for heterogeneity in the length-weight model parameters. Because condition is a function of weight, changes in model-predicted weight for a given length should correspond to changes in mean condition. If patterns in mean fish condition do not correspond to patterns of predicted weight, the discrepancy between patterns in mean condition and predicted weight should be evaluated because it indicates that mean fish condition may be misleading. The objectives of this complementary analysis were to:

1. Develop a model to evaluate the LWR among years and between the upper and lower Missouri River basins,

2. Use the model to predict weight for varying lengths of upper and lower Missouri River basin pallid sturgeon to compare between years and basin, 
Table 3A. Number of captures of pallid sturgeon by location, origin, size class, and year for $A$, upper basin and $B$, lower basin.

\begin{tabular}{|c|c|c|c|c|c|c|c|c|c|c|c|}
\hline \multicolumn{12}{|c|}{$\begin{array}{l}\text { [Grand total combines values from both basins. Data availability: Welker } \\
\text { and Drobish (2016).] }\end{array}$} \\
\hline \multirow{2}{*}{ Year } & \multicolumn{10}{|c|}{ Size class, $100 \mathrm{~mm}$ increments } & \multirow{2}{*}{ Annual tota } \\
\hline & 200 & 300 & 400 & 500 & 600 & 700 & 800 & 900 & 1,000 & $\overline{1,100}$ & \\
\hline \multicolumn{12}{|c|}{ Upper basin hatchery } \\
\hline 2003 & - & 4 & 5 & 6 & 25 & 2 & - & - & - & - & 42 \\
\hline 2004 & - & 5 & 2 & 6 & 7 & 1 & - & - & - & - & 21 \\
\hline 2005 & 4 & 29 & 14 & 7 & 4 & 1 & - & - & - & - & 59 \\
\hline 2006 & 33 & 36 & 17 & 13 & 6 & 4 & - & - & - & - & 109 \\
\hline 2007 & 63 & 81 & 43 & 26 & 5 & 7 & - & 1 & - & - & 226 \\
\hline 2008 & 81 & 87 & 42 & 38 & 20 & 7 & 7 & - & - & - & 282 \\
\hline 2009 & 106 & 181 & 90 & 51 & 29 & 11 & 12 & 1 & - & - & 481 \\
\hline 2010 & 146 & 462 & 204 & 120 & 48 & 23 & 15 & 4 & - & - & 1,022 \\
\hline 2011 & 41 & 304 & 139 & 57 & 23 & 13 & 4 & 1 & - & - & 582 \\
\hline 2012 & 30 & 356 & 259 & 48 & 39 & 29 & 6 & 5 & 4 & 1 & 777 \\
\hline 2013 & 5 & 313 & 272 & 52 & 43 & 26 & 21 & 5 & 3 & - & 740 \\
\hline 2014 & 3 & 223 & 334 & 58 & 33 & 35 & 32 & 12 & 5 & - & 735 \\
\hline 2015 & - & 146 & 350 & 59 & 26 & 19 & 25 & 7 & 8 & 4 & 644 \\
\hline 2016 & - & 13 & 18 & 33 & 23 & 7 & 6 & 1 & - & 1 & 102 \\
\hline Total & 512 & 2,240 & 1,789 & 574 & 331 & 185 & 128 & 37 & 20 & 6 & 5,822 \\
\hline \multicolumn{12}{|c|}{ Upper basin wild } \\
\hline 2003 & - & 1 & - & 1 & 6 & - & - & - & - & - & 8 \\
\hline 2004 & - & - & 1 & 3 & 2 & 1 & - & - & - & - & 7 \\
\hline 2005 & 1 & - & 2 & 3 & 2 & - & - & - & - & 1 & 9 \\
\hline 2006 & 1 & 1 & 5 & 8 & 1 & - & - & - & 1 & - & 17 \\
\hline 2007 & 2 & 1 & 9 & 6 & - & - & - & - & - & - & 18 \\
\hline 2008 & 6 & 9 & 1 & 10 & 7 & 1 & - & - & - & - & 34 \\
\hline 2009 & 9 & 7 & 3 & 10 & 10 & - & - & - & - & 3 & 42 \\
\hline 2010 & 10 & 10 & 4 & 12 & 8 & 1 & - & - & - & 1 & 46 \\
\hline 2011 & 3 & 14 & 6 & 7 & 3 & 5 & 1 & - & - & - & 39 \\
\hline 2012 & 1 & 7 & 11 & 1 & 6 & 2 & 2 & 2 & 1 & 1 & 34 \\
\hline 2013 & - & 13 & 11 & 5 & 31 & 17 & 7 & 2 & 4 & 1 & 91 \\
\hline 2014 & - & 3 & 16 & 2 & 8 & 10 & 8 & 3 & 2 & 3 & 55 \\
\hline 2015 & - & 3 & 11 & 9 & 5 & 5 & 1 & 1 & 2 & 3 & 40 \\
\hline 2016 & - & 1 & 1 & 3 & 1 & 3 & - & - & - & - & 9 \\
\hline Total & 33 & 70 & 81 & 80 & 90 & 45 & 19 & 8 & 10 & 13 & 449 \\
\hline
\end{tabular}


Table 3B. Number of captures of pallid sturgeon by location, origin, size class, and year for $A$, upper basin and $B$, lower basin.

[Grand total combines values from both basins. Data availability: Welker and Drobish (2016).]

\begin{tabular}{|c|c|c|c|c|c|c|c|c|c|c|c|}
\hline \multirow{2}{*}{ Year } & \multicolumn{10}{|c|}{ Size class, 100 mm increments } & \multirow{2}{*}{$\begin{array}{c}\text { Annual } \\
\text { total }\end{array}$} \\
\hline & 200 & 300 & 400 & 500 & 600 & 700 & 800 & 9001 & 1,000 & 1,100 & \\
\hline \multicolumn{12}{|c|}{ Lower basin hatchery } \\
\hline 2003 & - & 1 & - & 1 & 1 & - & - & - & - & - & 3 \\
\hline 2004 & 2 & 6 & 2 & 2 & 2 & - & - & - & - & - & 14 \\
\hline 2005 & 6 & 14 & 7 & 1 & 2 & 5 & - & 2 & - & - & 37 \\
\hline 2006 & 7 & 13 & 15 & 6 & 3 & 4 & 1 & 1 & - & - & 50 \\
\hline 2007 & 31 & 52 & 30 & 25 & 17 & 4 & 6 & - & - & - & 165 \\
\hline 2008 & 4 & 48 & 68 & 107 & 74 & 30 & 9 & - & - & - & 340 \\
\hline 2009 & 7 & 61 & 98 & 128 & 126 & 49 & 8 & 1 & 1 & - & 479 \\
\hline 2010 & 4 & 72 & 186 & 91 & 86 & 38 & 10 & 3 & 1 & - & 491 \\
\hline 2011 & 10 & 92 & 158 & 80 & 47 & 53 & 29 & 5 & - & - & 474 \\
\hline 2012 & 6 & 28 & 159 & 195 & 58 & 51 & 33 & 7 & 3 & - & 540 \\
\hline 2013 & 1 & 17 & 92 & 163 & 51 & 40 & 58 & 34 & 2 & - & 458 \\
\hline 2014 & 2 & 4 & 56 & 182 & 66 & 50 & 43 & 40 & 11 & - & 454 \\
\hline 2015 & 12 & 12 & 50 & 133 & 107 & 37 & 55 & 28 & 6 & - & 440 \\
\hline 2016 & 1 & 4 & 23 & 55 & 48 & 20 & 25 & 26 & 9 & - & 211 \\
\hline Total & 93 & 424 & 944 & 1,169 & 688 & 3812 & 277 & 147 & 33 & - & 4,156 \\
\hline \multicolumn{12}{|c|}{ Lower basin wild } \\
\hline 2003 & - & - & 1 & - & 1 & 1 & 3 & - & 1 & - & 7 \\
\hline 2004 & - & 1 & 1 & 1 & 1 & - & 3 & 1 & 3 & - & 11 \\
\hline 2005 & - & 2 & 4 & 2 & 3 & 6 & 1 & 2 & 2 & - & 22 \\
\hline 2006 & - & 3 & 5 & 5 & 4 & 4 & 6 & 5 & 1 & - & 33 \\
\hline 2007 & - & 1 & 8 & 13 & 6 & 4 & 7 & 5 & 2 & - & 46 \\
\hline 2008 & - & 2 & 19 & 46 & 42 & 30 & 28 & 28 & 11 & - & 206 \\
\hline 2009 & - & - & 15 & 34 & 50 & 43 & 31 & 24 & 13 & 1 & 211 \\
\hline 2010 & - & 1 & 16 & 32 & 33 & 35 & 27 & 14 & 6 & 1 & 165 \\
\hline 2011 & - & - & 11 & 13 & 19 & 25 & 35 & 32 & 9 & - & 144 \\
\hline 2012 & - & - & 4 & 29 & 33 & 25 & 38 & 16 & 5 & - & 150 \\
\hline 2013 & - & - & 3 & 15 & 24 & 32 & 41 & 39 & 13 & 1 & 168 \\
\hline 2014 & - & 5 & 4 & 15 & 21 & 26 & 46 & 51 & 15 & 3 & 186 \\
\hline 2015 & - & 2 & 2 & 10 & 23 & 22 & 50 & 58 & 29 & 3 & 199 \\
\hline 2016 & - & - & 1 & 1 & 6 & 11 & 30 & 34 & 13 & 2 & 98 \\
\hline Total & - & 17 & 94 & 216 & 266 & $264 ?$ & 346 & 309 & 123 & 11 & 1,646 \\
\hline $\begin{array}{c}\text { Grand } \\
\text { total }\end{array}$ & 638 & 2,751 & 2,908 & 2,039 & 1,375 & $875^{\circ}$ & 770 & 501 & 186 & 30 & 12,073 \\
\hline
\end{tabular}


3. Compare patterns of mean pallid sturgeon condition with corresponding patterns of predicted weight for varying pallid sturgeon lengths between years and between basins, and

4. Identify the cause of any discrepancies in patterns of mean condition and predicted weight.

We modeled pallid sturgeon weight as a function of length using the standard lengthweight model $\ln ($ Weight $)=\mathrm{a}+\mathrm{b} \cdot \ln ($ Length $)$. In addition to the effect of length on weight, we also included an effect of basin and year as categorical variables in this analysis. Additionally, 2- and 3-way interactions were included in the models evaluated. Ten possible models were evaluated representing the possible combinations of length, basin, year, 2-way interactions, and 3-way interactions. The model was fit to the pallid sturgeon length-weight data previously described by ordinary least squares. Length and weight values were natural log transformed before model fitting.

We used an information-theoretic approach to select the best approximating models among the 10 candidate models (Burnham and Anderson, 2002). First, a measure of model fit, Akaike's information criteria (AICc), was calculated for each fitted model. Then the delta of the AIC ( $\triangle \mathrm{AICc}$, calculated by subtracting model specific AICc from the minimum AICc). Modelspecific weight was calculated as $\exp (-0.5 \cdot \Delta \mathrm{AICc})$. A confidence model set was then identified as models whose cumulative weight was less than or equal to 0.95 (unitless proportion). The model or models retained in the confidence model were retained for statistical inference and to predict pallid sturgeon weight for a given length. The models retained in the confidence model set were used to predict pallid sturgeon weights for fish 200 to 1,600 $\mathrm{mm}$ in length by increments of $200 \mathrm{~mm}$. Predictions for lower-basin pallid sturgeon were constrained to length less than or equal to $1,200 \mathrm{~mm}$.

For fish condition to be comparable between basins and among years, condition should not vary with fish length (that is, there should not be allometric differences among fish (Cade and others, 2011); however, mean condition can be influenced by variable fish lengths in the catch, which would bias the mean condition calculation. To evaluate this we used predicted weights from the model retained in the confidence model set to predict weight for pallid sturgeon lengths 200 to $1,200 \mathrm{~mm}$ for the lower basin and 200 to $1,600 \mathrm{~mm}$ for the upper basin by increments of 1 and condition calculated as described by Shuman and others (2011) for each year and basin. Estimated condition was then plotted by length to visually assess the variation of condition with length between basins and among years.

Between-year comparisons of predicted weight were used to evaluate whether there was a decline in predicted weight for varying lower-basin pallid sturgeon lengths. Specifically, weight was predicted for 200 to $1,200 \mathrm{~mm}$ pallid sturgeon by increments of $200 \mathrm{~mm}$ and 95 -percent confidence intervals calculated for the model retained in the confidence model set. Within each length, differences in mean weight from 1 year to the next were estimated as the difference of the least squares means. We determined if length-adjusted mean weights were statistically different among years using planned post hoc comparisons of means. Statistical significance was determined using a $p$-value adjusted for multiple comparisons. Specifically, we made 24 comparisons and therefore the $p$-value was adjusted using a Bonferroni correction of $0.05 / 24=$ 0.002 to maintain an overall $\alpha=0.05$ (Bland and Altman, 1995). 


\section{Results of Kn Analyses}

The team viewed the Kn data as population data and individual data. The Shuman Kn and the Alternative Kn were calculated for all fish observations. The repeated short-term captures mentioned earlier were not excluded from the dataset because we have no way of knowing which (or if either) set of measurements is more accurate.

\section{Trends in $\mathrm{Kn}$}

When viewed as a population, there is a clear pattern over time, with some differences between the Shuman and Alternative formulations (figs. 8A, B, 9A, B), and with the Alternative formulation yielding higher and more stable Kn values. In 2003 and 2004, years with few captures, Kn values had wide confidence intervals for the upper and lower basins. From 2005 to 2012, Kn values in the upper basin showed little variation; the lower basin was characterized by a peak in 2007. Lower-basin values on average were lower than upper-basin values. The upperbasin values dropped in 2012 and 2013 but started to recover in 2014. Lower-basin Kn lagged the upper basin by a year, starting to drop in 2013 and continuing until 2015, before starting to recover in 2016.

By segment, the lower basin maintained the lower average Kn over time (fig. 10). Pallid sturgeon caught in segment 9 did not experience the 2007 peak, but did experience the 2012 bump (especially in Alternative Kn). Segment 9 decreased the furthest in the post-2012 drop, and has seen less of a 2016 increase.

Although the population-average Kn declined during the time period of sampling, it is also useful to examine the Kn values on an individual basis. One way to do this is to decide, based on a statistical analysis, how low the Kn value has to be for a fish to be in "poor" condition. Our approach was to look at the mean and standard deviation of the Kn values. If the values fit to a normal distribution, then fish with Kn values \pm 1 standard deviation from the mean would be considered to be normal fish, fish with Kn values below 1 standard deviation from the mean would be considered in low condition, and fish with values $>1$ standard deviation from the mean would be considered in robust condition. Kn values in the dataset show a good fit to a normal distribution (fig. 11).

In the 12,073 records, there were 20 extreme values for Kn between 1.9 and 3.5. These were fish between 200 and $424 \mathrm{~mm}$ FL with reported weights between 1.9 and 3.5 times the amount that Shuman's $\log / \log$ formulation predicted that they should have. These fish were dropped from the dataset because small but extremely robust fish either represented field measurement errors or were captured shortly after being stocked from the hatchery as fish are generally stocked at very high conditions. Descriptive statistics for the dataset are shown in table 4.

The mean and standard deviation $(0.94 \pm 0.13)$ for the edited dataset were used to denote low ( -3 to -1 standard deviations less than the mean; $\mathrm{Kn}<0.811)$, normal ( \pm 1 standard deviations from the mean; Kn 0.81-1.06), and robust fish (1 to 3 standard deviation greater than the mean; $\mathrm{Kn}>1.06)$. The number and percentage of observations in each class were tallied for the upper and lower basins by year (tables 5, 6). The same procedure was used for the Alternative formulation, with low Kn being below 0.88 and robust Kn being above 1.13. 


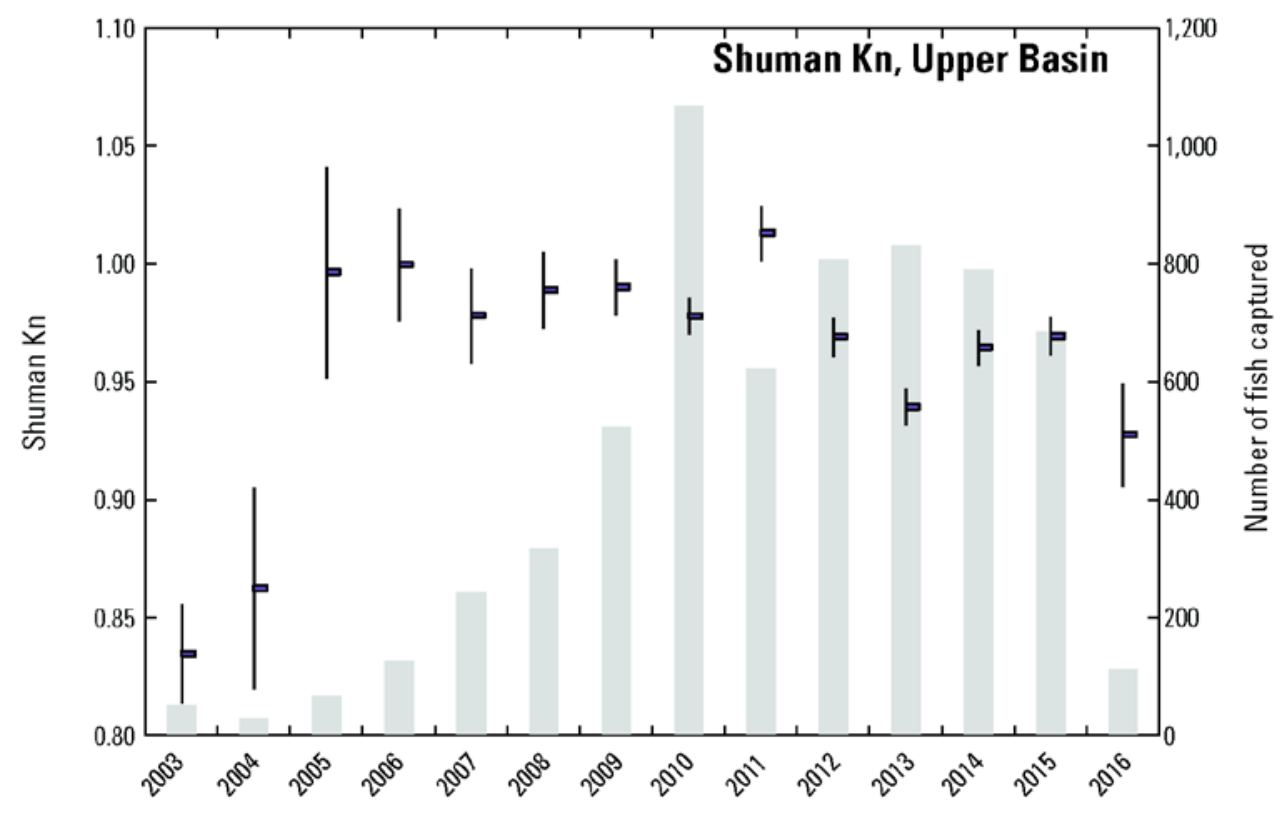

Figure 8A. Mean Shuman Kn values for the Missouri River basin since 2003. A, upper Missouri River basin. $B$, lower Missouri River basin. Gray bars are numbers of fish captured, black rectangles are mean $\mathrm{Kn}$ values, and vertical bars are plus or minus 95 -percent confidence intervals. Data availability: Welker and Drobish (2016).

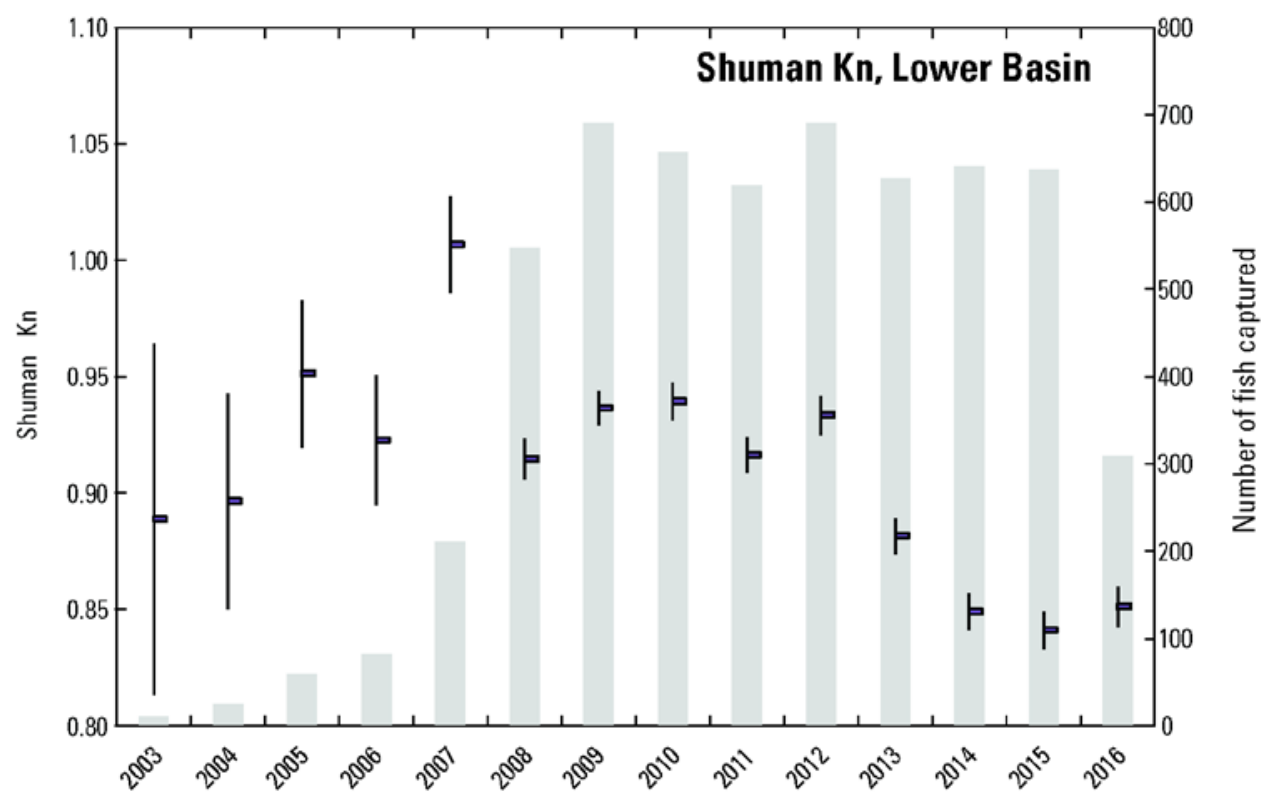

Figure 8B. Mean Shuman Kn values for the Missouri River basin since 2003. A, upper Missouri River basin. $B$, lower Missouri River basin. Gray bars are numbers of fish captured, black rectangles are mean $\mathrm{Kn}$ values, and vertical bars are plus or minus 95 -percent confidence intervals. Data availability: Welker and Drobish (2016). 


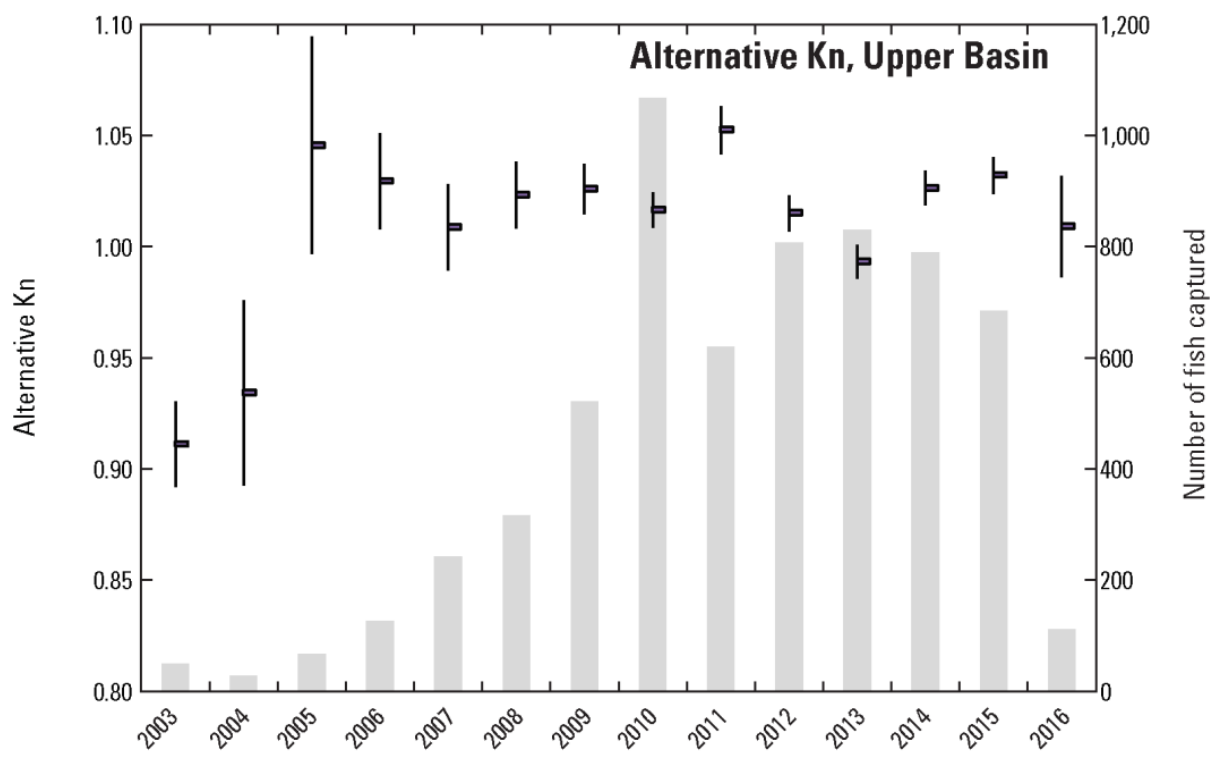

Figure 9A. Mean Alternative Kn values for the Missouri River basin since 2003. A, upper Missouri River basin. $B$, lower Missouri River basin.Gray bars are numbers of fish captured; black rectangles are mean $\mathrm{Kn}$ values and vertical bars are plus or minus 95 -percent confidence intervals. Data availability: Welker and Drobish (2016).

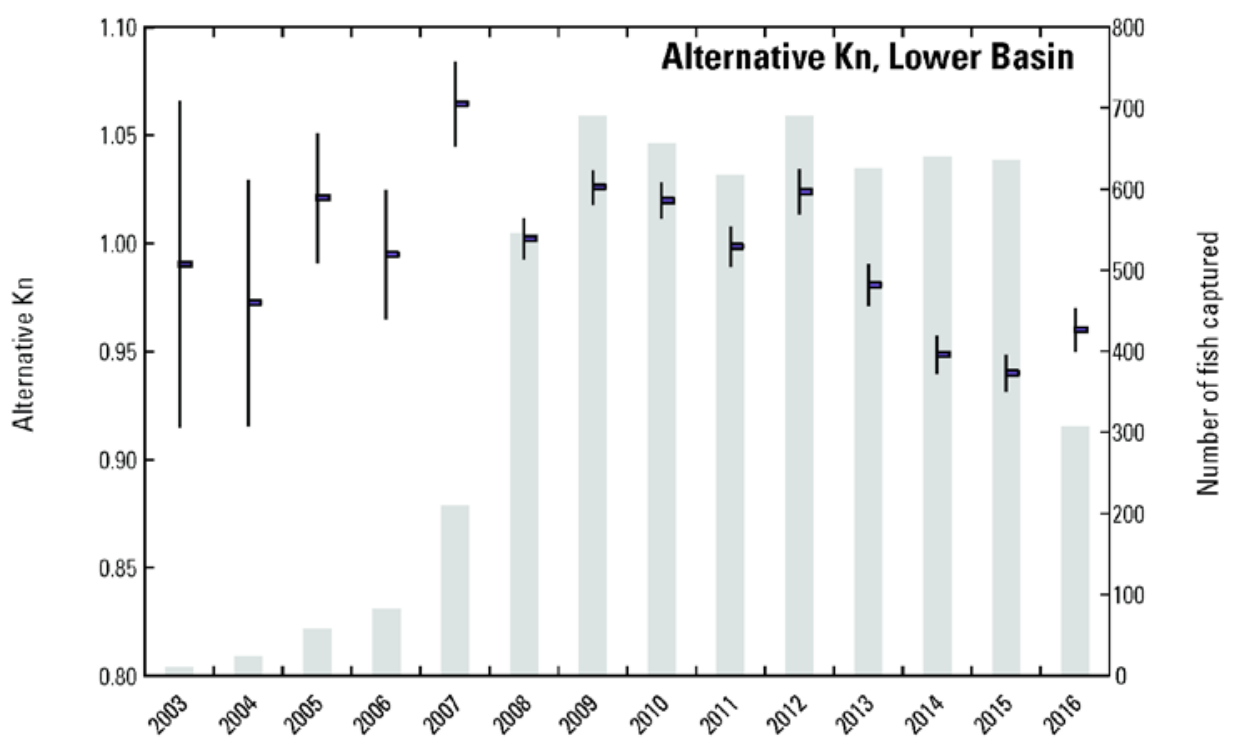

Figure 9B. Mean Alternative Kn values for the Missouri River basin since 2003. A, upper Missouri River basin. $B$, lower Missouri River basin.Gray bars are numbers of fish captured; black rectangles are mean Kn values and vertical bars are plus or minus 95 -percent confidence intervals. Data availability: Welker and Drobish (2016). 

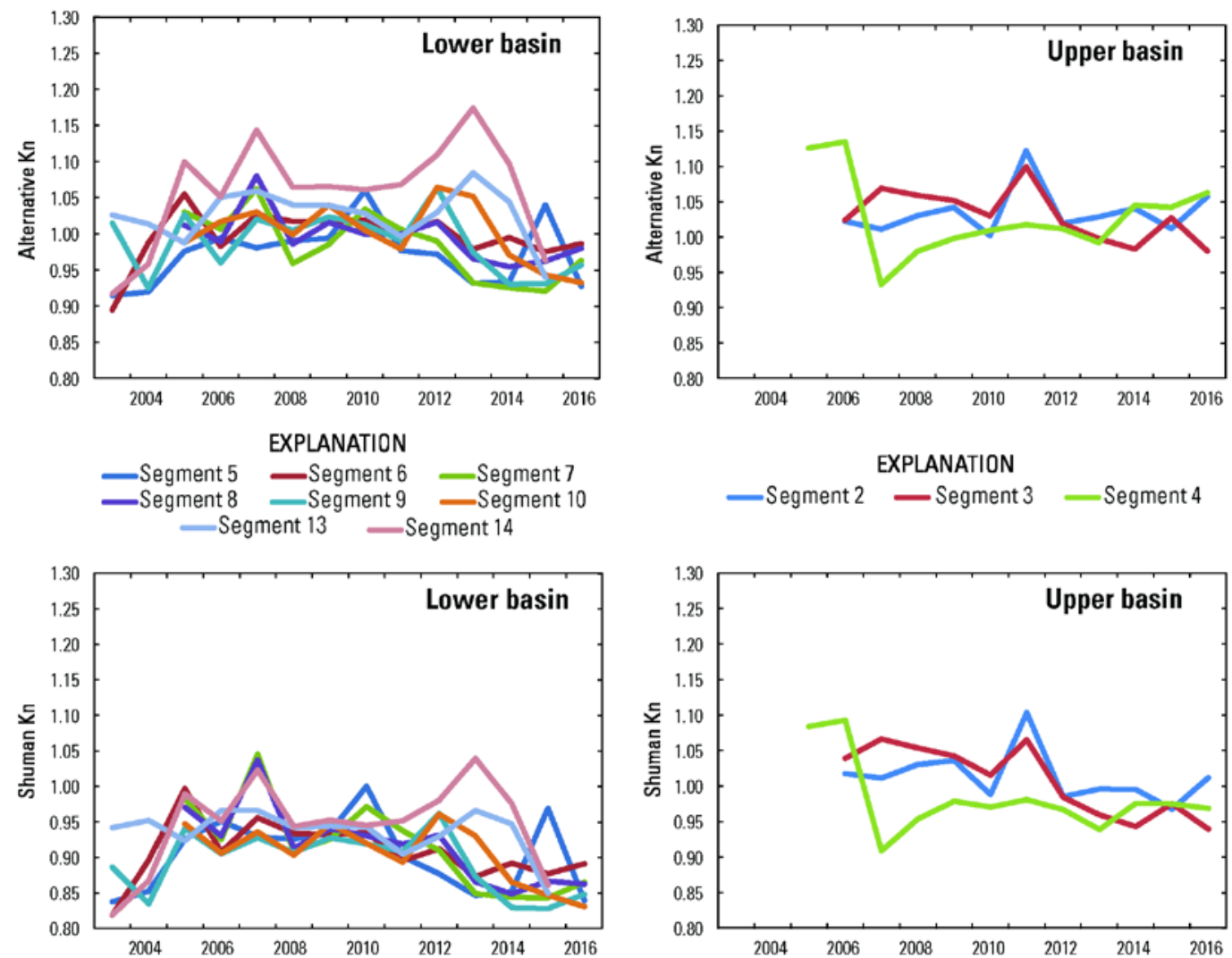

Figure 10. Shuman and Alternative Kn by selected segment by year (segments with $\mathrm{N}$ greater than or equal to 714 , all years combined). Segments 2, 3, and 4 are upper basin, whereas segments 5-14 are lower basin. Segment 9 is the reach sampled by Nebraska Game and Parks Commission. Data availability: Welker and Drobish (2016).

Table 4. Descriptive statistics of Shuman and Alternative Kn values for the full and reduced datasets of Missouri River pallid sturgeon.

[Data availability: Welker and Drobish (2016).]

\begin{tabular}{lcc}
\hline & Shuman Kn & Alternative Kn \\
\hline Mean & 0.9389 & 1.0073 \\
Standard Error & 0.0011 & 0.0011 \\
Median & 0.9299 & 1.0035 \\
Mode & 0.922 & 0.9533 \\
Standard Deviation & 0.126 & 0.1241 \\
Sample Variance & 0.0159 & 0.0154 \\
Kurtosis & 3.787 & 4.7345 \\
Skewness & 0.8474 & 0.6331 \\
Range & 1.6001 & 1.8811 \\
Minimum & 0.2914 & 0.3138 \\
Maximum & 1.8915 & 2.1949 \\
Count & 12,053 & 12,053 \\
\hline
\end{tabular}




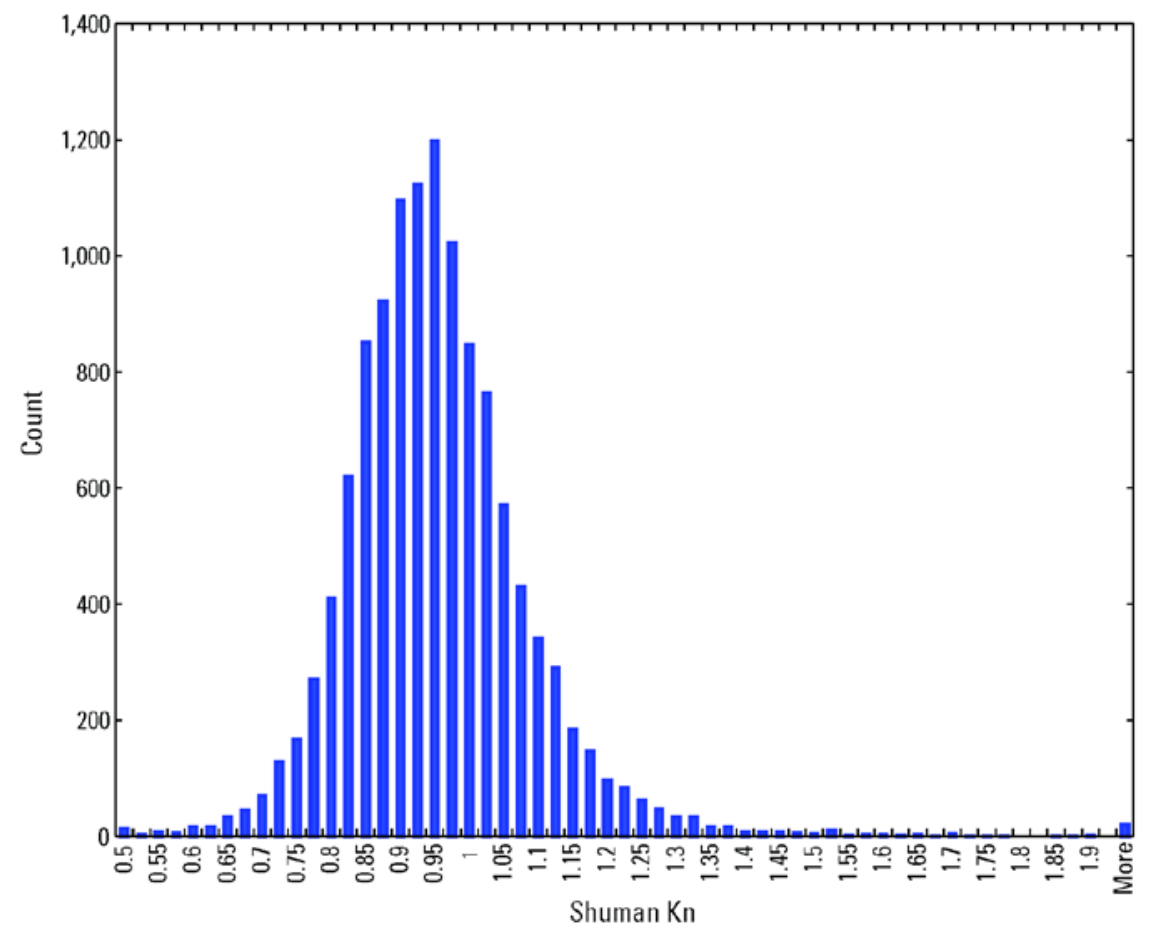

Figure 11A. Histograms of $A$, Shuman $\mathrm{Kn}$ values and $B$, Alternative $\mathrm{Kn}$ values for pallid sturgeon from the Missouri River. Data availability: Welker and Drobish (2016).

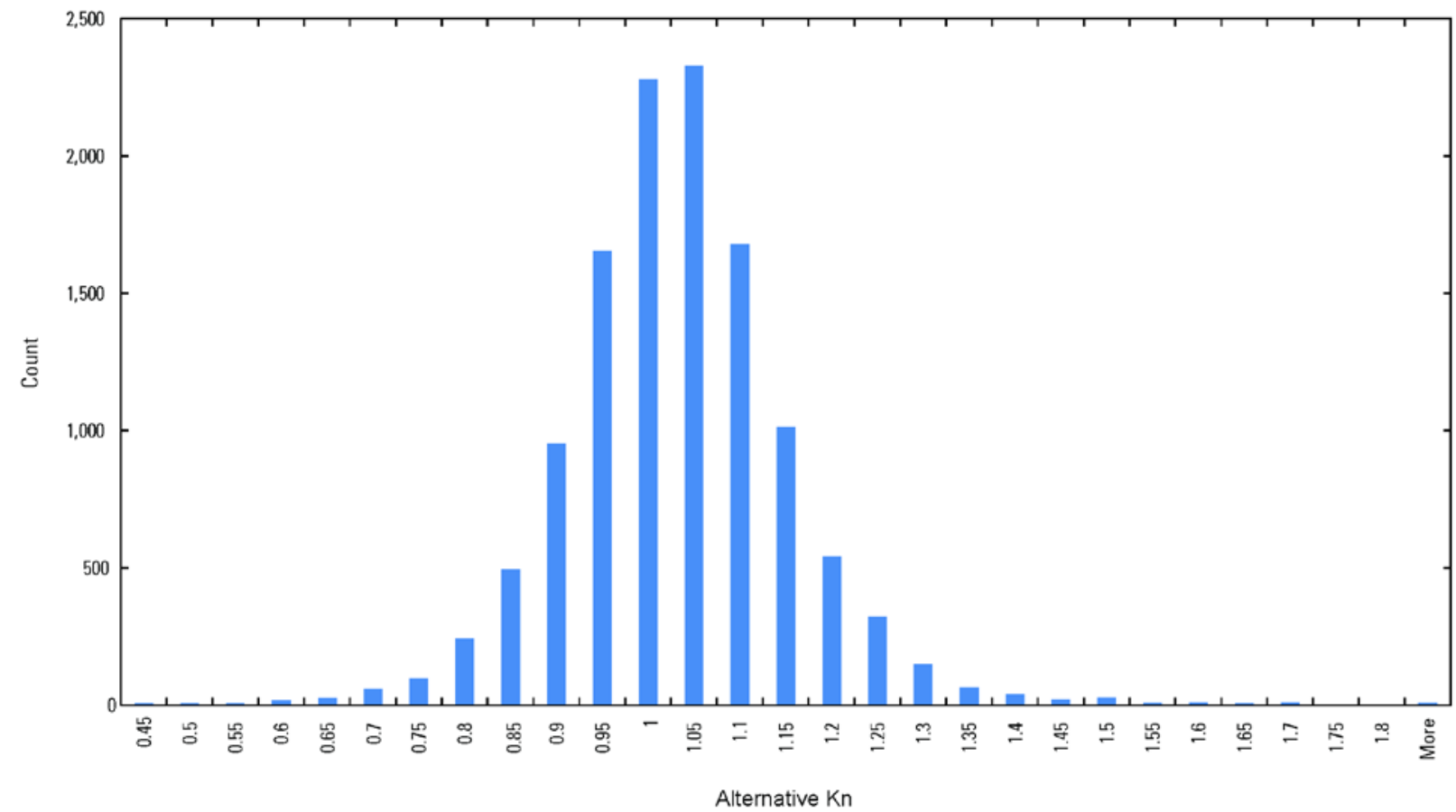

Figure 11B. Histograms of $A$, Shuman $\mathrm{Kn}$ values and $B$, Alternative $\mathrm{Kn}$ values for pallid sturgeon from the Missouri River. Data availability: Welker and Drobish (2016). 
Table 5A. Count of observations of pallid sturgeon in each condition class by basin and year, using $A$, Shuman $\mathrm{Kn}$ and $B$, Alternative Kn.

[Data availability: Welker and Drobish (2016).]

\begin{tabular}{|c|c|c|c|c|c|c|c|c|}
\hline \multirow{2}{*}{ Year } & \multicolumn{7}{|c|}{ Condition class } & \multirow{2}{*}{ Annual total } \\
\hline & -3 & -2 & -1 & $\mathbf{0}$ & 1 & 2 & 3 & \\
\hline \multicolumn{9}{|c|}{ Upper basin } \\
\hline 2003 & - & 1 & 19 & 30 & - & - & - & 50 \\
\hline 2004 & 1 & - & 9 & 18 & - & - & - & 28 \\
\hline 2005 & - & 1 & 7 & 40 & 11 & 6 & 2 & 67 \\
\hline 2006 & - & 1 & 2 & 88 & 22 & 10 & 3 & 126 \\
\hline 2007 & - & 5 & 23 & 152 & 45 & 13 & 3 & 241 \\
\hline 2008 & 2 & 2 & 15 & 219 & 48 & 23 & 7 & 316 \\
\hline 2009 & 1 & 1 & 33 & 365 & 77 & 36 & 9 & 522 \\
\hline 2010 & 5 & 15 & 61 & 760 & 178 & 36 & 12 & 1,067 \\
\hline 2011 & 1 & 9 & 19 & 410 & 120 & 43 & 18 & 620 \\
\hline 2012 & 2 & 4 & 41 & 634 & 101 & 18 & 7 & 807 \\
\hline 2013 & 3 & 7 & 64 & 668 & 71 & 13 & 4 & 830 \\
\hline 2014 & 1 & 4 & 46 & 633 & 88 & 11 & 6 & 789 \\
\hline 2015 & - & 4 & 38 & 538 & 88 & 12 & 4 & 684 \\
\hline 2016 & 1 & - & 9 & 89 & 10 & 2 & - & 111 \\
\hline Class total & 17 & 54 & 386 & 4,644 & 859 & 223 & 75 & 6,258 \\
\hline \multicolumn{9}{|c|}{ Lower basin } \\
\hline 2003 & - & - & 2 & 8 & - & - & - & 10 \\
\hline 2004 & - & 2 & 2 & 19 & 1 & - & - & 24 \\
\hline 2005 & - & 1 & 3 & 48 & 5 & - & 1 & 58 \\
\hline 2006 & 1 & 1 & 5 & 69 & 4 & - & 2 & 82 \\
\hline 2007 & - & 4 & 8 & 141 & 36 & 11 & 10 & 210 \\
\hline 2008 & 3 & 5 & 51 & 455 & 24 & 4 & 4 & 546 \\
\hline 2009 & 2 & 6 & 42 & 584 & 50 & 4 & 2 & 690 \\
\hline 2010 & 1 & 4 & 40 & 550 & 47 & 10 & 4 & 656 \\
\hline 2011 & - & 7 & 55 & 522 & 27 & 5 & 2 & 618 \\
\hline 2012 & 1 & 3 & 72 & 545 & 51 & 13 & 5 & 690 \\
\hline 2013 & - & 11 & 119 & 468 & 23 & 3 & 2 & 626 \\
\hline 2014 & 1 & 24 & 211 & 388 & 11 & 1 & 4 & 640 \\
\hline 2015 & - & 24 & 227 & 362 & 16 & 3 & 4 & 636 \\
\hline 2016 & - & 2 & 99 & 204 & 2 & 1 & - & 308 \\
\hline Class total & 9 & 94 & 936 & 4,363 & 297 & 55 & 40 & 5,794 \\
\hline Grand total & 26 & 148 & 1,322 & 9,007 & 1,156 & 278 & 115 & 12,052 \\
\hline
\end{tabular}


Table 5B. Count of observations of pallid sturgeon in each condition class by basin and year, using $A$, Shuman $\mathrm{Kn}$ and $B$, Alternative Kn.

\begin{tabular}{|c|c|c|c|c|c|c|c|c|}
\hline \multicolumn{9}{|c|}{ [Data availability: Welker and Drobish (2016).] } \\
\hline \multirow{2}{*}{ Year } & \multicolumn{7}{|c|}{ Condition class } & \multirow{2}{*}{ Annual total } \\
\hline & -3 & -2 & -1 & $\mathbf{0}$ & 1 & 2 & 3 & \\
\hline \multicolumn{9}{|c|}{ Upper basin } \\
\hline 2003 & - & 1 & 14 & 35 & - & - & - & 50 \\
\hline 2004 & 1 & - & 7 & 20 & - & - & - & 28 \\
\hline 2005 & - & 1 & 7 & 45 & 9 & 3 & 2 & 67 \\
\hline 2006 & - & 2 & 8 & 92 & 19 & 3 & 2 & 126 \\
\hline 2007 & 2 & 10 & 28 & 163 & 29 & 7 & 3 & 242 \\
\hline 2008 & 2 & 7 & 25 & 227 & 43 & 10 & 2 & 316 \\
\hline 2009 & 2 & 7 & 50 & 369 & 75 & 17 & 2 & 522 \\
\hline 2010 & 13 & 21 & 94 & 785 & 120 & 25 & 9 & 1,067 \\
\hline 2011 & 3 & 8 & 33 & 431 & 107 & 28 & 10 & 620 \\
\hline 2012 & 2 & 7 & 53 & 659 & 70 & 9 & 7 & 807 \\
\hline 2013 & 5 & 9 & 78 & 679 & 47 & 7 & 5 & 830 \\
\hline 2014 & 1 & 7 & 57 & 615 & 94 & 8 & 7 & 789 \\
\hline 2015 & - & 6 & 43 & 531 & 87 & 13 & 4 & 684 \\
\hline 2016 & 1 & - & 8 & 88 & 13 & 1 & - & 111 \\
\hline Class total & 32 & 86 & 505 & 4,739 & 713 & 131 & 53 & 6,259 \\
\hline \multicolumn{9}{|c|}{ Lower basin } \\
\hline 2003 & - & - & 1 & 9 & - & - & - & 10 \\
\hline 2004 & 1 & 2 & 2 & 17 & 2 & - & - & 24 \\
\hline 2005 & - & 1 & 6 & 45 & 5 & - & 1 & 58 \\
\hline 2006 & 2 & 1 & 7 & 62 & 8 & - & 2 & 82 \\
\hline 2007 & 2 & 2 & 10 & 139 & 40 & 10 & 7 & 210 \\
\hline 2008 & 4 & 6 & 39 & 446 & 41 & 7 & 3 & 546 \\
\hline 2009 & 4 & 4 & 37 & 568 & 69 & 6 & 2 & 690 \\
\hline 2010 & 3 & 7 & 39 & 535 & 57 & 11 & 4 & 656 \\
\hline 2011 & 3 & 14 & 71 & 460 & 61 & 6 & 3 & 618 \\
\hline 2012 & 1 & 12 & 73 & 481 & 85 & 23 & 15 & 690 \\
\hline 2013 & - & 14 & 104 & 441 & 52 & 11 & 4 & 626 \\
\hline 2014 & 1 & 24 & 154 & 428 & 26 & 3 & 4 & 640 \\
\hline 2015 & - & 22 & 159 & 425 & 24 & 3 & 3 & 636 \\
\hline 2016 & - & 4 & 49 & 240 & 14 & - & 1 & 308 \\
\hline Class total & 21 & 113 & 751 & 4,296 & 484 & 80 & 49 & 5,794 \\
\hline Grand total & 53 & 199 & 1,256 & 9,035 & 1,197 & 211 & 102 & 12,053 \\
\hline
\end{tabular}


Table 6A. Percentage of observations of pallid sturgeon in each condition class by basin and year, using $A$, Shuman $\mathrm{Kn}$ and $B$, Alternative $\mathrm{Kn}$.

[Data availability: Welker and Drobish (2016).]

\begin{tabular}{|c|c|c|c|c|c|c|c|}
\hline \multirow{2}{*}{ Year } & \multicolumn{7}{|c|}{ Condition class } \\
\hline & -3 & -2 & -1 & $\mathbf{0}$ & 1 & 2 & 3 \\
\hline \multicolumn{8}{|c|}{ Upper basin } \\
\hline 2003 & 0.00 & 2.00 & 38.00 & 60.00 & 0.00 & 0.00 & 0.00 \\
\hline 2004 & 3.57 & 0.00 & 32.14 & 64.29 & 0.00 & 0.00 & 0.00 \\
\hline 2005 & 0.00 & 1.49 & 10.45 & 59.70 & 16.42 & 8.96 & 2.99 \\
\hline 2006 & 0.00 & 0.79 & 1.59 & 69.84 & 17.46 & 7.94 & 2.38 \\
\hline 2007 & 0.00 & 2.07 & 9.54 & 63.07 & 18.67 & 5.39 & 1.24 \\
\hline 2008 & 0.63 & 0.63 & 4.75 & 69.30 & 15.19 & 7.28 & 2.22 \\
\hline 2009 & 0.19 & 0.19 & 6.32 & 69.92 & 14.75 & 6.90 & 1.72 \\
\hline 2010 & 0.47 & 1.41 & 5.72 & 71.23 & 16.68 & 3.37 & 1.12 \\
\hline 2011 & 0.16 & 1.45 & 3.06 & 66.13 & 19.35 & 6.94 & 2.90 \\
\hline 2012 & 0.25 & 0.50 & 5.08 & 78.56 & 12.52 & 2.23 & 0.87 \\
\hline 2013 & 0.36 & 0.84 & 7.71 & 80.48 & 8.55 & 1.57 & 0.48 \\
\hline 2014 & 0.13 & 0.51 & 5.83 & 80.23 & 11.15 & 1.39 & 0.76 \\
\hline 2015 & 0.00 & 0.58 & 5.56 & 78.65 & 12.87 & 1.75 & 0.58 \\
\hline 2016 & 0.90 & 0.00 & 8.11 & 80.18 & 9.01 & 1.80 & 0.00 \\
\hline Class total & 0.27 & 0.86 & 6.17 & 74.21 & 13.73 & 3.56 & 1.20 \\
\hline \multicolumn{8}{|c|}{ Lower basin } \\
\hline 2003 & 0.00 & 0.00 & 20.00 & 80.00 & 0.00 & 0.00 & 0.00 \\
\hline 2004 & 0.00 & 8.33 & 8.33 & 79.17 & 4.17 & 0.00 & 0.00 \\
\hline 2005 & 0.00 & 1.72 & 5.17 & 82.76 & 8.62 & 0.00 & 1.72 \\
\hline 2006 & 1.22 & 1.22 & 6.10 & 84.15 & 4.88 & 0.00 & 2.44 \\
\hline 2007 & 0.00 & 1.90 & 3.81 & 67.14 & 17.14 & 5.24 & 4.76 \\
\hline 2008 & 0.55 & 0.92 & 9.34 & 83.33 & 4.40 & 0.73 & 0.73 \\
\hline 2009 & 0.29 & 0.87 & 6.09 & 84.64 & 7.25 & 0.58 & 0.29 \\
\hline 2010 & 0.15 & 0.61 & 6.10 & 83.84 & 7.16 & 1.52 & 0.61 \\
\hline 2011 & 0.00 & 1.13 & 8.90 & 84.47 & 4.37 & 0.81 & 0.32 \\
\hline 2012 & 0.14 & 0.43 & 10.43 & 78.99 & 7.39 & 1.88 & 0.72 \\
\hline 2013 & 0.00 & 1.76 & 19.01 & 74.76 & 3.67 & 0.48 & 0.32 \\
\hline 2014 & 0.16 & 3.75 & 32.97 & 60.63 & 1.72 & 0.16 & 0.63 \\
\hline 2015 & 0.00 & 3.77 & 35.69 & 56.92 & 2.52 & 0.47 & 0.63 \\
\hline 2016 & 0.00 & 0.65 & 32.14 & 66.23 & 0.65 & 0.32 & 0.00 \\
\hline Class total & 0.16 & 1.62 & 16.15 & 75.30 & 5.13 & 0.95 & 0.69 \\
\hline Grand total & 0.22 & 1.23 & 10.97 & 74.73 & 9.59 & 2.31 & 0.95 \\
\hline
\end{tabular}


Table 6B. Percentage of observations of pallid sturgeon in each condition class by basin and year, using $A$, Shuman $\mathrm{Kn}$ and $B$, Alternative Kn.

\begin{tabular}{|c|c|c|c|c|c|c|c|}
\hline \multirow{2}{*}{ Year } & \multicolumn{7}{|c|}{ Condition class } \\
\hline & -3 & -2 & -1 & $\mathbf{0}$ & 1 & 2 & 3 \\
\hline \multicolumn{8}{|c|}{ Upper basin } \\
\hline 2003 & 0.00 & 2.00 & 28.00 & 70.00 & 0.00 & 0.00 & 0.00 \\
\hline 2004 & 3.60 & 0.00 & 25.00 & 71.40 & 0.00 & 0.00 & 0.00 \\
\hline 2005 & 0.00 & 1.50 & 10.40 & 67.20 & 13.40 & 4.50 & 3.00 \\
\hline 2006 & 0.00 & 1.60 & 6.30 & 73.00 & 15.10 & 2.40 & 1.60 \\
\hline 2007 & 0.80 & 4.10 & 11.60 & 67.40 & 12.00 & 2.90 & 1.20 \\
\hline 2008 & 0.60 & 2.20 & 7.90 & 71.80 & 13.60 & 3.20 & 0.60 \\
\hline 2009 & 0.40 & 1.30 & 9.60 & 70.70 & 14.40 & 3.30 & 0.40 \\
\hline 2010 & 1.20 & 2.00 & 8.80 & 73.60 & 11.20 & 2.30 & 0.80 \\
\hline 2011 & 0.50 & 1.30 & 5.30 & 69.50 & 17.30 & 4.50 & 1.60 \\
\hline 2012 & 0.20 & 0.90 & 6.60 & 81.70 & 8.70 & 1.10 & 0.90 \\
\hline 2013 & 0.60 & 1.10 & 9.40 & 81.80 & 5.70 & 0.80 & 0.60 \\
\hline 2014 & 0.10 & 0.90 & 7.20 & 77.90 & 11.90 & 1.00 & 0.90 \\
\hline 2015 & 0.00 & 0.90 & 6.30 & 77.60 & 12.70 & 1.90 & 0.60 \\
\hline 2016 & 0.90 & 0.00 & 7.20 & 79.30 & 11.70 & 0.90 & 0.00 \\
\hline Class total & 0.51 & 1.37 & 8.07 & 75.71 & 11.39 & 2.09 & 0.85 \\
\hline \multicolumn{8}{|c|}{ Lower basin } \\
\hline 2003 & 0.00 & 0.00 & 10.00 & 90.00 & 0.00 & 0.00 & 0.00 \\
\hline 2004 & 4.20 & 8.30 & 8.30 & 70.80 & 8.30 & 0.00 & 0.00 \\
\hline 2005 & 0.00 & 1.70 & 10.30 & 77.60 & 8.60 & 0.00 & 1.70 \\
\hline 2006 & 2.40 & 1.20 & 8.50 & 75.60 & 9.80 & 0.00 & 2.40 \\
\hline 2007 & 1.00 & 1.00 & 4.80 & 66.20 & 19.00 & 4.80 & 3.30 \\
\hline 2008 & 0.70 & 1.10 & 7.10 & 81.70 & 7.50 & 1.30 & 0.50 \\
\hline 2009 & 0.60 & 0.60 & 5.40 & 82.30 & 10.00 & 0.90 & 0.30 \\
\hline 2010 & 0.50 & 1.10 & 5.90 & 81.60 & 8.70 & 1.70 & 0.60 \\
\hline 2011 & 0.50 & 2.30 & 11.50 & 74.40 & 9.90 & 1.00 & 0.50 \\
\hline 2012 & 0.10 & 1.70 & 10.60 & 69.70 & 12.30 & 3.30 & 2.20 \\
\hline 2013 & 0.00 & 2.20 & 16.60 & 70.40 & 8.30 & 1.80 & 0.60 \\
\hline 2014 & 0.20 & 3.80 & 24.10 & 66.90 & 4.10 & 0.50 & 0.60 \\
\hline 2015 & 0.00 & 3.50 & 25.00 & 66.80 & 3.80 & 0.50 & 0.50 \\
\hline 2016 & 0.00 & 1.30 & 15.90 & 77.90 & 4.50 & 0.00 & 0.30 \\
\hline Class total & 0.36 & 1.95 & 12.96 & 74.15 & 8.35 & 1.38 & 0.85 \\
\hline Grand total & 0.44 & 1.66 & 10.52 & 74.93 & 9.87 & 1.74 & 0.85 \\
\hline
\end{tabular}


We further examined the pallid sturgeon data by segment (tables $7 A, B ; 8 A, B$ ), size class (tables $9 A, B ; 10 A, B$ ), and origin (wild vs. hatchery; tables $11 A, B ; 12 A, B ; 13 A, B$ ).

Table 7A. Count of observations of pallid sturgeon in each condition class by basin and segment, using $A$, Shuman $\mathrm{Kn}$ and $B$, Alternative $\mathrm{Kn}$.

\begin{tabular}{|c|c|c|c|c|c|c|c|c|}
\hline \multicolumn{9}{|c|}{ [Data availability: Welker and Drobish (2016).] } \\
\hline \multirow{2}{*}{ Segment } & \multicolumn{7}{|c|}{ Condition class } & \multirow{2}{*}{ Segment total } \\
\hline & -3 & -2 & -1 & $\mathbf{0}$ & 1 & 2 & 3 & \\
\hline \multicolumn{9}{|c|}{ Upper basin } \\
\hline 1 & - & - & - & 1 & - & - & - & 1 \\
\hline 2 & 1 & 3 & 24 & 504 & 130 & 40 & 8 & 710 \\
\hline 3 & 2 & 10 & 56 & 1,047 & 311 & 104 & 36 & 1,566 \\
\hline 4 & 7 & 19 & 177 & 2,092 & 356 & 64 & 23 & 2,738 \\
\hline 5 & 3 & 15 & 61 & 354 & 18 & 3 & 5 & 459 \\
\hline 6 & 4 & 4 & 59 & 614 & 38 & 10 & 1 & 730 \\
\hline 21 & - & - & - & 2 & 1 & - & - & 3 \\
\hline 22 & - & 3 & 7 & 8 & 1 & 1 & 2 & 22 \\
\hline 23 & - & - & 1 & 2 & - & - & - & 3 \\
\hline 52 & - & - & 1 & 20 & 4 & 1 & - & 26 \\
\hline Class total & 17 & 54 & 386 & 4,644 & 859 & 223 & 75 & 6,258 \\
\hline \multicolumn{9}{|c|}{ Lower basin } \\
\hline 7 & 3 & 12 & 158 & 916 & 68 & 15 & 11 & 1,183 \\
\hline 8 & 22 & 21 & 134 & 630 & 40 & 11 & 10 & 848 \\
\hline 9 & 3 & 48 & 513 & 1,817 & 93 & 17 & 9 & 2,500 \\
\hline 10 & 1 & 9 & 62 & 385 & 34 & 4 & 1 & 496 \\
\hline 11 & - & 1 & - & 16 & 1 & 1 & - & 19 \\
\hline 13 & - & 2 & 41 & 415 & 32 & - & 6 & 496 \\
\hline 14 & - & 1 & 28 & 182 & 29 & 7 & 3 & 250 \\
\hline 24 & - & - & - & 1 & - & - & - & 1 \\
\hline 28 & - & - & - & 1 & - & - & - & 1 \\
\hline Class total & 9 & 94 & 936 & 4,363 & 297 & 55 & 40 & 5,794 \\
\hline Grand total & 1261 & 148 & 1,322 & 9,0071 & 1,156 & 6278 & 115 & 12,052 \\
\hline
\end{tabular}


Table 7B. Count of observations of pallid sturgeon in each condition class by basin and segment, using $A$, Shuman $\mathrm{Kn}$ and $B$, Alternative $\mathrm{Kn}$.

[Data availability: Welker and Drobish (2016).]

\begin{tabular}{ccccccccc}
\hline \multirow{2}{*}{ Segment } & \multicolumn{7}{c}{ Condition class } & Segment total \\
\cline { 2 - 7 } & $\mathbf{- 3}$ & $\mathbf{- 2}$ & $\mathbf{- 1}$ & $\mathbf{0}$ & $\mathbf{1}$ & $\mathbf{2}$ & $\mathbf{3}$ & \\
\hline $\mathbf{7}$ & - & - & - & 1 & - & - & - & 1 \\
$\mathbf{2}$ & 1 & 5 & 36 & 546 & 97 & 20 & 5 & 710 \\
$\mathbf{3}$ & 4 & 16 & 124 & 1,123 & 233 & 47 & 19 & 1,566 \\
$\mathbf{4}$ & 16 & 43 & 232 & 2,073 & 307 & 47 & 20 & 2,738 \\
$\mathbf{5}$ & 5 & 13 & 54 & 358 & 19 & 6 & 4 & 459 \\
$\mathbf{6}$ & 4 & 6 & 50 & 606 & 52 & 11 & 2 & 731 \\
$\mathbf{2 1}$ & - & - & 1 & 2 & - & - & - & 3 \\
$\mathbf{2 2}$ & 2 & 3 & 6 & 6 & 1 & 1 & 3 & 22 \\
$\mathbf{2 3}$ & - & - & 1 & 2 & - & - & - & 3 \\
$\mathbf{5 2}$ & - & - & 1 & 22 & 3 & - & - & 26 \\
\hline Class total & 32 & 86 & 505 & 4,739 & 712 & 132 & 53 & 6,259 \\
\hline \multicolumn{7}{c}{} & & \multicolumn{7}{c}{ Lower basin } & & \\
\hline $\mathbf{7}$ & 5 & 16 & 160 & 901 & 82 & 12 & 7 & 1,183 \\
$\mathbf{8}$ & 6 & 21 & 113 & 631 & 63 & 7 & 7 & 848 \\
$\mathbf{9}$ & 7 & 55 & 375 & 1,834 & 182 & 29 & 18 & 2,500 \\
$\mathbf{1 0}$ & 1 & 14 & 45 & 378 & 44 & 11 & 3 & 496 \\
$\mathbf{1 1}$ & - & 1 & - & 16 & 1 & - & 1 & 19 \\
$\mathbf{1 3}$ & 1 & 5 & 38 & 382 & 60 & 6 & 4 & 496 \\
$\mathbf{1 4}$ & 1 & 1 & 21 & 152 & 51 & 15 & 9 & 250 \\
$\mathbf{2 4}$ & - & - & - & 1 & - & - & - & 1 \\
$\mathbf{2 8}$ & - & - & - & 1 & - & - & - & 1 \\
\hline Class total & 21 & 113 & 752 & 4,296 & 483 & 80 & 49 & 5,794 \\
\hline Grand total & 53 & 199 & 1,257 & 9,035 & 1,195 & 212 & 102 & 12,053 \\
\hline & & & & & & \\
\hline
\end{tabular}


Table 8A. Percentage of observations of pallid sturgeon in each condition class by basin and segment, using $A$, Shuman $\mathrm{Kn}$ and $B$, Alternative $\mathrm{Kn}$.

[Data availability: Welker and Drobish (2016).]

\begin{tabular}{|c|c|c|c|c|c|c|c|}
\hline \multirow{2}{*}{ Segment } & \multicolumn{7}{|c|}{ Condition class } \\
\hline & -3 & -2 & -1 & $\mathbf{0}$ & 1 & 2 & 3 \\
\hline \multicolumn{8}{|c|}{ Upper basin } \\
\hline 1 & 0.00 & 0.00 & 0.00 & 100.00 & 0.00 & 0.00 & 0.00 \\
\hline 2 & 0.14 & 0.42 & 3.38 & 70.99 & 18.31 & 5.63 & 1.13 \\
\hline 3 & 0.13 & 0.64 & 3.58 & 66.86 & 19.86 & 6.64 & 2.30 \\
\hline 4 & 0.26 & 0.69 & 6.46 & 76.41 & 13.00 & 2.34 & 0.84 \\
\hline 5 & 0.65 & 3.27 & 13.29 & 77.12 & 3.92 & 0.65 & 1.09 \\
\hline 6 & 0.55 & 0.55 & 8.08 & 84.11 & 5.21 & 1.37 & 0.14 \\
\hline 21 & 0.00 & 0.00 & 0.00 & 66.67 & 33.33 & 0.00 & 0.00 \\
\hline 22 & 0.00 & 13.64 & 31.82 & 36.36 & 4.55 & 4.55 & 9.09 \\
\hline 23 & 0.00 & 0.00 & 33.33 & 66.67 & 0.00 & 0.00 & 0.00 \\
\hline 52 & 0.00 & 0.00 & 3.85 & 76.92 & 15.38 & 3.85 & 0.00 \\
\hline Class total & 0.27 & 0.86 & 6.17 & 74.21 & 13.73 & 3.56 & 1.20 \\
\hline \multicolumn{8}{|c|}{ Lower basin } \\
\hline 7 & 0.25 & 1.01 & 13.36 & 77.43 & 5.75 & 1.27 & 0.93 \\
\hline 8 & 0.24 & 2.48 & 15.80 & 74.29 & 4.72 & 1.30 & 1.18 \\
\hline 9 & 0.12 & 1.92 & 20.52 & 72.68 & 3.72 & 0.68 & 0.36 \\
\hline 10 & 0.20 & 1.81 & 12.50 & 77.62 & 6.85 & 0.81 & 0.20 \\
\hline 11 & 0.00 & 5.26 & 0.00 & 84.21 & 5.26 & 5.26 & 0.00 \\
\hline 13 & 0.00 & 0.40 & 8.27 & 83.67 & 6.45 & 0.00 & 1.21 \\
\hline 14 & 0.00 & 0.40 & 11.20 & 72.80 & 11.60 & 2.80 & 1.20 \\
\hline 24 & 0.00 & 0.00 & 0.00 & 100.00 & 0.00 & 0.00 & 0.00 \\
\hline 28 & 0.00 & 0.00 & 0.00 & 100.00 & 0.00 & 0.00 & 0.00 \\
\hline Class total & 0.16 & 1.62 & 16.15 & 75.30 & 5.13 & 0.95 & 0.69 \\
\hline $\begin{array}{c}\text { Grand } \\
\text { total }\end{array}$ & 0.22 & 1.23 & 10.97 & 73 & 9.59 & 2.31 & 0.95 \\
\hline
\end{tabular}


Table 8B. Percentage of observations of pallid sturgeon in each condition class by basin and segment, using $A$, Shuman $\mathrm{Kn}$ and $B$, Alternative $\mathrm{Kn}$.

[Data availability: Welker and Drobish (2016).]

\begin{tabular}{|c|c|c|c|c|c|c|c|}
\hline \multirow{2}{*}{ Segment } & \multicolumn{7}{|c|}{ Condition class } \\
\hline & -3 & -2 & -1 & $\mathbf{0}$ & 1 & 2 & 3 \\
\hline \multicolumn{8}{|c|}{ Upper basin } \\
\hline 1 & 0.00 & 0.00 & 0.00 & 100.00 & 0.00 & 0.00 & 0.00 \\
\hline 2 & 0.10 & 0.70 & 5.10 & 76.90 & 13.70 & 2.80 & 0.70 \\
\hline 3 & 0.30 & 1.00 & 7.90 & 71.70 & 14.90 & 3.00 & 1.20 \\
\hline 4 & 0.60 & 1.60 & 8.50 & 75.70 & 11.20 & 1.70 & 0.70 \\
\hline 5 & 1.10 & 2.80 & 11.80 & 78.00 & 4.10 & 1.30 & 0.90 \\
\hline 6 & 0.50 & 0.80 & 6.80 & 82.90 & 7.10 & 1.50 & 0.30 \\
\hline 21 & 0.00 & 0.00 & 33.30 & 66.70 & 0.00 & 0.00 & 0.00 \\
\hline 22 & 9.10 & 13.60 & 27.30 & 27.30 & 4.50 & 4.50 & 13.60 \\
\hline 23 & 0.00 & 0.00 & 33.30 & 66.70 & 0.00 & 0.00 & 0.00 \\
\hline 52 & 0.00 & 0.00 & 3.80 & 84.60 & 11.50 & 0.00 & 0.00 \\
\hline Class total & 0.51 & 1.37 & 8.07 & 75.71 & 11.38 & 2.11 & 0.85 \\
\hline \multicolumn{8}{|c|}{ Lower basin } \\
\hline 7 & 0.40 & 1.40 & 13.50 & 76.20 & 6.90 & 1.00 & 0.60 \\
\hline 8 & 0.70 & 2.50 & 13.30 & 74.40 & 7.40 & 0.80 & 0.80 \\
\hline 9 & 0.30 & 2.20 & 15.00 & 73.40 & 7.30 & 1.20 & 0.70 \\
\hline 10 & 0.20 & 2.80 & 9.10 & 76.20 & 8.90 & 2.20 & 0.60 \\
\hline 11 & 0.00 & 5.30 & 0.00 & 84.20 & 5.30 & 0.00 & 5.30 \\
\hline 13 & 0.20 & 1.00 & 7.70 & 77.00 & 12.10 & 1.20 & 0.80 \\
\hline 14 & 0.40 & 0.40 & 8.40 & 60.80 & 20.40 & 6.00 & 3.60 \\
\hline 24 & 0.00 & 0.00 & 0.00 & 100.00 & 0.00 & 0.00 & 0.00 \\
\hline 28 & 0.00 & 0.00 & 0.00 & 100.00 & 0.00 & 0.00 & 0.00 \\
\hline Class total & 0.36 & 1.95 & 12.98 & 74.15 & 8.34 & 1.38 & 0.85 \\
\hline $\begin{array}{c}\text { Grand } \\
\text { total }\end{array}$ & 0.44 & 1.66 & 10.52 & 74.93 & 9.86 & 1.74 & 0.85 \\
\hline
\end{tabular}


Table 9A. Count of observations of pallid sturgeon in each condition class by basin and size class, using $A$, Shuman $\mathrm{Kn}$ and $B$, Alternative $\mathrm{Kn}$.

[Data availability: Welker and Drobish (2016).

\begin{tabular}{|c|c|c|c|c|c|c|c|c|}
\hline \multirow{2}{*}{ Size } & \multicolumn{7}{|c|}{ Condition class } & \multirow{2}{*}{ Size total } \\
\hline & -3 & -2 & -1 & $\mathbf{0}$ & 1 & 2 & 3 & \\
\hline \multicolumn{9}{|c|}{ Upper basin } \\
\hline 200 & - & 5 & 21 & 197 & 171 & 99 & 43 & 536 \\
\hline 300 & 5 & 19 & 111 & 1,603 & 453 & 95 & 21 & 2,307 \\
\hline 400 & 6 & 13 & 119 & 1,526 & 179 & 20 & 7 & 1,870 \\
\hline 500 & 3 & 8 & 43 & 560 & 34 & 5 & - & 653 \\
\hline 600 & 2 & 5 & 60 & 342 & 11 & - & 1 & 421 \\
\hline 700 & - & 4 & 12 & 211 & 3 & - & - & 230 \\
\hline 800 & 1 & - & 7 & 136 & 3 & - & - & 147 \\
\hline 900 & - & - & 5 & 35 & 4 & 1 & - & 45 \\
\hline 1,000 & - & - & 7 & 22 & - & 1 & - & 30 \\
\hline 1,100 & - & - & 1 & 12 & 1 & 2 & 3 & 19 \\
\hline Class total & 17 & 54 & 386 & 4,644 & 859 & 223 & 75 & 6,258 \\
\hline \multicolumn{9}{|c|}{ Lower basin } \\
\hline 200 & - & 2 & 4 & 31 & 20 & 11 & 19 & 87 \\
\hline 300 & 1 & 17 & 54 & 299 & 52 & 12 & 5 & 440 \\
\hline 400 & 3 & 22 & 146 & 775 & 80 & 7 & 4 & 1,037 \\
\hline 500 & 2 & 18 & 240 & 1,070 & 47 & 2 & 6 & 1,385 \\
\hline 600 & 2 & 16 & 155 & 755 & 20 & 3 & 3 & 954 \\
\hline 700 & - & 5 & 97 & 512 & 22 & 6 & 3 & 645 \\
\hline 800 & - & 5 & 102 & 473 & 33 & 10 & - & 623 \\
\hline 900 & 1 & 5 & 103 & 329 & 16 & 2 & - & 456 \\
\hline 1,000 & - & 3 & 28 & 117 & 7 & 1 & - & 156 \\
\hline 1,100 & - & 1 & 7 & 2 & - & 1 & - & 11 \\
\hline Class total & 9 & 94 & 936 & 4,363 & 297 & 55 & 40 & 5,794 \\
\hline Grand total & 26 & 148 & 1,322 & 9,007 & 1,156 & 278 & 115 & 12,052 \\
\hline
\end{tabular}


Table 9B. Count of observations of pallid sturgeon in each condition class by basin and size class, using $A$, Shuman $\mathrm{Kn}$ and $B$, Alternative $\mathrm{Kn}$.

[Data availability: Welker and Drobish (2016).]

\begin{tabular}{|c|c|c|c|c|c|c|c|c|}
\hline \multirow{2}{*}{ Size } & \multicolumn{7}{|c|}{ Condition class } & \multirow{2}{*}{ Size total } \\
\hline & -3 & -2 & -1 & $\mathbf{0}$ & 1 & 2 & 3 & \\
\hline \multicolumn{9}{|c|}{ Upper basin } \\
\hline 200 & 5 & 12 & 37 & 288 & 134 & 44 & 16 & 536 \\
\hline 300 & 11 & 38 & 191 & 1,713 & 292 & 44 & 18 & 2,307 \\
\hline 400 & 9 & 20 & 181 & 1,475 & 156 & 22 & 7 & 1,870 \\
\hline 500 & 4 & 7 & 45 & 538 & 46 & 10 & 4 & 654 \\
\hline 600 & 2 & 5 & 42 & 342 & 27 & 2 & 1 & 421 \\
\hline 700 & - & 4 & 4 & 197 & 23 & 2 & - & 230 \\
\hline 800 & 1 & - & 2 & 122 & 21 & 1 & - & 147 \\
\hline 900 & - & - & 2 & 32 & 6 & 4 & 1 & 45 \\
\hline 1,000 & - & - & 1 & 23 & 4 & 1 & 1 & 30 \\
\hline 1,100 & - & - & - & 9 & 3 & 2 & 5 & 19 \\
\hline Class total & 32 & 86 & 505 & 4,739 & 712 & 132 & 53 & 6,259 \\
\hline \multicolumn{9}{|c|}{ Lower basin } \\
\hline 200 & 2 & 2 & 9 & 38 & 19 & 7 & 10 & 87 \\
\hline 300 & 8 & 28 & 98 & 259 & 35 & 8 & 4 & 440 \\
\hline 400 & 5 & 36 & 186 & 720 & 79 & 7 & 4 & 1,037 \\
\hline 500 & 2 & 28 & 217 & 1,062 & 66 & 4 & 6 & 1,385 \\
\hline 600 & 3 & 12 & 121 & 762 & 47 & 5 & 4 & 954 \\
\hline 700 & - & 1 & 50 & 522 & 54 & 11 & 7 & 645 \\
\hline 800 & - & 4 & 34 & 462 & 93 & 20 & 10 & 623 \\
\hline 900 & 1 & 1 & 24 & 356 & 62 & 10 & 2 & 456 \\
\hline 1,000 & - & 1 & 9 & 109 & 28 & 8 & 1 & 156 \\
\hline 1,100 & - & - & 4 & 6 & - & - & 1 & 11 \\
\hline Class total & 21 & 113 & 752 & 4,296 & 483 & 80 & 49 & 5,794 \\
\hline Grand total & 53 & 199 & 1,257 & 9,035 & 1,195 & 212 & 102 & 12,053 \\
\hline
\end{tabular}


Table 10A. Percentage of observations of pallid sturgeon in each condition class by location and size class, using Shuman's Kn.

\begin{tabular}{|c|c|c|c|c|c|c|c|}
\hline \multirow{2}{*}{ Size } & \multicolumn{7}{|c|}{ Condition Class } \\
\hline & -3 & -2 & -1 & $\mathbf{0}$ & 1 & 2 & 3 \\
\hline \multicolumn{8}{|c|}{ Upper Basin } \\
\hline 200 & 0.00 & 0.01 & 0.04 & 0.37 & 0.32 & 0.18 & 0.08 \\
\hline 300 & 0.00 & 0.01 & 0.05 & 0.69 & 0.20 & 0.04 & 0.01 \\
\hline 400 & 0.00 & 0.01 & 0.06 & 0.82 & 0.10 & 0.01 & 0.00 \\
\hline 500 & 0.00 & 0.01 & 0.07 & 0.86 & 0.05 & 0.01 & 0.00 \\
\hline 600 & 0.00 & 0.01 & 0.14 & 0.81 & 0.03 & 0.00 & 0.00 \\
\hline 700 & 0.00 & 0.02 & 0.05 & 0.92 & 0.01 & 0.00 & 0.00 \\
\hline 800 & 0.01 & 0.00 & 0.05 & 0.93 & 0.02 & 0.00 & 0.00 \\
\hline 900 & 0.00 & 0.00 & 0.11 & 0.78 & 0.09 & 0.02 & 0.00 \\
\hline 1000 & 0.00 & 0.00 & 0.23 & 0.73 & 0.00 & 0.03 & 0.00 \\
\hline 1100 & 0.00 & 0.00 & 0.05 & 0.63 & 0.05 & 0.11 & 0.16 \\
\hline Total & 0.00 & 0.01 & 0.06 & 0.74 & 0.14 & 0.04 & 0.01 \\
\hline \multicolumn{8}{|c|}{ Lower Basin } \\
\hline 200 & 0.00 & 0.02 & 0.05 & 0.36 & 0.23 & 0.13 & 0.22 \\
\hline 300 & 0.00 & 0.04 & 0.12 & 0.68 & 0.12 & 0.03 & 0.01 \\
\hline 400 & 0.00 & 0.02 & 0.14 & 0.75 & 0.08 & 0.01 & 0.00 \\
\hline 500 & 0.00 & 0.01 & 0.17 & 0.77 & 0.03 & 0.00 & 0.00 \\
\hline 600 & 0.00 & 0.02 & 0.16 & 0.79 & 0.02 & 0.00 & 0.00 \\
\hline 700 & 0.00 & 0.01 & 0.15 & 0.79 & 0.03 & 0.01 & 0.00 \\
\hline 800 & 0.00 & 0.01 & 0.16 & 0.76 & 0.05 & 0.02 & 0.00 \\
\hline 900 & 0.00 & 0.01 & 0.23 & 0.72 & 0.04 & 0.00 & 0.00 \\
\hline 1000 & 0.00 & 0.02 & 0.18 & 0.75 & 0.04 & 0.01 & 0.00 \\
\hline 1100 & 0.00 & 0.09 & 0.64 & 0.18 & 0.00 & 0.09 & 0.00 \\
\hline Total & 0.00 & 0.02 & 0.16 & 0.75 & 0.05 & 0.01 & 0.01 \\
\hline Grand Total & 0.00 & 0.01 & 0.11 & 0.75 & 0.10 & 0.02 & 0.01 \\
\hline
\end{tabular}


Table 10B. Percentage of observations of pallid sturgeon in each condition class by location and size class, using Alternative Kn.

\begin{tabular}{|c|c|c|c|c|c|c|c|}
\hline \multirow{2}{*}{ Size } & \multicolumn{7}{|c|}{ Condition Class } \\
\hline & -3 & -2 & -1 & $\mathbf{0}$ & 1 & 2 & 3 \\
\hline \multicolumn{8}{|c|}{ Upper Basin } \\
\hline 200 & 0.01 & 0.02 & 0.07 & 0.54 & 0.25 & 0.08 & 0.03 \\
\hline 300 & 0.01 & 0.02 & 0.08 & 0.74 & 0.13 & 0.02 & 0.01 \\
\hline 400 & 0.01 & 0.01 & 0.10 & 0.79 & 0.08 & 0.01 & 0.00 \\
\hline 500 & 0.01 & 0.01 & 0.07 & 0.82 & 0.07 & 0.02 & 0.01 \\
\hline 600 & 0.01 & 0.01 & 0.10 & 0.81 & 0.06 & 0.01 & 0.00 \\
\hline 700 & 0.00 & 0.02 & 0.02 & 0.86 & 0.10 & 0.01 & 0.00 \\
\hline 800 & 0.01 & 0.00 & 0.01 & 0.83 & 0.14 & 0.01 & 0.00 \\
\hline 900 & 0.00 & 0.00 & 0.04 & 0.71 & 0.13 & 0.09 & 0.02 \\
\hline 1,000 & 0.00 & 0.00 & 0.03 & 0.77 & 0.13 & 0.03 & 0.03 \\
\hline 1,100 & 0.00 & 0.00 & 0.00 & 0.47 & 0.16 & 0.11 & 0.26 \\
\hline Class Total & 0.01 & 0.01 & 0.08 & 0.76 & 0.11 & 0.02 & 0.01 \\
\hline \multicolumn{8}{|c|}{ Lower Basin } \\
\hline 200 & 0.02 & 0.02 & 0.10 & 0.44 & 0.22 & 0.08 & 0.12 \\
\hline 300 & 0.02 & 0.06 & 0.22 & 0.59 & 0.08 & 0.02 & 0.01 \\
\hline 400 & 0.01 & 0.04 & 0.18 & 0.69 & 0.08 & 0.01 & 0.00 \\
\hline 500 & 0.00 & 0.02 & 0.16 & 0.77 & 0.05 & 0.00 & 0.00 \\
\hline 600 & 0.00 & 0.01 & 0.13 & 0.80 & 0.05 & 0.01 & 0.00 \\
\hline 700 & 0.00 & 0.00 & 0.08 & 0.81 & 0.08 & 0.02 & 0.01 \\
\hline 800 & 0.00 & 0.01 & 0.06 & 0.74 & 0.15 & 0.03 & 0.02 \\
\hline 900 & 0.00 & 0.00 & 0.05 & 0.78 & 0.14 & 0.02 & 0.00 \\
\hline 1,000 & 0.00 & 0.01 & 0.06 & 0.70 & 0.18 & 0.05 & 0.01 \\
\hline 1,100 & 0.00 & 0.00 & 0.36 & 0.55 & 0.00 & 0.00 & 0.09 \\
\hline Class Total & 0.00 & 0.02 & 0.13 & 0.74 & 0.08 & 0.01 & 0.01 \\
\hline Grand Total & 0.00 & 0.02 & 0.11 & 0.75 & 0.10 & 0.02 & 0.01 \\
\hline
\end{tabular}


Table 11A. Count of observations of pallid sturgeon in each condition class by year and origin (hatchery or wild), using $A$, Shuman $\mathrm{Kn}$ and $B$, Alternative $\mathrm{Kn}$.

[Data availability: Welker and Drobish (2016).]

\begin{tabular}{|c|c|c|c|c|c|c|c|c|}
\hline \multirow{2}{*}{ Year } & \multicolumn{7}{|c|}{ Condition class } & \multirow{2}{*}{$\begin{array}{c}\text { Annual } \\
\text { total }\end{array}$} \\
\hline & -3 & -2 & -1 & $\mathbf{0}$ & 1 & 2 & 3 & \\
\hline \multicolumn{9}{|c|}{ Hatchery } \\
\hline 2003 & - & - & 15 & 30 & - & - & - & 45 \\
\hline 2004 & 1 & 1 & 7 & 26 & - & - & - & 35 \\
\hline 2005 & - & - & 7 & 68 & 15 & 2 & 2 & 94 \\
\hline 2006 & - & 3 & 6 & 118 & 24 & 5 & 2 & 158 \\
\hline 2007 & - & 6 & 23 & 266 & 67 & 16 & 10 & 388 \\
\hline 2008 & 3 & 4 & 32 & 500 & 56 & 24 & 3 & 622 \\
\hline 2009 & 2 & 5 & 38 & 776 & 106 & 27 & 5 & 959 \\
\hline 2010 & 3 & 15 & 70 & 1,204 & 184 & 29 & 7 & 1,512 \\
\hline 2011 & - & 14 & 52 & 821 & 124 & 35 & 9 & 1,055 \\
\hline 2012 & 2 & 5 & 70 & 1,099 & 115 & 14 & 8 & 1,313 \\
\hline 2013 & 1 & 12 & 124 & 985 & 65 & 4 & 6 & 1,197 \\
\hline 2014 & 1 & 9 & 166 & 932 & 69 & 3 & 8 & 1,188 \\
\hline 2015 & - & 8 & 163 & 820 & 74 & 12 & 4 & 1,081 \\
\hline 2016 & 1 & 2 & 52 & 247 & 10 & - & - & 312 \\
\hline $\begin{array}{c}\text { Class } \\
\text { total }\end{array}$ & 14 & 84 & 825 & 7,892 & 909 & 171 & 64 & 9,959 \\
\hline \multicolumn{9}{|c|}{ Wild } \\
\hline 2003 & - & - & 6 & 9 & - & - & - & 15 \\
\hline 2004 & - & - & 2 & 15 & - & - & - & 17 \\
\hline 2005 & - & 1 & 1 & 27 & - & 1 & 1 & 31 \\
\hline 2006 & - & - & - & 46 & 1 & 2 & 1 & 50 \\
\hline 2007 & - & 2 & 2 & 54 & 5 & 1 & - & 64 \\
\hline 2008 & 1 & - & 22 & 208 & 5 & 3 & 1 & 240 \\
\hline 2009 & - & 1 & 15 & 223 & 8 & 5 & 1 & 253 \\
\hline 2010 & - & - & 8 & 189 & 12 & 2 & - & 211 \\
\hline 2011 & - & 1 & 2 & 161 & 16 & 2 & 1 & 183 \\
\hline 2012 & - & - & 6 & 155 & 19 & 2 & 2 & 184 \\
\hline 2013 & - & 1 & 23 & 224 & 9 & 2 & - & 259 \\
\hline 2014 & - & 1 & 43 & 187 & 9 & 1 & - & 241 \\
\hline 2015 & - & - & 66 & 165 & 8 & - & - & 239 \\
\hline 2016 & - & - & 24 & 82 & - & 1 & - & 107 \\
\hline $\begin{array}{c}\text { Class } \\
\text { total }\end{array}$ & 1 & 7 & 220 & 1,745 & 92 & 22 & 7 & 2,094 \\
\hline $\begin{array}{c}\text { Grand } \\
\text { total }\end{array}$ & 15 & 91 & 1045 & 9,637 & 1,001 & 193 & 71 & 12,053 \\
\hline
\end{tabular}


Table 11B. Count of observations of pallid sturgeon in each condition class by year and origin (hatchery or wild), using $A$, Shuman $\mathrm{Kn}$ and $B$, Alternative $\mathrm{Kn}$.

[Data availability: Welker and Drobish (2016).]

\begin{tabular}{ccccccccc}
\hline \multirow{2}{*}{ Year } & \multicolumn{7}{c}{ Condition class } & Annual \\
\cline { 2 - 6 } total
\end{tabular}


Table 12A. Percentage of observations of pallid sturgeon in each condition class by year and origin (hatchery or wild), using $A$, Shuman $\mathrm{Kn}$ and $B$, Alternative Kn. [Data availability: Welker and Drobish (2016).]

\begin{tabular}{|c|c|c|c|c|c|c|c|}
\hline \multirow{2}{*}{ Year } & \multicolumn{7}{|c|}{ Condition class } \\
\hline & -3 & -2 & -1 & $\mathbf{0}$ & 1 & 2 & 3 \\
\hline \multicolumn{8}{|c|}{ Hatchery } \\
\hline 2003 & 0.00 & 0.00 & 33.33 & 66.67 & 0.00 & 0.00 & 0.00 \\
\hline 2004 & 2.86 & 2.86 & 20.00 & 74.29 & 0.00 & 0.00 & 0.00 \\
\hline 2005 & 0.00 & 0.00 & 7.45 & 72.34 & 15.96 & 2.13 & 2.13 \\
\hline 2006 & 0.00 & 1.90 & 3.80 & 74.68 & 15.19 & 3.16 & 1.27 \\
\hline 2007 & 0.00 & 1.55 & 5.93 & 68.56 & 17.27 & 4.12 & 2.58 \\
\hline 2008 & 0.48 & 0.64 & 5.14 & 80.39 & 9.00 & 3.86 & 0.48 \\
\hline 2009 & 0.21 & 0.52 & 3.96 & 80.92 & 11.05 & 2.82 & 0.52 \\
\hline 2010 & 0.20 & 0.99 & 4.63 & 79.63 & 12.17 & 1.92 & 0.46 \\
\hline 2011 & 0.00 & 1.33 & 4.93 & 77.82 & 11.75 & 3.32 & 0.85 \\
\hline 2012 & 0.15 & 0.38 & 5.33 & 83.70 & 8.76 & 1.07 & 0.61 \\
\hline 2013 & 0.08 & 1.00 & 10.36 & 82.29 & 5.43 & 0.33 & 0.50 \\
\hline 2014 & 0.08 & 0.76 & 13.97 & 78.45 & 5.81 & 0.25 & 0.67 \\
\hline 2015 & 0.00 & 0.74 & 15.08 & 75.86 & 6.85 & 1.11 & 0.37 \\
\hline 2016 & 0.32 & 0.64 & 16.67 & 79.17 & 3.21 & 0.00 & 0.00 \\
\hline Class total & 0.14 & 0.84 & 8.28 & 79.24 & 9.13 & 1.72 & 0.64 \\
\hline \multicolumn{8}{|c|}{ Wild } \\
\hline 2003 & 0.00 & 0.00 & 40.00 & 60.00 & 0.00 & 0.00 & 0.00 \\
\hline 2004 & 0.00 & 0.00 & 11.76 & 88.24 & 0.00 & 0.00 & 0.00 \\
\hline 2005 & 0.00 & 3.23 & 3.23 & 87.10 & 0.00 & 3.23 & 3.23 \\
\hline 2006 & 0.00 & 0.00 & 0.00 & 92.00 & 2.00 & 4.00 & 2.00 \\
\hline 2007 & 0.00 & 3.13 & 3.13 & 84.38 & 7.81 & 1.56 & 0.00 \\
\hline 2008 & 0.42 & 0.00 & 9.17 & 86.67 & 2.08 & 1.25 & 0.42 \\
\hline 2009 & 0.00 & 0.40 & 5.93 & 88.14 & 3.16 & 1.98 & 0.40 \\
\hline 2010 & 0.00 & 0.00 & 3.79 & 89.57 & 5.69 & 0.95 & 0.00 \\
\hline 2011 & 0.00 & 0.55 & 1.09 & 87.98 & 8.74 & 1.09 & 0.55 \\
\hline 2012 & 0.00 & 0.00 & 3.26 & 84.24 & 10.33 & 1.09 & 1.09 \\
\hline 2013 & 0.00 & 0.39 & 8.88 & 86.49 & 3.47 & 0.77 & 0.00 \\
\hline 2014 & 0.00 & 0.41 & 17.84 & 77.59 & 3.73 & 0.41 & 0.00 \\
\hline 2015 & 0.00 & 0.00 & 27.62 & 69.04 & 3.35 & 0.00 & 0.00 \\
\hline 2016 & 0.00 & 0.00 & 22.43 & 76.64 & 0.00 & 0.93 & 0.00 \\
\hline Class total & 0.12 & 0.75 & 8.67 & 79.96 & 8.30 & 1.60 & 0.59 \\
\hline
\end{tabular}


Table 12B. Percentage of observations of pallid sturgeon in each condition class by year and origin (hatchery or wild), using $A$, Shuman $\mathrm{Kn}$ and $B$, Alternative Kn.

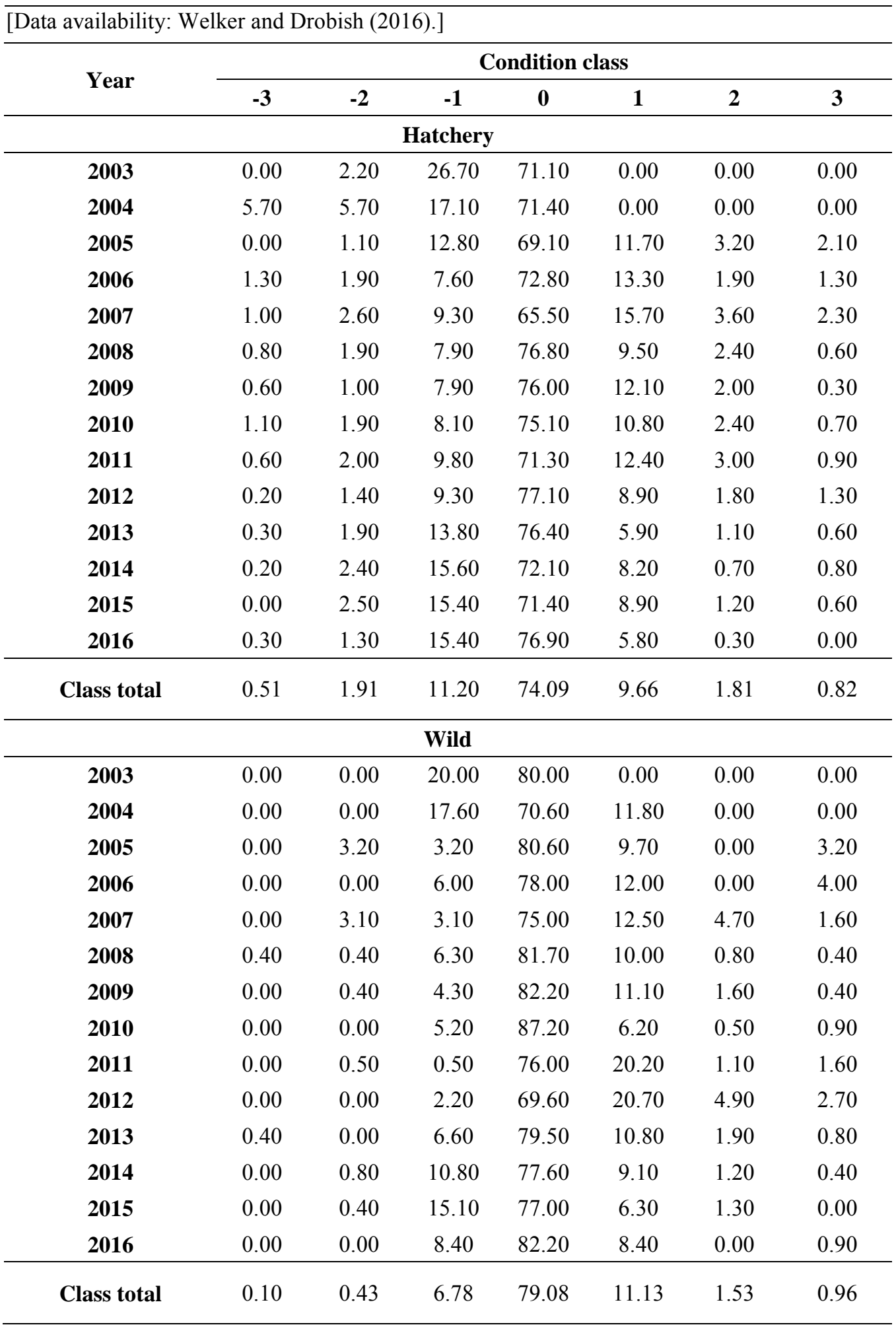


Table 13A. Count of observations of pallid sturgeon in each condition class by origin using $A$, Shuman $\mathrm{Kn}$ and $B$, Alternative $\mathrm{Kn}$.

\begin{tabular}{|c|c|c|c|c|c|c|c|c|}
\hline \multirow{2}{*}{ Hatchery } & \multicolumn{7}{|c|}{ Condition class } & \multirow{2}{*}{ Hatchery total } \\
\hline & -3 & -2 & -1 & $\mathbf{0}$ & 1 & 2 & 3 & \\
\hline Bozeman & - & 3 & 10 & 58 & 11 & 2 & - & 84 \\
\hline Garrison & 3 & 19 & 194 & 1,462 & 126 & 25 & 13 & 1,842 \\
\hline Gavins Point & 5 & 20 & 169 & 1,169 & 128 & 21 & 4 & 1,516 \\
\hline Miles City & 1 & 1 & 11 & 164 & 51 & 7 & 1 & 236 \\
\hline Neosho & 1 & 19 & 132 & 436 & 35 & 6 & 7 & 636 \\
\hline Unknown & 14 & 68 & 513 & 4,084 & 702 & 184 & 79 & 5,644 \\
\hline None/Wild & 2 & 18 & 293 & 1,634 & 103 & 33 & 11 & 2,094 \\
\hline Class total & 26 & 148 & 1,322 & 9,007 & 1,156 & 278 & 115 & 12,052 \\
\hline
\end{tabular}

Table 13B. Count of observations of pallid sturgeon in each condition class by origin using $A$, Shuman $\mathrm{Kn}$ and $B$, Alternative Kn.

[Unknown is hatchery origin, but not traceable to any given hatchery. Data availability: Welker and Drobish (2016).]

\begin{tabular}{|c|c|c|c|c|c|c|c|c|}
\hline \multirow{2}{*}{ Hatchery } & \multicolumn{7}{|c|}{ Condition Class } & \multirow{2}{*}{ Hatchery tota } \\
\hline & -3 & -2 & -1 & $\mathbf{0}$ & 1 & 2 & 3 & \\
\hline \multicolumn{9}{|c|}{ Upper basin } \\
\hline Bozeman & - & 6 & 13 & 57 & 8 & - & - & 84 \\
\hline Garrison & 7 & 15 & 128 & 696 & 69 & 14 & 8 & 937 \\
\hline Gavins Point & 2 & 9 & 77 & 682 & 82 & 13 & 5 & 870 \\
\hline Miles City & 2 & 3 & 14 & 177 & 33 & 5 & 2 & 236 \\
\hline None/Wild & 1 & 3 & 27 & 336 & 62 & 13 & 7 & 449 \\
\hline Unknown & 20 & 50 & 246 & 2,791 & 458 & 87 & 31 & 3,683 \\
\hline Class total & 32 & 86 & 505 & 4,739 & 712 & 132 & 53 & 6,259 \\
\hline \multicolumn{9}{|c|}{ Lower basin } \\
\hline Garrison & 2 & 8 & 69 & 742 & 68 & 10 & 6 & 905 \\
\hline Gavins Point & 4 & 21 & 88 & 479 & 46 & 8 & 1 & 647 \\
\hline Neosho & 8 & 33 & 153 & 394 & 35 & 6 & 7 & 636 \\
\hline Unknown & 1 & 6 & 115 & 1,320 & 171 & 19 & 13 & 1,645 \\
\hline None/Wild & 6 & 45 & 327 & 1,361 & 163 & 37 & 22 & 1,961 \\
\hline Class total & 21 & 113 & 752 & 4,296 & 483 & 80 & 49 & 5,794 \\
\hline
\end{tabular}


Segment 9, in particular, has a high number of low-condition fish (see tables $8 A, B$ ), and was therefore selected for deeper inquiry. Pallid sturgeon condition by capture year, bend, size class, and origin for segment 9 only is shown in tables 14-17.

Table 14A. Count of observations of Segment 9 pallid sturgeon in each condition class by year, using $A$, Shuman $\mathrm{Kn}$ and $B$, Alternative $\mathrm{Kn}$.

\begin{tabular}{|c|c|c|c|c|c|c|c|c|}
\hline \multicolumn{9}{|c|}{ [Data availability: Welker and Drobish (2016).] } \\
\hline \multirow{2}{*}{ Year } & \multicolumn{7}{|c|}{ Condition class } & \multirow{2}{*}{$\begin{array}{c}\text { Annual } \\
\text { total }\end{array}$} \\
\hline & -3 & -2 & -1 & $\mathbf{0}$ & 1 & 2 & 3 & \\
\hline 2003 & - & - & 1 & 2 & - & - & - & 3 \\
\hline 2004 & - & 2 & 2 & 6 & - & - & - & 10 \\
\hline 2005 & - & - & - & 10 & 2 & - & - & 12 \\
\hline 2006 & - & 1 & 1 & 28 & 1 & - & - & 31 \\
\hline 2007 & - & 1 & 1 & 27 & 1 & - & 1 & 31 \\
\hline 2008 & 1 & 1 & 29 & 190 & 13 & - & 1 & 235 \\
\hline 2009 & 1 & 3 & 21 & 261 & 20 & - & - & 306 \\
\hline 2010 & - & 2 & 24 & 209 & 9 & 3 & 2 & 249 \\
\hline 2011 & - & 4 & 30 & 239 & 10 & 3 & 1 & 287 \\
\hline 2012 & - & 1 & 14 & 125 & 20 & 7 & 1 & 168 \\
\hline 2013 & - & - & 47 & 193 & 5 & 2 & - & 247 \\
\hline 2014 & - & 14 & 129 & 172 & 3 & - & 2 & 320 \\
\hline 2015 & - & 17 & 136 & 212 & 8 & 1 & 1 & 375 \\
\hline 2016 & - & 2 & 78 & 143 & 1 & 1 & - & 225 \\
\hline Grand total & 2 & 48 & 513 & 1,817 & 93 & 17 & 9 & 2,499 \\
\hline
\end{tabular}

Table 14B. Count of observations of Segment 9 pallid sturgeon in each condition class by year, using $A$, Shuman $\mathrm{Kn}$ and $B$, Alternative $\mathrm{Kn}$.

\begin{tabular}{|c|c|c|c|c|c|c|c|c|}
\hline \multicolumn{9}{|c|}{ [Data availability: Welker and Drobish (2016).] } \\
\hline \multirow{2}{*}{ Year } & \multicolumn{7}{|c|}{ Condition class } & \multirow{2}{*}{$\begin{array}{c}\text { Annual } \\
\text { total }\end{array}$} \\
\hline & -3 & -2 & -1 & $\mathbf{0}$ & 1 & 2 & 3 & \\
\hline 2003 & - & - & - & 3 & - & - & - & 3 \\
\hline 2004 & 1 & 2 & 1 & 4 & 2 & - & - & 10 \\
\hline 2005 & - & - & 2 & 8 & 2 & - & - & 12 \\
\hline 2006 & 1 & - & 4 & 24 & 2 & - & - & 31 \\
\hline 2007 & 1 & - & - & 27 & 1 & 1 & 1 & 31 \\
\hline 2008 & 1 & 1 & 16 & 193 & 21 & 2 & 1 & 235 \\
\hline 2009 & 2 & 3 & 13 & 256 & 30 & 3 & - & 307 \\
\hline 2010 & 1 & 4 & 18 & 205 & 16 & 2 & 3 & 249 \\
\hline 2011 & - & 8 & 42 & 202 & 31 & 2 & 2 & 287 \\
\hline 2012 & - & 2 & 13 & 104 & 31 & 12 & 6 & 168 \\
\hline 2013 & - & 3 & 45 & 175 & 19 & 4 & 1 & 247 \\
\hline 2014 & - & 13 & 88 & 209 & 7 & 1 & 2 & 320 \\
\hline 2015 & - & 15 & 93 & 256 & 8 & 2 & 1 & 375 \\
\hline 2016 & - & 4 & 40 & 168 & 12 & - & 1 & 225 \\
\hline Grand total & 7 & 55 & 375 & 1,834 & 182 & 29 & 18 & 2,500 \\
\hline
\end{tabular}


There were 78 bends sampled; however, the distribution of catch within the bends was uneven. Bends are numbered sequentially from upstream to downstream. There were 299 fish sampled at bend 1 , whereas bends $32,43,61$, and 72 had only one fish each. There were 20 bends with 30 or more fish. Twenty-nine percent of all fish caught in segment 9 have a Kn more than one standard deviation below the average. The count and percentage of low and normal plus condition fish by bend (for all bends with $\mathrm{N}$ greater than or equal to 30 ) are shown in table 15.

Table 15A. Count and percentage of segment 9 pallid sturgeon by bend (for bends with $\mathrm{N}=>30$ ), using $A$, Shuman $\mathrm{Kn}$ and $B$, Alternative $\mathrm{Kn}$.

\begin{tabular}{cccc}
\hline \multicolumn{4}{c}{ Data availability: Welker and Drobish (2016).] } \\
\hline Bend & Kn $\mathbf{- 1}$ to $\mathbf{- 3}$ SD & Kn 0 to +3 SD & \% Low Kn \\
\hline $\mathbf{1}$ & 42 & 257 & 14 \\
$\mathbf{2}$ & 27 & 111 & 19.6 \\
$\mathbf{3}$ & 50 & 203 & 19.8 \\
$\mathbf{4}$ & 32 & 83 & 27.8 \\
$\mathbf{5}$ & 35 & 58 & 37.6 \\
$\mathbf{6}$ & 9 & 21 & 30 \\
$\mathbf{7}$ & 6 & 28 & 17.6 \\
$\mathbf{9}$ & 30 & 89 & 25.2 \\
$\mathbf{1 0}$ & 14 & 64 & 17.9 \\
$\mathbf{1 1}$ & 41 & 144 & 22.2 \\
$\mathbf{1 2}$ & 28 & 53 & 34.6 \\
$\mathbf{1 3}$ & 33 & 91 & 26.6 \\
$\mathbf{1 4}$ & 12 & 25 & 32.4 \\
$\mathbf{1 5}$ & 22 & 55 & 28.6 \\
$\mathbf{1 6}$ & 8 & 40 & 16.7 \\
$\mathbf{1 7}$ & 18 & 55 & 24.7 \\
$\mathbf{1 8}$ & 10 & 28 & 26.3 \\
$\mathbf{5 2}$ & 25 & 39 & 39.1 \\
$\mathbf{5 5}$ & 10 & 42 & 19.2 \\
$\mathbf{5 7}$ & 5 & 27 & 15.6 \\
\hline
\end{tabular}


Table 15B. Count of segment 9 pallid sturgeon in condition class by bend (for bends with $\mathrm{N}=>30$ ), using Alternative Kn.

\begin{tabular}{cccc}
\hline Bend & Kn -1 to $\mathbf{- 3}$ SD & Kn 0 to +3 SD & \% Low Kn \\
\hline $\mathbf{1}$ & 30 & 269 & 10.0 \\
$\mathbf{3}$ & 36 & 217 & 14.2 \\
$\mathbf{1 1}$ & 40 & 146 & 21.5 \\
$\mathbf{2}$ & 20 & 118 & 14.5 \\
$\mathbf{1 3}$ & 24 & 100 & 19.4 \\
$\mathbf{9}$ & 22 & 97 & 18.5 \\
$\mathbf{4}$ & 26 & 89 & 22.6 \\
$\mathbf{5}$ & 22 & 71 & 23.7 \\
$\mathbf{1 2}$ & 29 & 52 & 35.8 \\
$\mathbf{1 0}$ & 12 & 66 & 15.4 \\
$\mathbf{1 5}$ & 14 & 63 & 18.2 \\
$\mathbf{1 7}$ & 17 & 56 & 23.3 \\
$\mathbf{5 2}$ & 16 & 48 & 25.0 \\
$\mathbf{5 5}$ & 6 & 46 & 11.5 \\
$\mathbf{1 6}$ & 7 & 41 & 14.6 \\
$\mathbf{1 8}$ & 7 & 31 & 18.4 \\
$\mathbf{1 4}$ & 10 & 27 & 27.0 \\
$\mathbf{7}$ & 5 & 29 & 14.7 \\
$\mathbf{5 7}$ & 5 & 27 & 15.6 \\
$\mathbf{6}$ & 8 & 22 & 26.7 \\
\hline
\end{tabular}


Table 16A. Count of observations of Segment 9 pallid sturgeon in condition classes -3 to -1 SD by size class and year, using $A$, Shuman $\mathrm{Kn}$ and $B$, Alternative $\mathrm{Kn}$.

\begin{tabular}{cccccccccccc}
\hline \multicolumn{1}{l}{ [Data availability: Welker and Drobish (2016).] } \\
\cline { 2 - 9 } Year & $\mathbf{2 0 0}$ & $\mathbf{3 0 0}$ & $\mathbf{4 0 0}$ & $\mathbf{5 0 0}$ & $\mathbf{6 0 0}$ & $\mathbf{7 0 0}$ & $\mathbf{8 0 0}$ & $\mathbf{9 0 0}$ & $\mathbf{1 , 0 0 0}$ & $\mathbf{1 , 1 0 0}$ & \multirow{2}{*}{ Annual total } \\
\hline $\mathbf{2 0 0 3}$ & - & - & - & - & - & - & - & - & 1 & - & 1 \\
$\mathbf{2 0 0 4}$ & 1 & 1 & - & 1 & - & - & 1 & - & - & - & 4 \\
$\mathbf{2 0 0 6}$ & 1 & - & - & 1 & - & - & - & - & - & - & 2 \\
$\mathbf{2 0 0 7}$ & - & - & 1 & - & - & - & 1 & - & - & - & 2 \\
$\mathbf{2 0 0 8}$ & - & - & 1 & 7 & 3 & 7 & 4 & 9 & - & - & 31 \\
$\mathbf{2 0 0 9}$ & - & 2 & 2 & 3 & 3 & 2 & 6 & 6 & - & 1 & 25 \\
$\mathbf{2 0 1 0}$ & - & 5 & 5 & 3 & 2 & 5 & 4 & 2 & - & - & 26 \\
$\mathbf{2 0 1 1}$ & - & 17 & 12 & 2 & 1 & 2 & - & - & - & - & 34 \\
$\mathbf{2 0 1 2}$ & 1 & - & 6 & 5 & - & 1 & 1 & 1 & - & - & 15 \\
$\mathbf{2 0 1 3}$ & - & - & 18 & 19 & 6 & - & - & 2 & 1 & 1 & 47 \\
$\mathbf{2 0 1 4}$ & - & - & 10 & 48 & 27 & 19 & 13 & 22 & 3 & 1 & 143 \\
$\mathbf{2 0 1 5}$ & - & 1 & 8 & 31 & 36 & 15 & 23 & 26 & 11 & 2 & 153 \\
$\mathbf{2 0 1 6}$ & - & - & 5 & 13 & 18 & 4 & 10 & 21 & 7 & 2 & 80 \\
\hline $\begin{array}{l}\text { Class } \\
\text { total }\end{array}$ & 3 & 26 & 68 & 133 & 96 & 55 & 63 & 89 & 23 & 7 & 563 \\
\hline
\end{tabular}

Table 16B. Count of observations of Segment 9 pallid sturgeon in condition classes -3 to -1 SD by size class and year, using $A$, Shuman $\mathrm{Kn}$ and $B$, Alternative $\mathrm{Kn}$.

\begin{tabular}{|c|c|c|c|c|c|c|c|c|c|c|c|}
\hline \multicolumn{12}{|c|}{ [Data availability: Welker and Drobish (2016).] } \\
\hline \multirow{2}{*}{ Year } & \multicolumn{10}{|c|}{ Size class } & \multirow{2}{*}{ Annual total } \\
\hline & 200 & 300 & 400 & 500 & 600 & 700 & 800 & 900 & 1,000 & 1,100 & \\
\hline 2004 & 1 & 1 & - & 1 & - & - & 1 & - & - & - & 4 \\
\hline 2005 & - & 2 & - & - & - & - & - & - & - & - & 2 \\
\hline 2006 & 2 & 1 & 1 & 1 & - & - & - & - & - & - & 5 \\
\hline 2007 & - & - & 1 & - & - & - & - & - & - & - & 1 \\
\hline 2008 & - & - & 3 & 6 & 2 & 2 & 3 & 2 & - & - & 18 \\
\hline 2009 & 1 & 4 & 3 & 3 & 2 & - & 1 & 3 & - & 1 & 18 \\
\hline 2010 & 1 & 6 & 9 & 3 & 1 & 3 & - & - & - & - & 23 \\
\hline 2011 & 1 & 27 & 19 & 2 & - & 1 & - & - & - & - & 50 \\
\hline 2012 & 1 & - & 7 & 6 & - & 1 & - & - & - & - & 15 \\
\hline 2013 & - & - & 23 & 20 & 3 & - & - & 1 & - & 1 & 48 \\
\hline 2014 & - & - & 10 & 44 & 25 & 10 & 8 & 4 & - & - & 101 \\
\hline 2015 & - & 2 & 13 & 30 & 30 & 8 & 11 & 8 & 4 & 2 & 108 \\
\hline 2016 & - & - & 7 & 12 & 14 & 4 & 2 & 2 & 3 & - & 44 \\
\hline $\begin{array}{l}\text { Class } \\
\text { total }\end{array}$ & 7 & 43 & 96 & 128 & 77 & 29 & 26 & 20 & 7 & 4 & 437 \\
\hline
\end{tabular}


Table 17A. Count of observations of Segment 9 pallid sturgeon in condition classes -3 to -1 $\mathrm{SD}$ by Origin and Year, using $A$, Shuman $\mathrm{Kn}$ and $B$, Alternative $\mathrm{Kn}$.

[Data availability: Welker and Drobish (2016).]

\begin{tabular}{cccc}
\hline Year & Hatchery & Wild & Annual total \\
\hline $\mathbf{2 0 0 3}$ & - & 1 & 1 \\
$\mathbf{2 0 0 4}$ & 3 & 1 & 4 \\
$\mathbf{2 0 0 6}$ & 2 & - & 2 \\
$\mathbf{2 0 0 7}$ & 1 & 1 & 2 \\
$\mathbf{2 0 0 8}$ & 8 & 23 & 31 \\
$\mathbf{2 0 0 9}$ & 8 & 17 & 25 \\
$\mathbf{2 0 1 0}$ & 14 & 12 & 26 \\
$\mathbf{2 0 1 1}$ & 33 & 1 & 34 \\
$\mathbf{2 0 1 2}$ & 13 & 2 & 15 \\
$\mathbf{2 0 1 3}$ & 45 & 2 & 47 \\
$\mathbf{2 0 1 4}$ & 107 & 36 & 143 \\
$\mathbf{2 0 1 5}$ & 97 & 56 & 153 \\
$\mathbf{2 0 1 6}$ & 54 & 26 & 80 \\
\hline Origin total & 385 & 178 & 563 \\
\hline
\end{tabular}

Table 17B. Count of observations of Segment 9 pallid sturgeon in condition classes 3 to -1 SD by Origin and Year, using $A$, Shuman $\mathrm{Kn}$ and $B$, Alternative Kn.

[Data availability: Welker and Drobish (2016).]

\begin{tabular}{ccccccc}
\hline Year & Garrison & Gavins Point & Neosho & None/Wild & Unknown & Annual total \\
\hline $\mathbf{2 0 0 4}$ & - & 1 & 1 & 1 & 1 & 4 \\
$\mathbf{2 0 0 5}$ & 2 & - & - & - & - & 2 \\
$\mathbf{2 0 0 6}$ & 1 & - & 3 & 1 & - & 5 \\
$\mathbf{2 0 0 7}$ & 1 & - & - & - & - & 1 \\
$\mathbf{2 0 0 8}$ & 5 & - & - & 10 & 3 & 18 \\
$\mathbf{2 0 0 9}$ & 2 & 6 & 1 & 6 & 3 & 18 \\
$\mathbf{2 0 1 0}$ & - & 2 & 9 & 5 & 7 & 23 \\
$\mathbf{2 0 1 1}$ & - & - & 39 & 1 & 10 & 50 \\
$\mathbf{2 0 1 2}$ & - & 1 & 9 & 1 & 4 & 15 \\
$\mathbf{2 0 1 3}$ & 1 & 2 & 21 & 1 & 23 & 48 \\
$\mathbf{2 0 1 4}$ & 7 & 11 & 22 & 16 & 45 & 101 \\
$\mathbf{2 0 1 5}$ & 13 & 14 & 14 & 25 & 42 & 108 \\
$\mathbf{2 0 1 6}$ & 5 & 2 & 6 & 6 & 25 & 44 \\
\hline Origin total & 37 & 39 & 125 & 73 & 163 & 437 \\
\hline
\end{tabular}




\section{Analysis of Covariance for Pallid Sturgeon Weight}

Modeling of covariance of pallid sturgeon weight provides evidence that the intercept and slope of the base LWR varied among years and between basins (figs. 12, 13). The best approximating model of the pallid sturgeon LWR was the global model that allowed the intercept and slope parameter of the base LWR to vary among years and between basins (table 18).

Patterns in basin- and year-specific mean condition were variable (fig. 14). In particular, lower-basin pallid sturgeon post-2011 seemed to be declining in condition. Basin- and yearspecific patterns in predicted weights also varied and showed a decline in weight post-2011 for lower-basin pallid sturgeon (fig. 15). Patterns of year-specific predicted weight and mean condition showed similar patterns for lower-basin pallid sturgeon (fig. 16); however, patterns in year-specific predicted weight and mean condition were inconsistent for upper-basin pallid sturgeon (fig. 15). Evaluating predicted conditions (that is, using model-predicted weights to calculate condition) for 200 to $1,600 \mathrm{~mm}$ pallid sturgeon in the upper basin for 2015 and 2016 showed condition decreasing with length for 2015, whereas condition increased with length in 2016, and catch was dominated by fish $<800 \mathrm{~mm}$ in both years (fig. 17). The relationship of predicted condition with length varied among year and basin, with small fish exhibiting poor condition relative to other sample years regardless of the basin.

Lower-basin pallid sturgeon predicted weight for varying lengths varied among years (fig. 18). Of particular interest were the years since 2011, corresponding to the decline in condition observed by NGPC. The observed decline was replicated using predicted weight; however, a decline in weight was not apparent for pallid sturgeon $<400 \mathrm{~mm}$. Overall, fish lengths evaluated $(600-1200 \mathrm{~mm})$ showed statistically significant decreases in weight after 2012 $(p<0.002)$. 


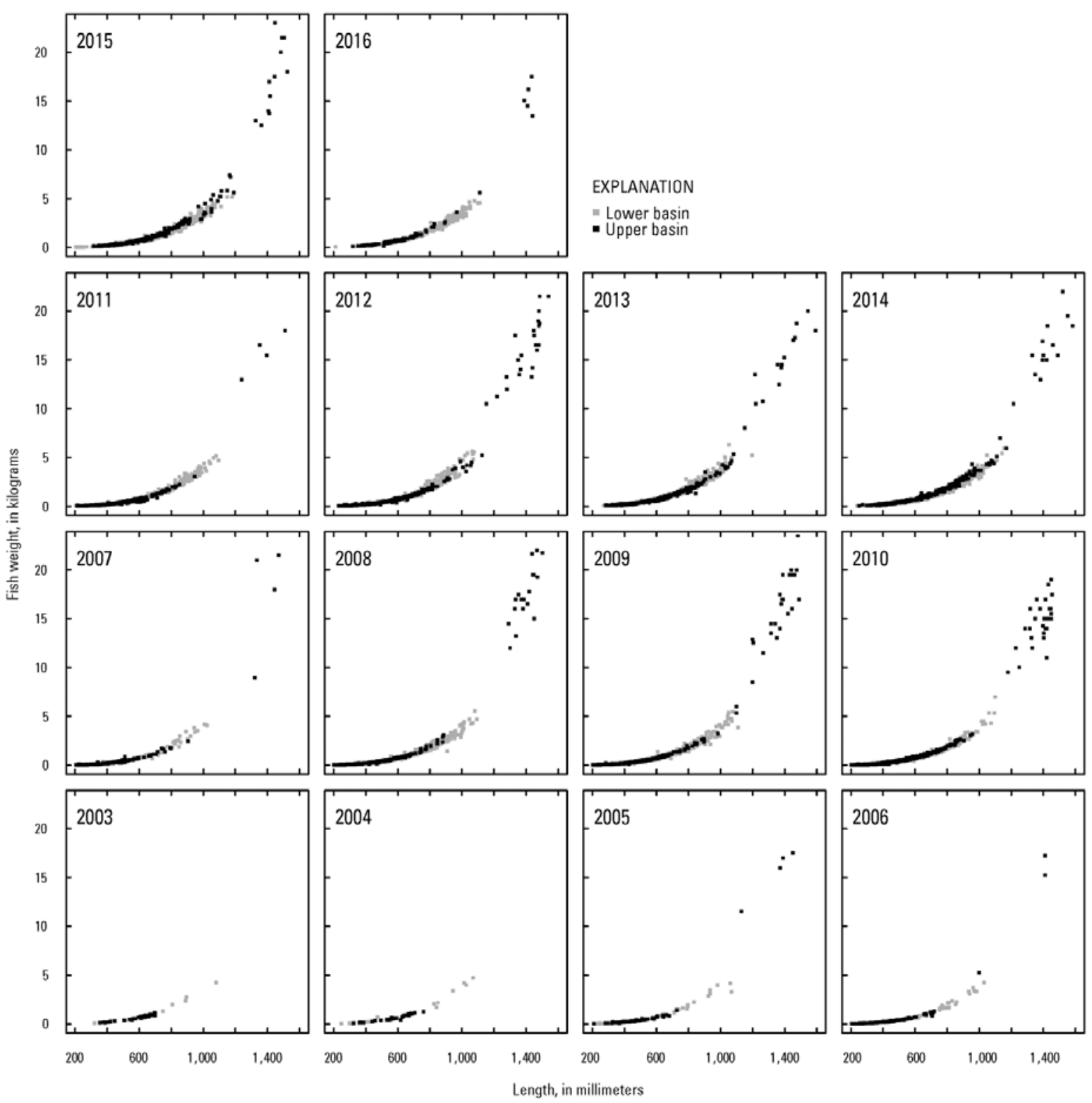

Figure 12. Pallid sturgeon weight (y-axis) and length ( $x$-axis) for 2003 to 2016 grouped by Missouri River Basin. Data availability: Welker and Drobish (2016). 

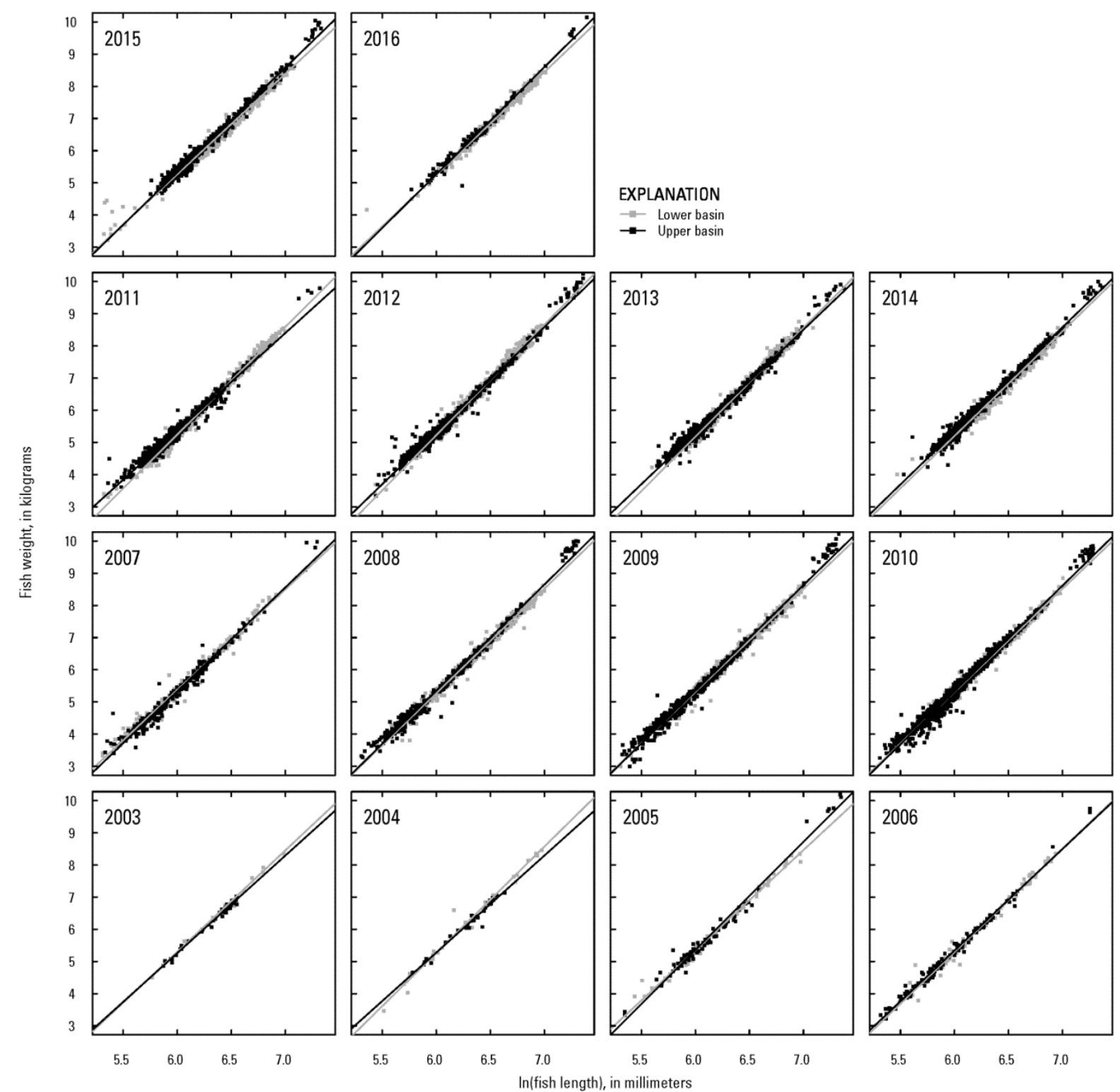

Figure 13. Plot of weight (y-axis) and length (x-axis) on log scale for pallid Sturgeon captured in Missouri River basins. Lines represent best fit linear models predicting weight from length for data in each panel and group. Data availability: Welker and Drobish (2016). 
Table 18. Model selection results for candidate length-weight models fit to upper and lower Missouri River basin pallid sturgeon from 2003 to 2016.

\begin{tabular}{|c|c|c|c|c|c|c|}
\hline Model & $\begin{array}{l}\text { Number of } \\
\text { parameters }\end{array}$ & Ln(likelihood) & AICc & $\triangle \mathrm{AICc}$ & $\begin{array}{l}\text { Model } \\
\text { weight }\end{array}$ & $\begin{array}{c}\text { Cumulative } \\
\text { model weight }\end{array}$ \\
\hline $\begin{array}{c}\text { In(length)+year+basin+ } \\
\text { ln(length)*basin+ } \\
\text { ln(length)*year+basin*year+ } \\
\text { ln(length)*basin*year }\end{array}$ & 57 & 7986 & -15858 & 0 & 1 & 0.999 \\
\hline In(length)+year+year*basin & 30 & 7689 & -15318 & 539 & $<0.001$ & 1 \\
\hline $\begin{array}{l}\text { In(length)+year+basin+ } \\
\text { ln(length)*year }\end{array}$ & 30 & 7658 & -15256 & 602 & $<0.001$ & 1 \\
\hline $\begin{array}{l}\text { In(length) +year++basin+ } \\
\text { ln(length)*basin }\end{array}$ & 18 & 7560 & -15084 & 773 & $<0.001$ & 1 \\
\hline In(length)+year+basin & 17 & 7553 & -15072 & 786 & $<0.001$ & 1 \\
\hline In(length)+year+llen*year & 29 & 7463 & -14868 & 989 & $<0.001$ & 1 \\
\hline In(length)+basin+llen*basin & 5 & 7359 & -14708 & 1149 & $<0.001$ & 1 \\
\hline In(length)+basin & 4 & 7354 & -14700 & 1157 & $<0.001$ & 1 \\
\hline In(length)+year & 16 & 7358 & -14684 & 1174 & $<0.001$ & 1 \\
\hline ln(length) & 3 & 7213 & -14421 & 1437 & $<0.001$ & 1 \\
\hline
\end{tabular}




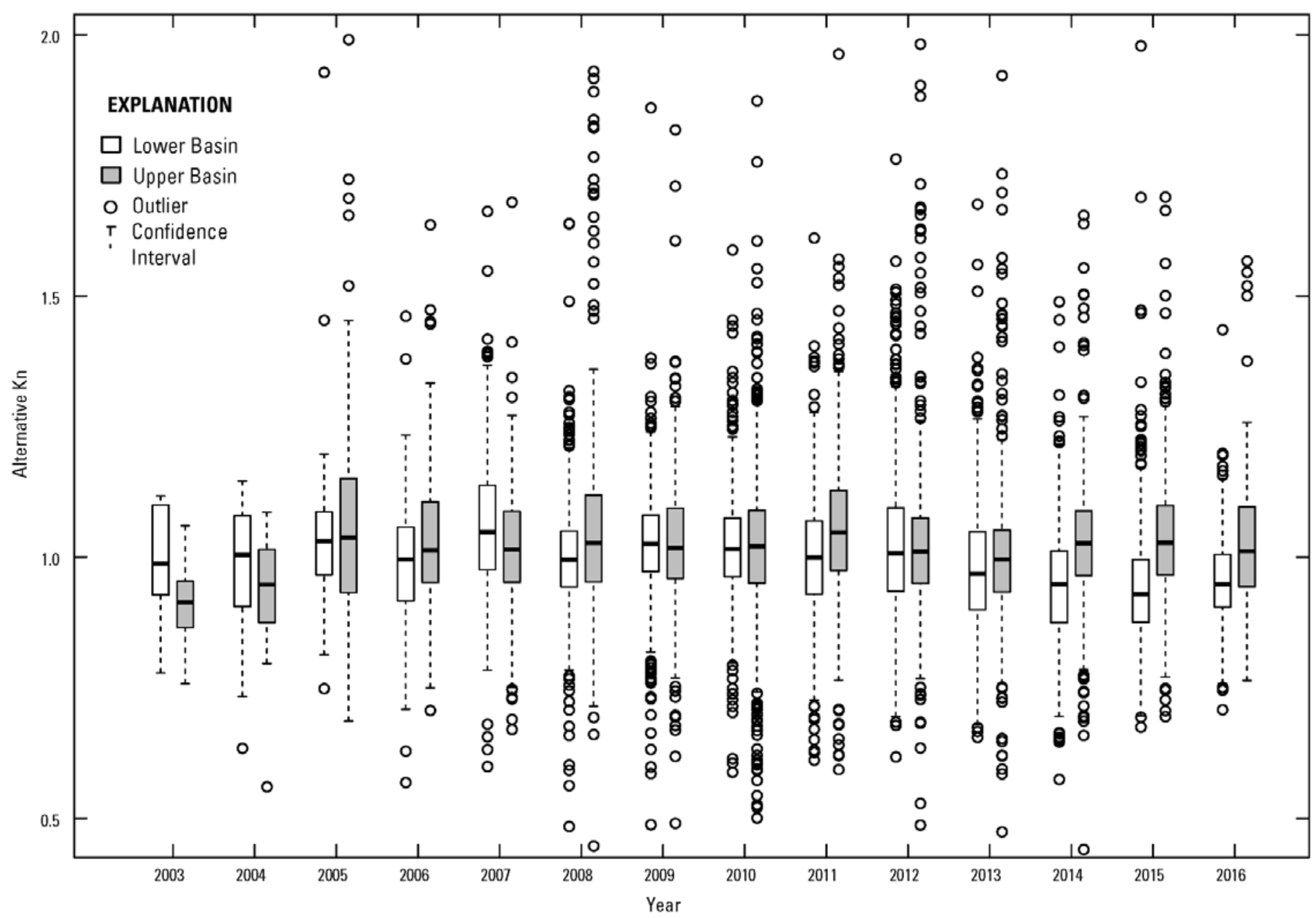

Figure 14. Plot of condition (y-axis) and year (x-axis) for pallid sturgeon captured in the upper and lower basins. Y-axis scale restricted to 2 for figure clarity and 261 observations not shown because they exceeded plot region. Data availability: Welker and Drobish (2016). 

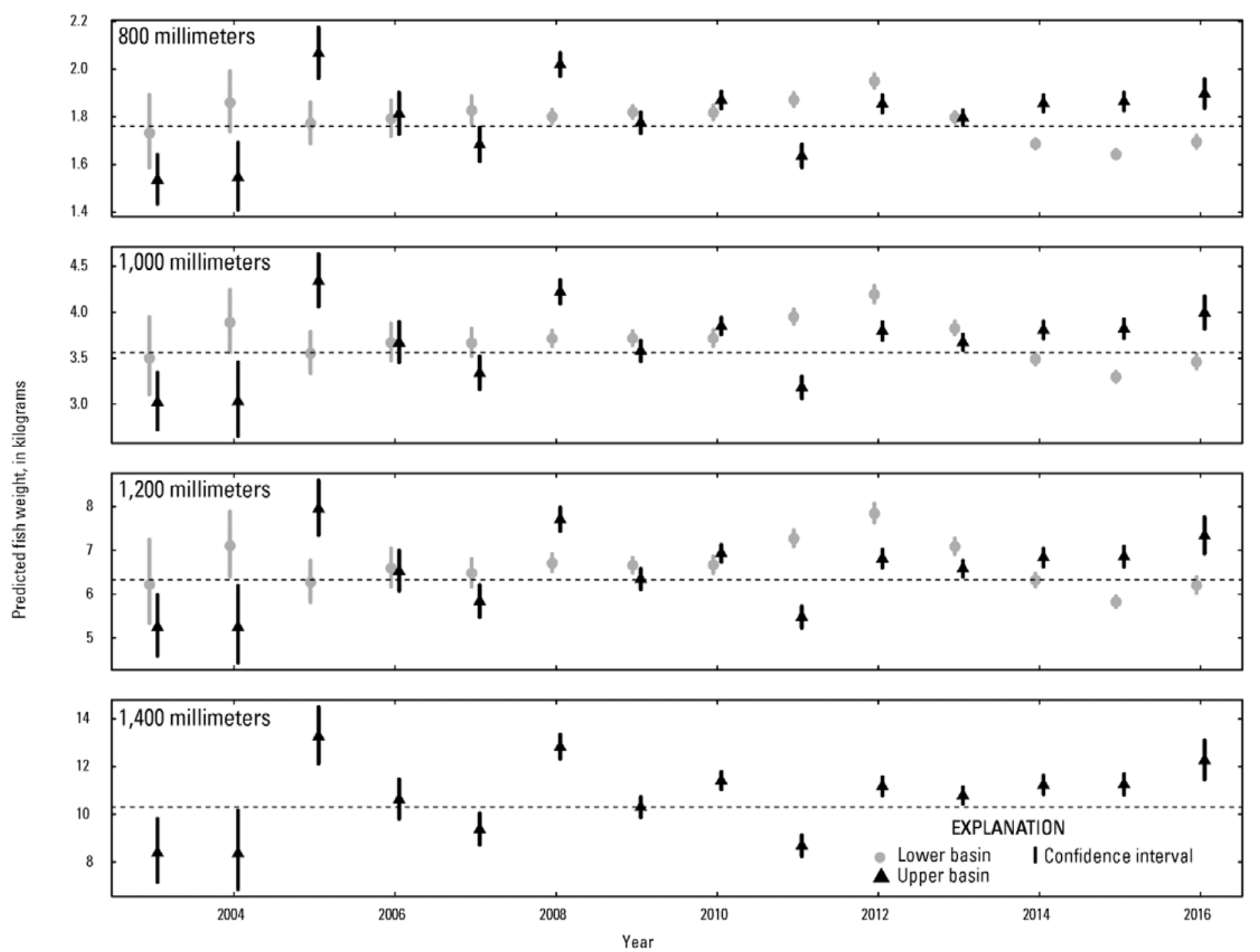

Figure 15. Plot of estimated weight and year for pallid sturgeon lengths of $800,1,000,1,200$, and 1,400 mm in the Missouri River basin. Lowerbasin estimates were not included for pallid sturgeon exceeding $1,200 \mathrm{~mm}$ because they were not observed. Vertical lines denote $95-$ percent confidence intervals. The horizontal dotted line represents the length-specific standard weight used to calculate pallid sturgeon condition. Data availability: Welker and Drobish (2016). 

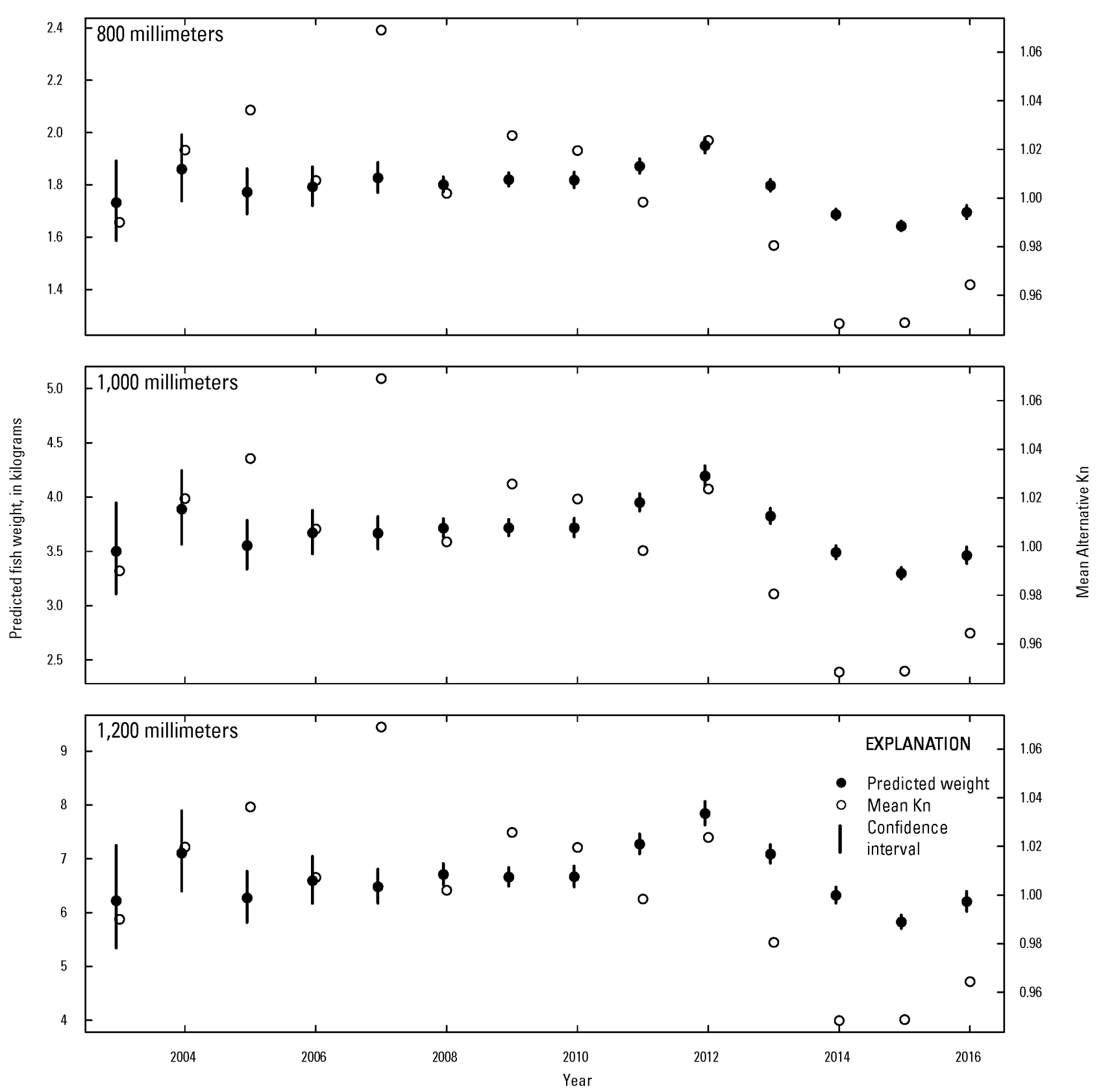

Figure 16. Estimated weight for varying length of Lower Missouri River basin pallid sturgeon among years. Open circles denote year-specific mean pallid sturgeon condition values for lower Missouri River Basin pallid sturgeon (secondary y-axis). Data availability: Welker and Drobish (2016). 


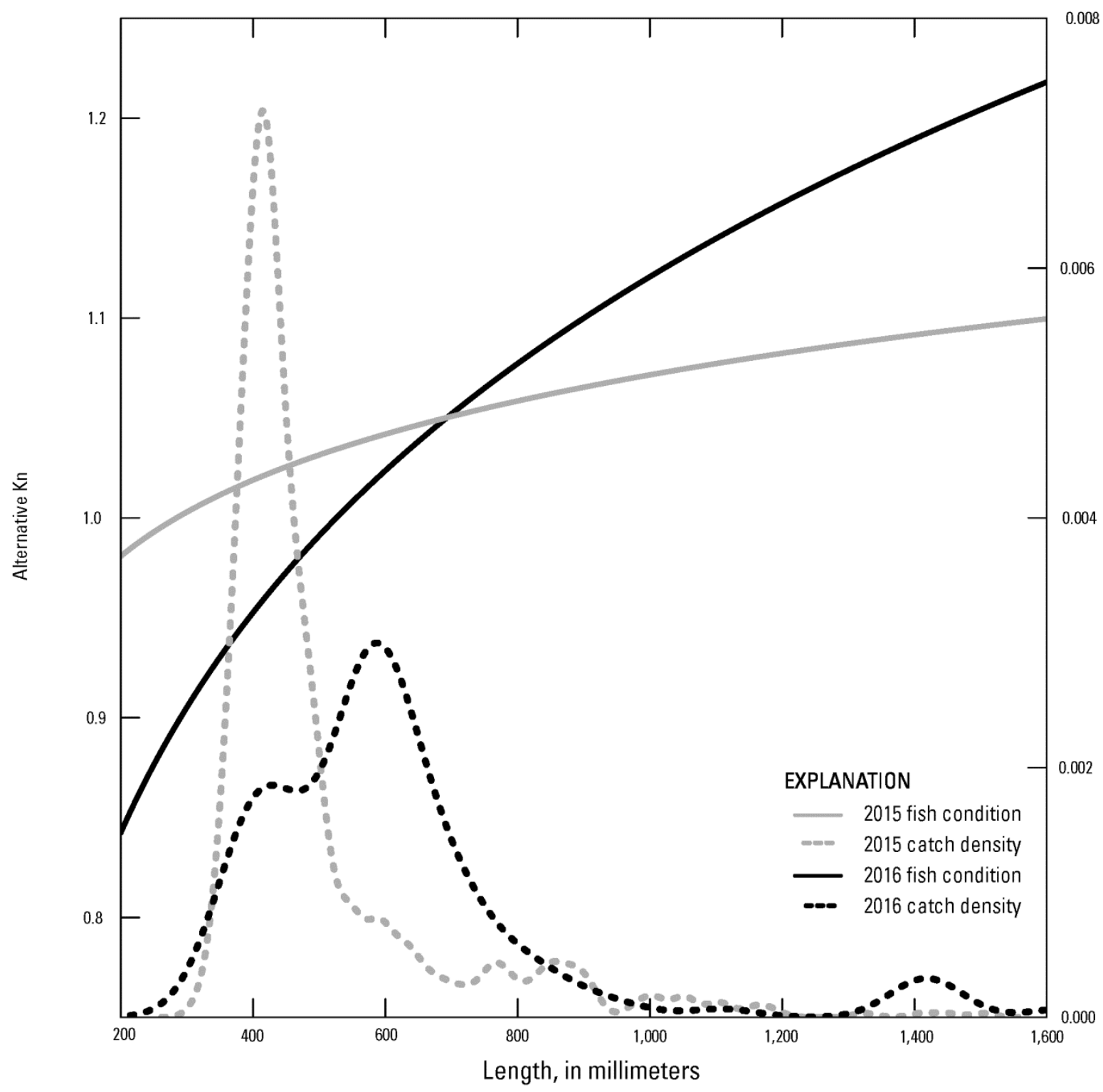

Figure 17. Length-specific condition values for upper Missouri River basin pallid sturgeon calculated from predicted weights for 2015 and 2016. The dotted lines illustrate density of observations (that is, relative catch). Data availability: Welker and Drobish (2016). 


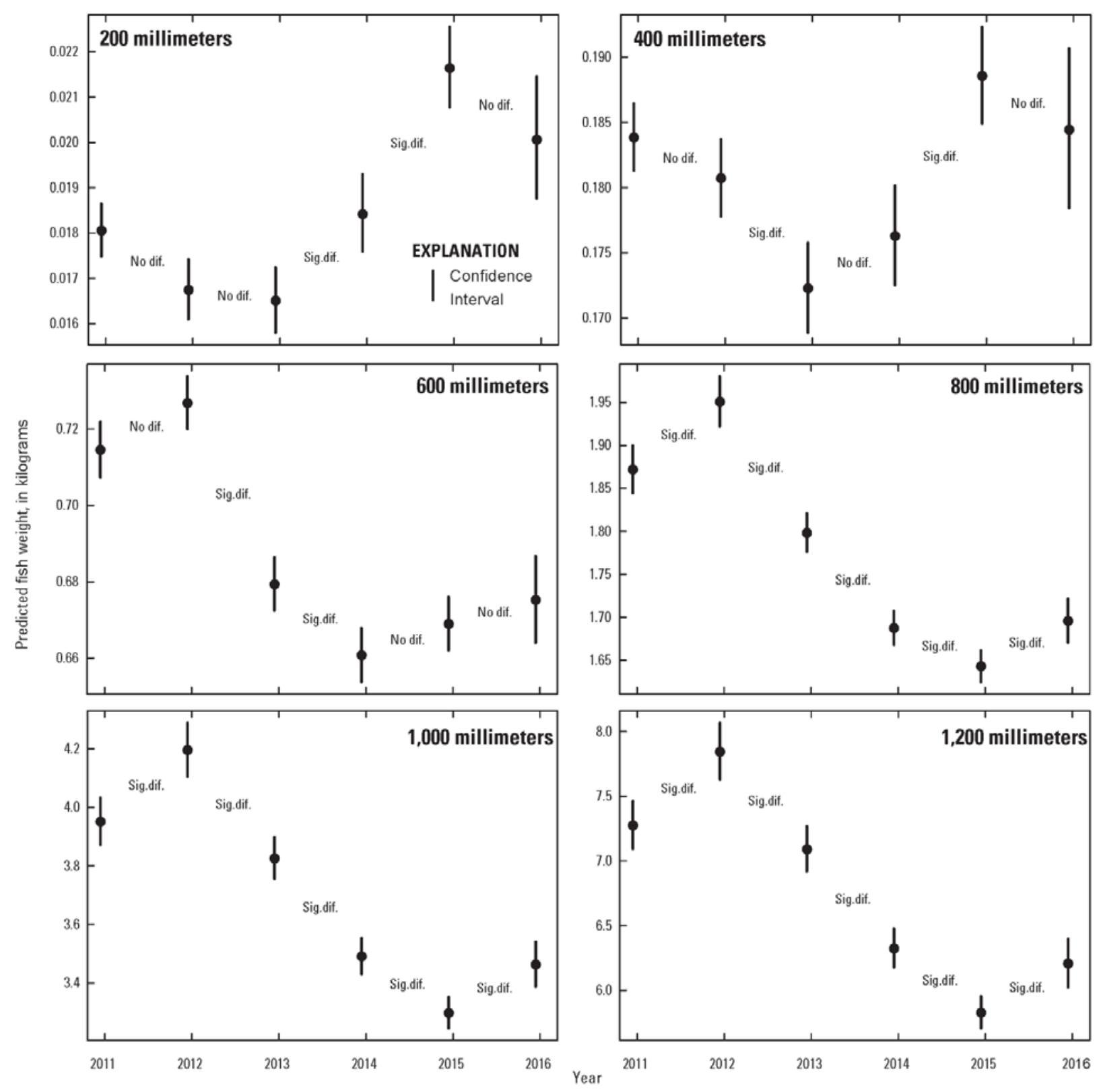

Figure 18. Model estimated weights for Lower Missouri River basin pallid sturgeon from 2011 to 2016. Vertical lines denote 95-percent confidence intervals for model predicted weight. The text between points denotes whether the previous year's weight was statistically different. A p-value of 0.002 was used to determine the significance of between-year comparisons. Data availability: Welker and Drobish (2016). 


\section{Discussion—Do Lower Missouri River Pallid Sturgeon Have Declining Condition?}

The following sections include discussions of trends in condition based on Shuman $\mathrm{Kn}$, Alternative Kn, and the ANCOVA to predict weights independent of a reference LWR.

\section{Trends Based on Condition Indices}

Relative condition is a standard metric used in fisheries management but has limitations. Nevertheless, because of its previous and widespread usage, we based part of our analysis on relative condition. We used Shuman and others (2011) LWR for the first part of the analysis; for the second part we created an alternative Kn (Alternative Kn) using all available data. We mitigated effects of bias by limiting the data range used and removing data points that were obvious field or transcription errors. We reduced the dataset by removing 20 small, robust fish that seemed to be erroneous, which increased the standard deviation and decreased the mean slightly, thus ensuring that we used the least conservative parameters to denote low, normal, and robust fish.

The data indicate that, since the start of sampling in 2003, average pallid sturgeon condition has consistently been higher in the upper basin using Alternative Kn (figs. 8A, B). Condition, in the upper and lower basins, held relatively steady from 2005 until 2011 but began to decline in 2012 (figs. 8A, B; 9A, B). The upper-basin average increased in 2013 and 2014 but dropped again in 2016. The Alternative Kn formulation shows less decline in the upper basin. The lower basin, using Shuman and the Alternative Kn, had a substantial drop in 2013-15, follow by a modest recovery in 2016; however, the absolute value of these drops is small and has not been shown to have biological significance.

The individual view (percentage of fish in low, normal, or robust conditions) shows a more complex story. There have been low-condition fish in both basins since sampling began in 2003 (tables 5, 6). The proportion of fish in low condition has been higher in the lower basin than in the upper basin and has increased since 2013; however, this decrease in condition is not a universal feature, as fish in the upper and lower basins have been captured in robust condition in all years.

Using Shuman Kn, a greater percentage of fish in the lower basin are designated as being in low condition compared to the upper basin; there have been 1,039 of 5,794 (17.93 percent) fish in low condition from the lower basin, as compared to 457 of 6,258 (7.03 percent) fish sampled in the upper basin. Using the Alternative $\mathrm{Kn}$, the percentage of fish in low condition is similar between the upper and lower basins; there are 886 (15.29 percent) in the lower basin and 623 (10.75 percent) in the upper basin. By year, the percent of fish in low condition has held steady in the upper basin since full-scale sampling began in 2005. In the lower basin, using the Shuman Kn, the percent of fish in low condition began to increase in 2012 and accelerated rapidly in 2013, rising to 36.9 percent in 2014 and 39.5 percent in 2015 , but has declined slightly to 32.8 percent so far in 2016 (table $6 A, B$ ). Using the alternative formulation, the upper basin showed little change in probability of low-condition fish, whereas the lower basin still showed the same trend as the Shuman formulation, but at lower percentages (28.1 percent in 2014, 28.5 percent in 2015, and only 16.2 percent in 2016). It is notable that the number of fish captured in 2016 was substantially below recent sampling years (table 1), as it reflects only a half-year of sampling.

Location (river segment) has an effect on the probability of being in low condition. In this analysis, we grouped segments 5 and 6 with the upper river segments $(2,3$, and 4$)$ for convenience and because most of the fish in segments 5 and 6 were stocked from upper river 
progeny. We recognize that factors affecting fish condition may vary among these segments. Disregarding segments with low sample size, the upper river segments 5 and 6 (Fort Randall dam to the Niobrara River confluence) have a higher percentage of the population in low condition compared to the rest of the basin. In the lower river, segment 9 (Platte River to the Kansas River) has a higher probability of having fish in low condition compared to the rest of the basin (tables $7 A, B ; 8 A, B)$.

Size class, for those classes with a large sample size, has little effect on the probability of low condition in either the upper or lower basin. In the upper basin, there is an increase in the probability of low condition in the $600-699 \mathrm{~mm}$ size class. In the lower basin there is a substantial increase in the probability of low condition in the 1,100-1,199 class; however, sample size is small. In the upper basin, small size increases the probability of being in robust condition; the effect is not apparent in the lower basin. In general, increasing size decreases the probability of being in robust condition and increases the probability of being in low condition (tables $9 A, B ; 10 A, B)$.

Origin, in terms of hatchery compared to wild-produced, had little effect on the probability of being in low condition from 2005 to 2012. From 2014 to 2016, being of wild origin increased the probability of being in low condition by 1.4 times (average probability of 16.1 percent for hatchery origin, compared to 22.8 percent probability for wild-origin fish); however, this trend was confounded by wild-origin fish being more likely to be large (tables $11 A, B ; 12 A, B)$.

Basin, year, and segment affect the probability of being in low condition. Size class and origin have a low effect, most of which is probably confounded by historical trends of low or no natural recruitment, resulting in wild-origin fish being larger and older. In general, a fish sampled in the lower basin, in segment 9, and from 2012 to 2016 had much higher probability of being in low condition than any other combination.

Within segment 9, we looked at year (table 14A, B), bend (table 15A, B), size class (table 16), and origin (table $17 A, B$ ). Segment 9 includes some of the most intensive sampling because it includes the annual broodstock collection carried out by NGPC in bends $1-17$. The effect of year is notable; from 2013 to 2016, there are high counts of low-condition fish, including larger numbers of fish in increasingly poor condition. There have been 48 fish at greater than 2 standard deviations below the mean recorded in this segment; 31 of them occurred in 2014 and 2015. Bend has an effect, but the effect is not consistent throughout the segment and the effect is confounded by uneven effort. Bend 52 has the highest percentage of low-condition fish, but the percentages of low-condition fish in bends 55 and 57 are below the segment average. Bends 5 and 6 are above the segment average, but bends 2, 3, and 4 are below. Size class shows a trend towards larger fish being in low condition from 2014 to 2016, whereas the proportion of hatchery to wild-origin fish has risen over the years. Although the distribution of low-condition fish within segment 9 is highly non-uniform and clustered in specific areas, the data are not adequate to discern whether low-condition fish are more likely to be captured in specific bends or whether those bends might have geographically distinct features responsible for poor condition. In general, the spatial effect of bends is confounded by variable capture effort and the large potential home range of this fish, which spans many bends or even many segments.

\section{Analysis of Covariance Approach}

The predicted weight analysis based on ANCOVA complements the mean condition analysis. Directly modeling weight as a function of length as well as geographic and temporal 
variables provided similar results to the condition analysis and provided additional clarification about patterns in pallid sturgeon condition. Additionally, the length-weight analysis was robust to analytical issues associated with fish condition. Specifically, heterogeneity among slopes of year- and basin-specific LWRs can obfuscate condition patterns, a phenomenon identified in this analysis as well as by Cade and others (2011).

Patterns in population-level mean condition calculated using the alternative formulation followed patterns in predicted weight, at least for pallid sturgeon $>800 \mathrm{~mm}$ in length (that is, fish that have attained reproductive size). Discrepancies in weight-condition patterns were associated with the covariation of condition with length, which in turn was affected by the density of catch (where smaller fish are captured with higher frequency than larger, presumably older, fish). Specifically, if condition was low for smaller pallid sturgeon in a given year, the population-level mean condition was, in turn, decreased because the catch was dominated by smaller fish. This phenomenon was illustrated in figure 17 where pallid sturgeon $<800 \mathrm{~mm}$ had higher condition in 2015 relative to 2016. Despite pallid sturgeon $>800 \mathrm{~mm}$ having a higher condition in 2016 relative to 2015, most of the fish captured were $<800 \mathrm{~mm}$, which had a lower condition relative to 2015 and therefore the population-level mean condition was higher in 2015 relative to 2016. Variation in condition in this example is influenced by heterogeneity in the intercept and slope of the LWR.

Comparing predicted weights at varying lengths provided an approach to evaluate changes in weight between basins and among years. The length-weight analysis also provided some additional resolution in whether there have been declines in lower-basin pallid sturgeon weight during recent years. Of particular interest were the differences in predicted weight patterns among pallid sturgeon lengths. Specifically, predicted weights for lower-basin pallid sturgeon 200 or $400 \mathrm{~mm}$ in length were not similar to patterns for pallid sturgeon 600,800 , 1,000 , and $1,200 \mathrm{~mm}$ in length. Other researchers have reported that pallid sturgeon transition from feeding on invertebrates to piscivory between 400 and $600 \mathrm{~mm}$ (Grohs and others, 2009; French and others, 2013); this transition may require further consideration in assessing fish condition.

Heterogeneity of intercept and slope estimates due to geographic and temporal variation can create issues when comparing fish condition among time and space; however, when model parameters (intercepts and slopes) are viewed hierarchically, variability in intercepts and slopes of the LWR can be related to covariates using hierarchical linear models. For example, Ebersole and others (2009) used varying covariates at the habitat unit, stream reach, and stream segment level to explain differences in juvenile coho salmon (Oncorhynchus kisutch) weights through space and time. Similarly, Deschenes and Rodriguez (2007) used a hierarchical linear model of length and weight for a stream-dwelling salmonid to explain variability in weight using covariates from differing spatial resolutions. A hierarchical analysis of length and weight using a hierarchical linear model could be used to potentially identify factors associated with variability of length-specific pallid sturgeon weight.

\section{Summary and Consequences of Declining Condition}

With respect to question 1, we can answer with a qualified yes, there is evidence that some size classes of pallid sturgeon, in some reaches, are in poor and declining condition in the Lower Missouri River. Our confidence is high that in recent years, in the lower river, many fish were in low or declining condition, depending on year and segment. It is notable, however, that not all fish are in poor condition and that the trend may have leveled out by 2016. Variation in 
condition indicates that whatever the cause is, it has not had an overwhelming effect on the population, and therefore it is to be expected that the mechanism or mechanisms are unclear at this time. In addition, it is not known what proportion of fish would need to be in low condition to have a substantive effect on the population; the proportion of fish in good condition may be sufficient to maintain the population. Nevertheless, the steep decline in condition and weight in the lower river 2012-15 remains a concern because future trends and the cause are unknown.

Declining condition of juvenile and adult lower-basin pallid sturgeon may have individual and population-level consequences. Survival, growth, and condition are considered primary biotic responses in the conceptual ecological models developed for pallid sturgeon (Jacobson, Parsley, and others, 2015). Habitat suitability, food availability, competition, and intersex were identified during CEM development as factors with varying uncertainty and importance affecting growth and condition, which in turn affects secondary biotic responses identified in the CEMs. Specifically, growth and condition were hypothesized to affect two pallid sturgeon secondary biotic responses: (1) the probability of producing viable embryos, and (2) survival to adult for juveniles. Condition may also affect additional biotic responses not explicitly linked in the CEMs, such as movement and migration.

The effect of condition on the probability of producing viable embryos has not been examined for sturgeon or other freshwater species. Most studies have evaluated fish size because it relates length or weight to fecundity. Limited available data on fecundity for Missouri River pallid sturgeon indicated no significant relationship to Kn (Steffensen and Mestl, 2016). In general, fecundity increases with length, weight, or age, but the relationship varies presumably due to condition and energetic constraints. Rideout and Morgan (2010) determined that relative body weight, an index of body condition, was a poor predictor of fecundity in marine fish species; however, body weight alone was more related to fecundity than other predictors evaluated for a riverine fish in Bangladesh (Hossain and others, 2012). Koops and others (2013) indicated that maternal condition positively influences the number of eggs spawned in fishes; however, determining whether fecundity increases are due to fish weighing more for a given length or weighing more because of increased gonad mass is uncertain. Further confounding prediction of the effect of fish condition on fecundity is that it cannot be evaluated reliably because length and weight are correlated. One potential approach to developing a relationship that accounts for the effect of length and condition on fecundity is to use weight as an offset in a general linear model (Dick, 2009). This approach predicts the number of eggs per mass of fish. A unique property of this relationship is that fecundity can decrease with increasing length; however, this phenomenon is not necessarily counterintuitive because fecundity can decline with age as a fish invests in fewer but larger eggs (Nitschke and others, 2001).

Consequences of poor condition on survival are not limited to life stages identified in the CEMs. In particular, adult pallid sturgeon may be susceptible to decreased survival when energetic reserves are depleted, leading to poor condition. Pallid sturgeon, like most long-lived species, are typified by high survival rates exceeding 90 percent for pallid sturgeon escaping early life stage demographic bottlenecks (Hadley and Rotella, 2009; Rotella and Hadley, 2010; Steffensen and others, 2010). The consequence of condition on individual pallid sturgeon survival is uncertain; however, capture-mark-recapture data may provide an approach to estimate the effect of individual fish condition as a covariate affecting survival. For example, Rotella and Hadley (2010) used individual disease status of recaptured pallid sturgeon to estimate a negative effect of fin curl on survival of yearling pallid sturgeon stocked in the Missouri River upstream from Fort Peck Lake. Similarly, the same study estimated a negative effect of iridovirus on 
individual survival. Relating individual fish condition to survival presents a challenge because condition varies over time unlike the presence of fin curl status, which does not change over time.

A Cormack-Jolly-Seber (CJS) model provides an approach to estimate the effect of condition on survival, but covariates are limited to using initial condition in estimation programs such as Program Mark (White and Burnham, 1999); however, a multistate CJS model can account for changes in condition, where condition is defined as a state similar to low, medium, or high. For example, Howell and others (2016) used this approach to estimate the effect of bull trout (Salvelinus confluentus) growth on survival. Alternatively, Bayesian approaches to fit a CJS can potentially be used to estimate growth and condition over time. These approaches can use estimates of condition as a covariate to predict individual survival; however, applying Bayesian analysis may present a challenge when disentangling the length and weight growth processes and estimating condition and its relationship to survival.

Poor condition may also affect the age that an individual pallid sturgeon becomes sexually mature and the duration an individual pallid sturgeon remains in a recrudescent stage after spawning. Despite age or size at sexual maturity and spawning interval being commonly used in population viability analyses (PVA), there are no published studies evaluating the effect of condition on age or size at maturity or duration of spawning interval for sturgeon. In most PVA studies, a fixed interval for spawning is assumed (Jager and others, 2007; Steffensen and others, 2013a); however, Wildhaber, Albers, and others (2015) applied uncertainty to the probability that a female would spawn again, and Jager and others (2007) evaluated a scenario where spawning interval was a function of sturgeon density. Similarly, the size or age an individual pallid sturgeon becomes sexually mature (that is, spawns for the first time) is treated as a fixed parameter, when it is more likely related to having sufficient energetic reserves for the growth of reproductive tissues. Although the effect of fish condition on sexual maturity and spawning interval has not been assessed in sturgeon or other fish species, factors that potentially increase spawning interval are likely to have a negative effect on the population by reducing the lifetime spawning potential of individual fish, unless demographic compensation occurs.

Small-scale daily movements and large-scale spawning migrations both require stored energy. It is likely that poor-condition fish would have depleted energetic stores that may minimize or preclude movements, which would have a negative consequence at the individual level. Although this relationship has not been established for pallid sturgeon, the effect of growth and condition on movement has been evaluated in other fish species. For example, Heim and others (2016) determined that European grayling (Thymallus thymallus) in better condition began migrating earlier than smaller or poor-condition grayling. Slotte (1999) determined that Norwegian spring spawning herring (Clupea harengus) may not fully migrate to natal spawning areas to offset progeny survival and physiological constraints due to poor condition. Similar negative consequences of poor body condition may limit pallid sturgeon migration timing and extent. Specifically, pallid sturgeon, like other sturgeon species, are known to migrate hundreds of kilometers to upstream spawning areas and form spawning aggregations. Thus, if poor body condition decreases the likelihood of a pallid sturgeon reaching a spawning area at the same time as other pallid sturgeon, or increases probability of selecting unsuitable areas, spawning may not be as successful because it is believed that larger spawning aggregations increase spawning success (DeLonay and others, 2009). 


\section{Question 2-What are Likely Causes of Declining Pallid Sturgeon Condition?}

The second charge to the team was to evaluate causes for declining condition in the event that declining condition was confirmed or determined to be likely. Many potential causes can be hypothesized for decline in fish condition. The information needed to evaluate the hypotheses is highly variable in quality, and in all cases the optimal information is not available. The team developed a set of hypotheses for causes of declining condition but it has not been possible to converge on any specific hypothesis with high confidence. In the following sections, we present information bearing on the causal hypotheses when information is available. We emphasize that the information presented is intended to provide an initial evaluation to determine whether the causal hypothesis qualifies for additional evaluation. The data are not being used to accept or reject hypotheses. We organize the hypotheses into three main categories.

\section{Hypothesis-Pallid Sturgeon Have Health Problems that Limit Condition}

This hypothesis holds that either hatchery-origin or wild-origin pallid sturgeon may have health conditions that result in ineffective foraging or metabolism. A specific subhypothesis holds that some stocked fish may have acquired diseases in the hatchery that diminish their ability to feed in the wild; moreover, such impairment may be more critical at the transition to piscivory when foraging behaviors need to change. Some information exists to relate fish survival to hatchery conditions wherein fin curl and iridovirus were related to decreased survival probability for fish stocked upstream from Fort Peck Lake (Rotella and Hadley, 2010). Critical information for attributing disease to specific stocked fish is not available or is ambiguous for the lower basin. We discuss the need to improve tracking of hatchery history and disease status in the "Discussion—Future Directions in Assessing Pallid Sturgeon Condition" section.

\section{Hypothesis-There is Too Much Inter- and Intraspecific Competition for Food or Space Resources}

Competition between organisms in nature is a primary driving force that organizes ecological communities (Persson, 1997; Svanbäck and others, 2008) and can be an important limiting factor of population size and biomass (Webster and Hixon, 2000; Kaspersson and others, 2013). Organisms like pallid sturgeon compete for the resources they need to grow, survive, and reproduce in their native environment. Competition for a limiting resource in an area can result in lowered growth, fecundity, or survival in individuals (Clarke, 1992; Keeley, 2001) and lead to reduced population size and viability (Forero and others, 2002; Einum and others, 2008). Identifying and quantitatively measuring competition in the natural world is distinctly difficult. This makes it challenging to make inferences regarding the mechanisms and effects of competition on individuals and populations. For example, competition for resources can occur between individuals of the same species (intraspecific competition; that is, pallid sturgeon competing with pallid sturgeon) or between different species (interspecific competition; for example, pallid sturgeon competing with shovelnose sturgeon) and can occur through direct (organisms competing directly for the same resource) or indirect mechanisms (organisms using the same resource, but not interacting).

In the Missouri River, pallid sturgeon theoretically compete for food and habitat with other pallid sturgeon and other species that share the same resource needs. At a functional level, competition may be stage structured (for example, juvenile, adult) along a variety of resource 
gradients (for example, macroinvertebrates, prey fish). Studies that identify resource competition between pallid sturgeon and other organisms are generally absent; however, correlation analysis can be used to infer that competition may be occurring (Mittelbach, 1988; Osenberg and others, 1994; Svanbäck and Bolnick, 2007; Eloranta and others, 2016). We hypothesize that a strong negative correlation between pallid sturgeon condition and catch per unit effort of potential sturgeon (pallid and shovelnose) competitors can be used to infer that intraspecific competition and (or) interspecific competition may be occurring at a level that reduces resource availability, with the potential to result in reduced pallid sturgeon condition. Although correlation does not necessarily imply causation, a strong correlation can be used to identify additional hypotheses, confounding factors, or additional research needs to characterize cause and effect relationships.

Pallid sturgeon have been determined to shift from a diet dominated by aquatic invertebrates to one primarily consisting of fish during the later juvenile to adult life stages when they exceed approximately $600 \mathrm{~mm}$ (Grohs and others, 2009). Once pallid sturgeon in the Missouri River have transitioned to a fish-dominated diet, they feed on a variety of fish species such as Hybognathus minnows, channel catfish (Ictalurus punctatus) and blue catfish (Ictalurus furcatus), sicklefin chub, sturgeon chub, and johnny darter (Etheostoma nigrum) (Gerrity and others, 2006; Grohs and others, 2009). It has been hypothesized, however, that pallid sturgeon specialize on the native Missouri River chub species (Gerrity and others, 2006). Studies that link pallid sturgeon growth or condition with prey abundance in the Missouri River are absent. A strong correlation between prey fish catch (catch per unit effort, or CPUE) and pallid sturgeon condition may be used to infer that a cause and effect relationship exists; such correlation approaches have been used to identify the potential link between prey fish availability and fish condition for other species (Rätz and Lloret, 2003; VanDeValk and others, 2008). We hypothesize that a strong positive correlation between pallid sturgeon condition and catch rates of potential prey would support the inference that low prey availability may be associated with reduced pallid condition in the Missouri River. As was stated previously, correlation does not necessarily imply causation; however, a strong correlation can be used to identify research needs and additional hypotheses that further explore the potential cause and effect relationship.

To explore causative factor(s) for the increased proportion of "skinny" pallid sturgeon, we correlated the annual proportion of "skinny" pallid sturgeon compared to several hypothesized independent variables. These independent variables included intra- and interspecific competition within sturgeon species and availability of prey resources. Data were acquired from the long-term pallid sturgeon PSPAP (Welker and Drobish, 2016) sampling efforts for these comparisons and these analyses were restricted to the Lower Missouri River. For comparative analyses, the Lower Missouri River was subdivided at the confluence of the Kansas River (RM 367) because previous analysis has shown a difference in pallid sturgeon condition (Steffensen and others, 2016); relative abundance of shovelnose sturgeon (Steffensen, Stukel, and others, 2014); and relative abundance of Macrhybopsis, Hybognathus and cyprinid species (Steffensen, Shuman, and others, 2014; Huenemann and others, 2015) upstream and downstream from the confluence. Shovelnose sturgeon relative abundance, indexed by gillnets, generally represents the abundance of large shovelnose sturgeon because most (that is, 85 percent) shovelnose sturgeon captured in PSPAP gillnets were at least $500 \mathrm{~mm}$. Partitioning shovelnose sturgeon CPUE into length groups was not justified by diet studies of the species, which do not indicate ontogenetic diet shift in shovelnose sturgeon (Modde and Schmulbach, 1977; Gerrity and others, 2006; Wanner and others, 2007; Rapp and others, 2011). 
The recent invasion of Asian carps (mostly bighead and silver carp) is worthy of special note. No Federal or State agency in the Lower Missouri River presently (2017) has a systematic monitoring program for Asian carps. Because of their specific habitat usage and abilities to evade nets, special sampling protocols are necessary for Asian carp. Existing monitoring programs, like the PSPAP, catch some Asian carp as bycatch, but the sampling protocols used in the PSPAP are considered ineffective for these elusive species. As a result, there are no robust datasets sufficient for documenting relative abundance or trends in Asian carp in the Lower Missouri River. Nonetheless, accounts by fisheries professionals and the public leave no doubt that Asian carps have invaded throughout the Lower Missouri River and presently constitute a substantial portion of the fish community. Lacking quantitative records, however, the assessment of potential Asian carp effects on pallid sturgeon populations must focus on indirect evaluations. As pelagic planktivores, Asian carps are not expected to compete directly with benthic invertivorous/piscivorous pallid sturgeon; therefore, documenting competition would require tracing food-web interactions through multiple trophic levels. We discuss the potential for assessment of Asian carp competition in the "Discussion-Future Directions in Assessing Pallid Sturgeon Condition" section.

Further hypothesized factors that could likely affect pallid sturgeon condition could not be assessed due to lack of robust datasets. For example, flathead catfish (Pylodictis olivaris) and blue catfish (Ictalurus furcatus) are high trophic-level predators that may directly compete against pallid sturgeon for food resources, but PSPAP lacks a long-term, standardized electrofishing dataset to investigate this potential relationship. Anecdotal observations indicate that blue catfish are expanding their range upriver because anglers are reporting a higher frequency of "big” blue catfish being caught (K. Steffensen, Nebraska Game and Parks Commission, unpub. data, July 2017) and catch rates for age-0 blue catfish are increasing in the Gavins Point Dam to Kansas River reach of the Missouri River.

\section{Evaluation with Available Data}

Relative abundances (CPUE) of pallid and shovelnose sturgeon were calculated for standardized gillnet sampling to assess the potential effects of competition on pallid sturgeon condition. The gillnet was selected as the best gear to monitor the sturgeon populations because it has been utilized since the inception of the PSPAP, providing uniform data from 2003 to 2015. Gillnet CPUE was calculated as fish per 100 feet ( $\mathrm{ft}$ ) and was summarized for each section (upstream and downstream from the Kansas River) and sample year as the mean of all subsamples within a reach. The data were limited to random subsamples within the randomly selected bends within the sampling regime of the PSPAP. Pallid sturgeon CPUE was calculated for three length categories and an overall CPUE. Pallid sturgeon were classified into three length categories to evaluate intraspecific competition hypotheses related to reproductive status and ontogenetic diet shifts: $<600 \mathrm{~mm}$ FL (juvenile, non-piscivorous), 600-799 mm (subadult, piscivorous), and $>799 \mathrm{~mm}$ (adult, piscivorous).

A potential hypothesis asserts that increases in the relative abundance of large shovelnose sturgeon, and subsequently competition with pallid sturgeon, follows reduced exploitation after implementation of the 2010 FWS Similarity of Appearance (SOA) ruling, under which commercial fishing for shovelnose sturgeon was banned in waters where both species were colocated. Information relevant to that hypothesis is incorporated into this analysis indirectly by assessing the correlation of shovelnose sturgeon CPUE with the proportion of "skinny" pallid sturgeon. Overall, shovelnose sturgeon CPUE likely adequately represented changes in 
shovelnose sturgeon abundance due to the SOA because PSPAP gillnets primarily capture larger shovelnose sturgeon (for example, 85 percent of shovelnose sturgeon captured in PSPAP gillnets were $500 \mathrm{~mm}$ or greater) and commercial fishing typically targets larger shovelnose sturgeon (for example, $>578 \mathrm{~mm}$; Bettoli and others (2009)).

Prey availability was quantified as the relative abundance (CPUE) of potential fish prey species $<150 \mathrm{~mm}$. Otter trawl CPUE (fish per $100 \mathrm{~m}$ trawled) was used to index blue catfish, channel catfish, flathead catfish (Pylodictis olivaris), total catfish (previously mentioned species and unidentified), sicklefin chub, sturgeon chub, shoal chub (Macrhybopsis hyostoma), silver chub (Macrhybopsis storeriana), and total Macrhybopsis chubs. Mini-fyke net CPUE (fish per net-night) was used to index relative abundance of total Hybognathus (including brassy minnow, Hybognathus hankinsoni, plains minnow, Hybognathus placitus, Mississippi silvery minnow, Hybognathus nuchalis, and western silvery minnow, Hybognathus argyritis) and total target cyprinid species (including emerald shiner, Notropis atherinoides, red shiner, Cyprinella lutrensis, and sand shiner, Notropis stramineus). Gizzard shad (Dorosoma cepedianum) was assessed independently. For each gear, CPUE was summarized for each reach and sample year as the mean of all subsamples within a reach.

A size-specific proportion of "skinny" pallid sturgeon was determined by calculating the basin-wide mean ( \pm 1 standard deviation) relative condition using Alternative Kn equation (eq. 2). Pallid sturgeon were then classified as "skinny" if their individual condition was $>1$ standard deviation below the basin-wide mean. The annual proportion of "skinny" fish was then calculated within each segment as the dependent variable.

Dependent variables (that is, proportion of "skinny" pallid sturgeon) were correlated against the aforementioned independent variables. Because most pallid sturgeon are captured during spring sampling and independent variables are assessed during the summer and early fall months, we also adjusted the independent variables 1 year forward to account for a response time in pallid sturgeon condition. Assessing year-in and the 1-year offset allows assessment if pallid sturgeon are utilizing the existing (year-in) resources or if pallid sturgeon were able to take advantage of the reproduction and recruitment (1-year offset) that occurred during the summer months. Significance was determined at $\alpha=0.05$.

\section{Results of Competition Analysis}

The correlation between the proportion of "skinny" juvenile $(<600 \mathrm{~mm})$ pallid sturgeon and the relative abundance of juvenile pallid sturgeon and all sized shovelnose sturgeon in gill nets did not result in any positive significant relationship for the section from Gavins Point Dam to the confluence with the Kansas River (table 19); however, a negative correlation ( $\mathrm{r}=0.62$, $\mathrm{p}=0.0248$ ) with the proportion of "skinny" juvenile pallid sturgeon and a 1-year offset for the relative abundance of shovelnose sturgeon in gill nets did exist. Juvenile pallid sturgeon diet primarily consists of aquatic invertebrates, which is similar to shovelnose sturgeon (Wanner and others, 2007; Braaten and others, 2012); therefore, we hypothesized that if macroinvertebrate populations were limited there would be a positive density-dependent relationship between relative abundance of both sturgeon species and the observed decline in pallid sturgeon condition. Additionally, Gerrity and others (2006) identified a low niche overlap between juvenile pallid sturgeon and shovelnose sturgeon. No other comparisons were completed due to lack of annual macroinvertebrate abundance estimates and the different feeding behaviors (for example, ontogenetic diet shift) in pallid sturgeon. 
Table 19. Summary of the correlation statistics for hypothesized independent variables which maybe affecting juvenile $(<600 \mathrm{~mm})$ pallid sturgeon condition in the Lower Missouri River.

\begin{tabular}{|c|c|c|c|c|c|c|c|c|}
\hline \multirow[b]{3}{*}{ Variable } & \multicolumn{4}{|c|}{$\begin{array}{c}\text { Gavins Point Dam to the } \\
\text { Kansas River } \\
\text { (Segments 7, } 8 \text { \& 9) } \\
\end{array}$} & \multicolumn{4}{|c|}{$\begin{array}{l}\text { Kansas River to the } \\
\text { Mississippi River } \\
\text { (Segments 10, } 13 \text { \& 14) }\end{array}$} \\
\hline & \multicolumn{2}{|c|}{$\begin{array}{c}\begin{array}{c}\text { Annual } \\
\text { comparison }\end{array} \\
\end{array}$} & \multicolumn{2}{|c|}{ 1-year offset } & \multicolumn{2}{|c|}{$\begin{array}{c}\text { Annual } \\
\text { comparison }\end{array}$} & \multicolumn{2}{|c|}{ 1-year offset } \\
\hline & $r$ & $p$ & $r$ & $p$ & $r$ & $p$ & $r$ & $p$ \\
\hline & \multicolumn{8}{|c|}{ Gill net CPUE } \\
\hline $\begin{array}{l}\text { Juvenile } \\
\text { pallid } \\
\text { sturgeon }\end{array}$ & -0.29 & 0.3025 & -0.19 & 0.5338 & 0.6 & 0.0215 & 0.23 & 0.4332 \\
\hline $\begin{array}{c}\text { Shovelnose } \\
\text { sturgeon }\end{array}$ & -0.11 & 0.6904 & 0.46 & 0.1104 & -0.02 & 0.9332 & 0.02 & 0.9427 \\
\hline
\end{tabular}

The lower section of the Lower Missouri River did show a significant positive correlation between the proportion of "skinny" juvenile pallid sturgeon and juvenile pallid sturgeon CPUE $(r=0.57, p=0.0339)$. This positive correlation may be indicative of intraspecific completion, a condition that may warrant careful assessment by the augmentation program.

The piscivory transition for pallid sturgeon occurs at approximately $600 \mathrm{~mm}$ (Grohs and others, 2009) and minimum length of maturity occurs around $800 \mathrm{~mm}$ (Steffensen and others, 2013b); therefore, subadult-sized pallid sturgeon (600-800 mm) were assessed independently. The proportion of "skinny" subadult pallid sturgeon displayed a significant positive correlation $(r=0.66, p=0.018)$ with the relative abundance of adult-sized $(>800 \mathrm{~mm})$ pallid sturgeon; analysis with a 1 -year offset was also significant $(r=0.67, p=0.016$; table 20). As adult-sized pallid sturgeon catch rates increased after the 2011 flood in the section above the Kansas River, so did the proportion of "skinny" subadult-sized pallid. The increased catch rates in the adult-sized population in this section documents an apparent upstream immigration and residency into this area, potentially increasing competition with subadult pallid sturgeon for limited forage resources. Similarly, the section downstream from the Kansas River confluence showed a positive correlation between proportion of "skinny fish" and the relative abundance of adult sized pallid sturgeon $(r=0.67, p=0.011$; table 20$)$.

Winders and Steffensen (2014) determined that the Ictaluridae species were the most important prey in the Lower Missouri River for subadult and adult pallid sturgeon. Evidence of the importance of Ictalurid prey relationships is questionable because we determined a significant positive correlation $(r=0.74, p=0.005)$ in the relative abundance of blue catfish and proportion of "skinny" subadult pallid sturgeon, and in the 1 -year offset $(r=0.75, p=0.004)$. We suspect that if prey items are limited and affecting subadult-sized pallid sturgeon condition, then this relationship should be negative rather than positive. As the relative abundance of blue catfish increased so did the proportion of "skinny" subadult pallid sturgeon. These data would indicate that blue catfish are either not a primary dietary resource for pallid sturgeon or pallid sturgeon cannot take advantage of this resource. 
Table 20. Summary of the correlation statistics for hypothesized independent variables which may be affecting subadult $(600-800 \mathrm{~mm})$ pallid sturgeon condition in the Lower Missouri River.

\begin{tabular}{|c|c|c|c|c|c|c|c|c|}
\hline \multirow[b]{3}{*}{ Variable } & \multicolumn{4}{|c|}{$\begin{array}{l}\text { Gavins Point Dam to the } \\
\text { Kansas River } \\
\text { (Segments 7, } 8 \text { \& 9) }\end{array}$} & \multicolumn{4}{|c|}{$\begin{array}{l}\text { Kansas River to the } \\
\text { Mississippi River } \\
\text { (Segments 10, } 13 \text { \& 14) }\end{array}$} \\
\hline & \multicolumn{2}{|c|}{$\begin{array}{c}\text { Annual } \\
\text { comparison }\end{array}$} & \multicolumn{2}{|c|}{$\begin{array}{l}\text { 1-year } \\
\text { offset }\end{array}$} & \multicolumn{2}{|c|}{$\begin{array}{c}\text { Annual } \\
\text { comparison }\end{array}$} & \multicolumn{2}{|c|}{$\begin{array}{l}\text { 1-year } \\
\text { offset }\end{array}$} \\
\hline & $r$ & $p$ & $r$ & $p$ & $r$ & $p$ & $r$ & $p$ \\
\hline & \multicolumn{8}{|c|}{ Gill net CPUE } \\
\hline $\begin{array}{l}\text { Subadult } \\
\text { pallid } \\
\text { sturgeon }\end{array}$ & 0.18 & 0.573 & 0.25 & 0.431 & 0.18 & 0.526 & 0.15 & 0.606 \\
\hline \multirow[t]{2}{*}{$\begin{array}{l}\text { Adult pallid } \\
\text { sturgeon }\end{array}$} & 0.66 & 0.018 & 0.67 & 0.016 & 0.3 & 0.287 & 0.67 & 0.011 \\
\hline & \multicolumn{8}{|c|}{ Otter trawl CPUE } \\
\hline Overall & -0.1 & 0.667 & -0.3 & 0.266 & 0.03 & 0.908 & 0.09 & 0.768 \\
\hline Sicklefin chub & -0.1 & 0.778 & -0.1 & 0.66 & 0.12 & 0.66 & 0.19 & 0.514 \\
\hline Sturgeon chub & -0.4 & 0.151 & -0.2 & 0.52 & 0.18 & 0.538 & 0.6 & 0.029 \\
\hline Shoal chub & 0.4 & 0.19 & -0.1 & 0.747 & 0.1 & 0.72 & 0.35 & 0.238 \\
\hline Silver chub & -0.2 & 0.515 & -0.3 & 0.311 & 0.18 & 0.528 & 0.2 & 0.504 \\
\hline $\begin{array}{l}\text { Macrhybopsis } \\
\text { species }\end{array}$ & -0.1 & 0.685 & -0.3 & 0.351 & 0.08 & 0.784 & 0.27 & 0.372 \\
\hline Blue catfish & 0.74 & 0.005 & 0.75 & 0.004 & -0.1 & 0.784 & -0.1 & 0.745 \\
\hline $\begin{array}{l}\text { Channel } \\
\text { catfish }\end{array}$ & -0.4 & 0.211 & -0.5 & 0.134 & -0.1 & 0.821 & 0.01 & 0.982 \\
\hline $\begin{array}{l}\text { Flathead } \\
\text { catfish }\end{array}$ & -0.1 & 0.856 & -0.1 & 0.722 & 0.25 & 0.382 & -0.3 & 0.322 \\
\hline \multirow[t]{2}{*}{ All catfish } & 0.16 & 0.599 & -0.3 & 0.426 & -0.1 & 0.864 & -0 & 0.903 \\
\hline & \multicolumn{8}{|c|}{ Mini-fyke net CPUE } \\
\hline $\begin{array}{l}\text { Hybognathus } \\
\text { species }\end{array}$ & 0.31 & 0.316 & -0 & 0.926 & -0.2 & 0.525 & 0.05 & 0.87 \\
\hline $\begin{array}{l}\text { Cyprinid } \\
\text { species }\end{array}$ & -0.1 & 0.82 & 0.02 & 0.936 & -0.3 & 0.295 & -0.3 & 0.348 \\
\hline Gizzard shad & -0.2 & 0.467 & -0.3 & 0.37 & 0.01 & 0.993 & 0.33 & 0.267 \\
\hline
\end{tabular}

Finally, we were unable to detect any significant relationship between the proportion of "skinny" adult-sized $(>800 \mathrm{~mm})$ pallid sturgeon and any variables representing competition or prey availability in either section of the Lower Missouri River (table 21). We conclude that the correlation analysis of pallid sturgeon condition and existing records of potential competitors and prey provides ambiguous information. Correlation of adult pallid sturgeon CPUE and "skinny" subadult pallid sturgeon may indicate intraspecific competition in some places, but more detailed assessments are necessary. 
Table 21. Summary of the correlation statistics for hypothesized independent variables which may be affecting adult (> $800 \mathrm{~mm}$ ) pallid sturgeon condition in the Lower Missouri River.

\begin{tabular}{|c|c|c|c|c|c|c|c|c|}
\hline \multirow[b]{3}{*}{ Variable } & \multicolumn{4}{|c|}{$\begin{array}{c}\text { Gavins Point Dam to the } \\
\text { Kansas River } \\
\text { (Segments 7, } 8 \text { \& 9) }\end{array}$} & \multicolumn{4}{|c|}{$\begin{array}{l}\text { Kansas River to the } \\
\text { Mississippi River } \\
\text { (Segments 10, } 13 \text { \& 14) }\end{array}$} \\
\hline & \multicolumn{2}{|c|}{$\begin{array}{c}\text { Annual } \\
\text { comparison }\end{array}$} & \multicolumn{2}{|c|}{ 1-year offset } & \multicolumn{2}{|c|}{$\begin{array}{c}\text { Annual } \\
\text { comparison }\end{array}$} & \multicolumn{2}{|c|}{ 1-year offse } \\
\hline & $r$ & $p$ & $r$ & $p$ & $r$ & $p$ & $r$ & $p$ \\
\hline \multicolumn{9}{|c|}{ Gill net CPUE } \\
\hline $\begin{array}{l}\text { Subadult pallid } \\
\text { sturgeon }\end{array}$ & -0.33 & 0.2413 & -0.14 & 0.641 & 0.02 & 0.9365 & 0.4 & 0.1736 \\
\hline $\begin{array}{l}\text { Adult pallid } \\
\text { sturgeon }\end{array}$ & -0.17 & 0.5535 & 0.5 & 0.0765 & 0.16 & 0.5772 & 0.51 & 0.0693 \\
\hline \multicolumn{9}{|c|}{ Otter trawl CPUE } \\
\hline Overall & 0.02 & 0.9233 & 0.18 & 0.5391 & -0.24 & 0.4056 & 0.14 & 0.6397 \\
\hline Sicklefin chub & 0.17 & 0.5607 & -0.02 & 0.9462 & 0.11 & 0.7028 & 0.17 & 0.5628 \\
\hline Sturgeon chub & 0.03 & 0.9065 & -0.25 & 0.3933 & 0.23 & 0.4199 & 0.45 & 0.1169 \\
\hline Shoal chub & 0.33 & 0.239 & 0.47 & 0.1011 & 0.12 & 0.6705 & 0.37 & 0.203 \\
\hline Silver chub & -0.17 & 0.56 & -0.03 & 0.899 & 0.06 & 0.8127 & 0.3 & 0.31 \\
\hline $\begin{array}{l}\text { Macrhybopsis } \\
\text { species }\end{array}$ & 0.01 & 0.9967 & 0.12 & 0.6788 & 0.07 & 0.7945 & 0.28 & 0.3445 \\
\hline Blue catfish & -0.07 & 0.8058 & 0.42 & 0.1519 & -0.29 & 0.301 & -0.18 & 0.5552 \\
\hline Channel catfish & 0.19 & 0.5074 & 0.22 & 0.4604 & -0.25 & 0.3773 & -0.09 & 0.7528 \\
\hline Flathead catfish & -0.4 & 0.147 & -0.11 & 0.7085 & -0.37 & 0.1887 & -0.12 & 0.6831 \\
\hline All catfish & 0.17 & 0.5444 & 0.37 & 0.2122 & -0.33 & 0.2466 & -0.14 & 0.645 \\
\hline \multicolumn{9}{|c|}{ Mini-fyke net CPUE } \\
\hline $\begin{array}{l}\text { Hybognathus } \\
\text { species }\end{array}$ & 0.18 & 0.5273 & 0.3 & 0.3119 & 0.03 & 0.9139 & -0.12 & 0.685 \\
\hline Cyprinid species & -0.43 & 0.1221 & 0.07 & 0.8199 & -0.18 & 0.5163 & -0.22 & 0.4694 \\
\hline Gizzard shad & -0.14 & 0.621 & -0.12 & 0.6834 & 0.03 & 0.9071 & 0.26 & 0.3844 \\
\hline
\end{tabular}

\section{Hypothesis-Long- and Short-Term Trends in River Morphology Have Diminished Habitat for Pallid Sturgeon or Prey Species}

Because river morphology sets the template of physical habitat for all aquatic species, this hypothesis interacts with many others, including inter- and intraspecific competition and general carrying capacity of the river. Chronic, long-term trends are related to the post-dam, post-channelization history of the Missouri River. These physical changes to the Missouri River system since the 1950s have been well documented although there has not been a robust translation of those changes into habitat values for invertebrates, prey fish, or pallid sturgeon. Channelization, land accretion, and construction of channel-training structures decreased channel complexity and top-width of the river by 50-65 percent (Funk and Robinson, 1974; Hallberg and others, 1979; Hesse and Sheets, 1993; Jacobson and Galat, 2006). Changes to the flow regime include substantially decreased peak flows in spring and increased summer and fall flows to support navigation (Galat and Lipkin, 2000; Pegg and others, 2003). At the same time, 
deposition of sediment in reservoirs decreased turbidity (Blevins, 2006) and the suspended sediment load of the river decreased to essentially zero just downstream from Gavins Point Dam and to 17 percent of the historical annual load at St. Charles, Mo. (Jacobson and others, 2009).

Hypotheses linking pallid sturgeon condition to habitat changes can be divided into hypotheses that focus on foraging bioenergetics for pallid sturgeon and those that focus on habitats that support pallid sturgeon prey items, including invertebrates and prey fish. Although some habitat affinities for adult pallid sturgeon have been documented, much more remains to be learned about habitat requirements for juveniles and food items. The hypothesis that foraging habitat for adult pallid sturgeon may have diminished over time is based on the idea that flow regime and channel adjustments may have resulted in less bioenergetically favorable conditions. Such conditions may be habitat changes that have decreased prey density (requiring more swimming to forage for equivalent calories), increased current velocities, or decreased flow refugia. Specific foraging habitat conditions have not been well documented for adult pallid sturgeon, although data indicate selection for sand bottom (Bramblett and White, 2001) and depths and velocities somewhat lower than average in the channelized Lower Missouri River (DeLonay and others, 2009). Migrating reproductive pallid sturgeon select energetically optimal pathways by exploiting lower velocities on inside bends and by using hydraulic refugia in sanddune fields (McElroy and others, 2012), and presumably foraging strategies are similar.

Long-term channel-morphology changes have been documented at Missouri River streamflow-gaging station locations (fig. 1). Although streamflow-gaging station locations are selected for their stable channel form, usually associated with bridges in urban areas, and may therefore not be representative of much of the river channel, they constitute a unique dataset for indicating long-term geomorphic changes. In specific-gage analysis (fig. 19), discharge rating measurement data are compiled on an approximately yearly basis to document water-surface elevations associated with specific discharges or discharge exceedances. Missouri River streamflow-gaging stations generally show decreasing water-surface elevations for highexceedance (low flow) discharges over time and increasing water-surface elevations for lowexceedance (high flow) discharges (for example, fig. 19B). The interpretation of these trends is that a combination of channelization and diminished sediment supply has resulted in channel incision in the thalweg or navigation channel. Increases in water-surface elevation have been variably attributed to decreased channel conveyance as a result of effects of channel training structures; constriction by bridges, levees, or floodwalls; and ongoing sedimentation on channel margins and in overbank areas (Pinter and Heine, 2005; Pinter, 2010). Some streamgages document increases in water-surface elevations at intermediate exceedances, which may result from aggradation of the thalweg (fig. 19B-D). The so-called "low-conveyance" zone extends from midway between Sioux City, Iowa, and Omaha, Nebr., to at least St. Joseph, Mo. From downstream from St. Joseph through the Kansas City reach, the river channel incises even more, whereas overbank stages have continued to increase through time as a result of decreased conveyance of low-exceedance flows. Downstream from Kansas City to St. Louis, Mo., channel incision has been of lower intensity and less consistent, whereas amplification of stages of higher flows continues. Importantly, trends at high and low exceedance have been consistent since the 1950s, indicating ongoing adjustment of the channel. Longitudinal changes in water-surface elevation at a relatively high exceedance have also been documented by resurveys of the construction reference plane (CRP), an imaginary surface at 75-percent flow exceedance. The longitudinal distribution of changes in the CRP aptly illustrates how channel adjustment varies along the Lower Missouri River (fig. 20). 

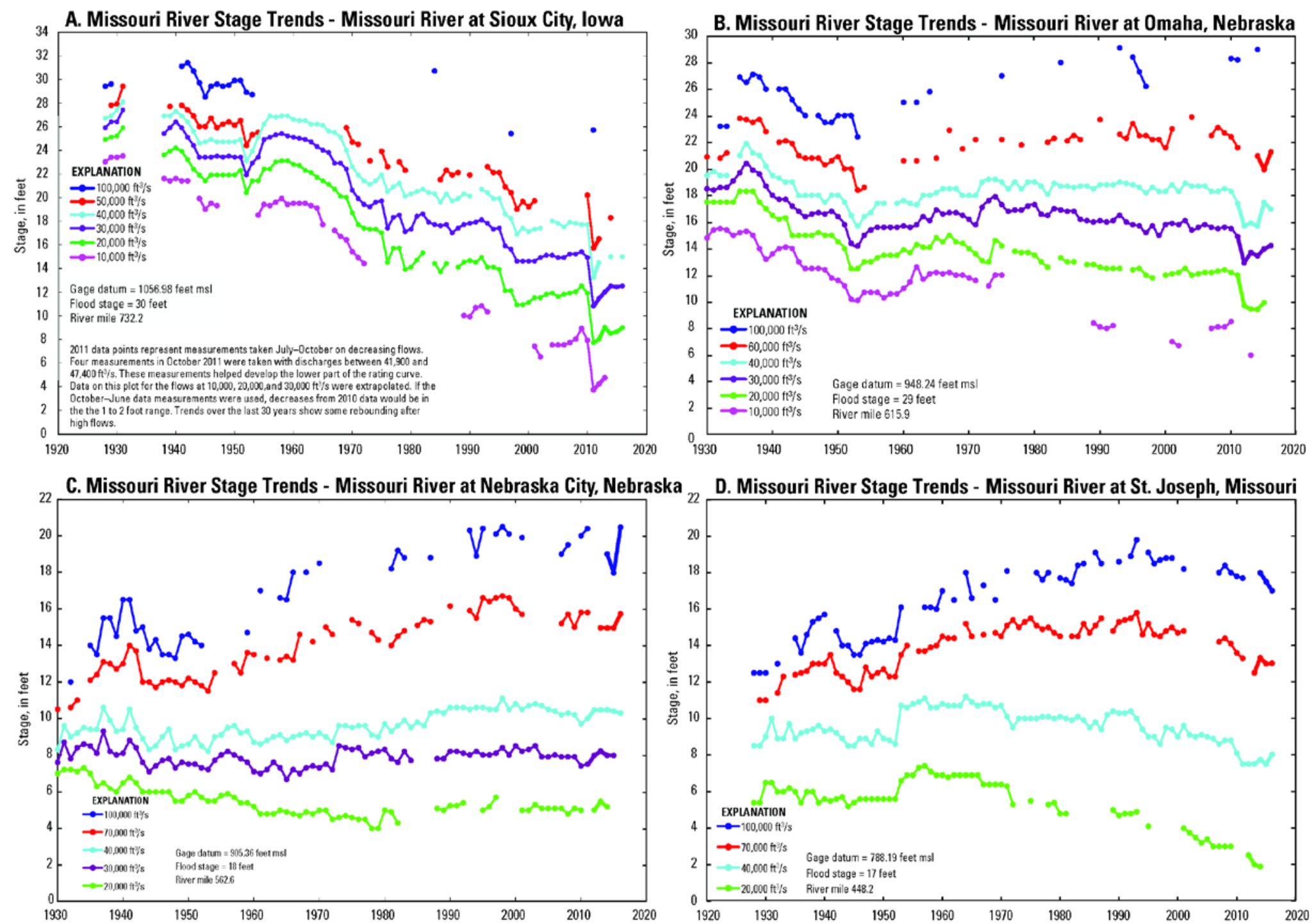

Figure 19. Graphs of water-surface elevation over time for selected discharges, selected streamgages, Missouri River. Modified and updated from U.S. Army Corps of Engineers (2012). A, Missouri River at Sioux City, lowa; B, Missouri River at Omaha, Nebraska; C, Missouri River at Nebraska City, Nebraska; $D$, Missouri River at St. Joseph, Missouri. 

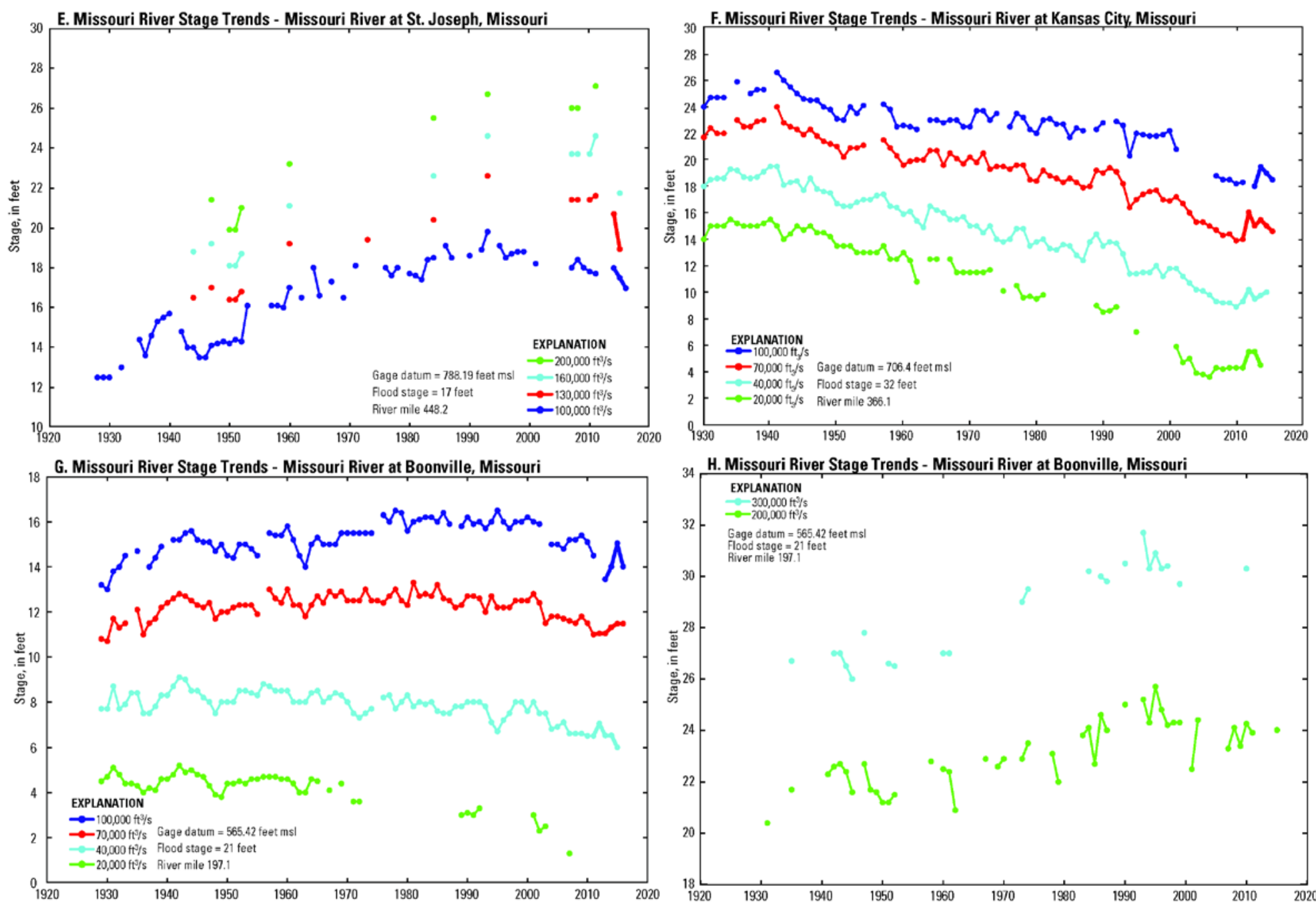

Figure 19 (Continued). Graphs of water-surface elevation over time for selected discharges, selected streamgages, Missouri River. Modified and updated from U.S. Army Corps of Engineers (2012). E, St. Joseph, Missouri; F, Kansas City, Missouri; G, Boonville, Missouri; $H$, Boonville, Missouri. 


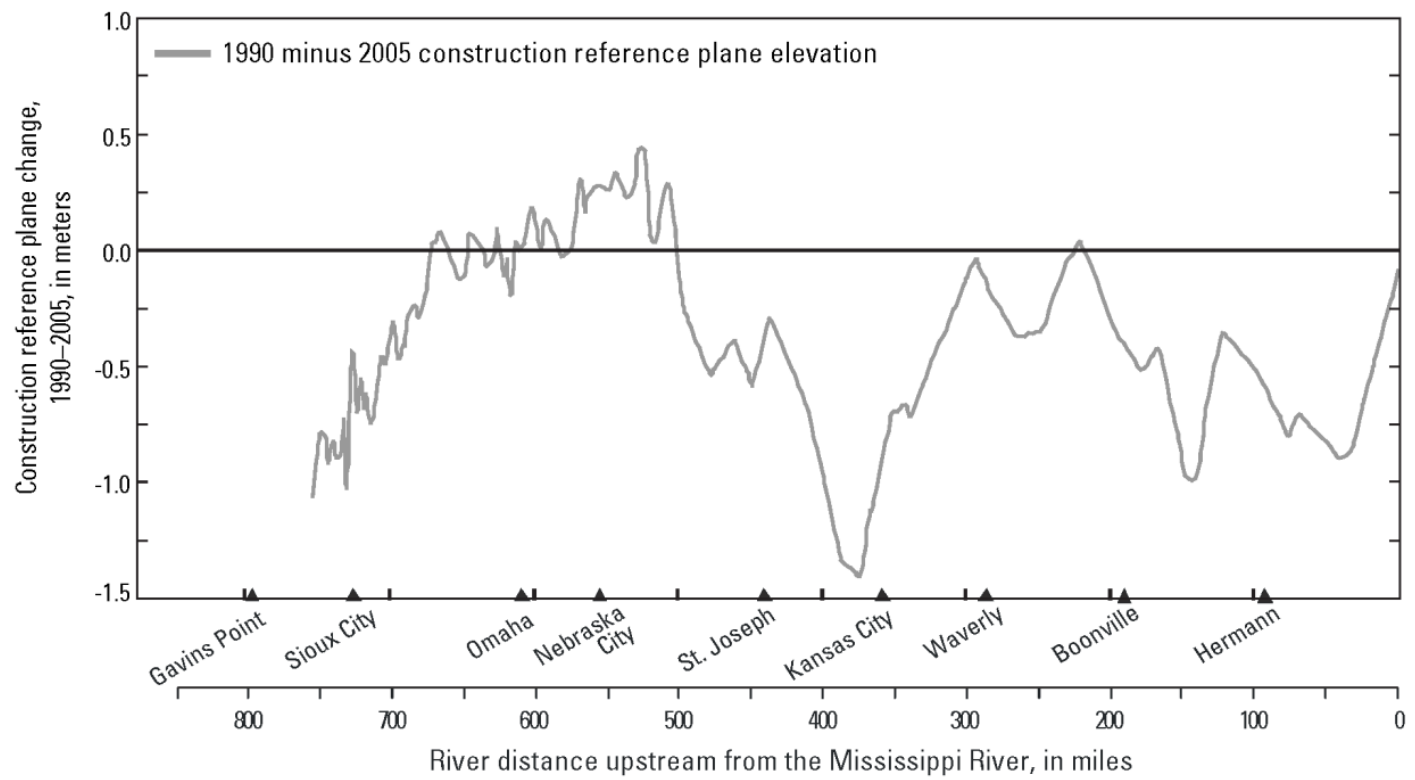

Figure 20. Changes in the construction reference plane, Sioux City, lowa, to the confluence with the Mississippi River. From Jacobson and others (2009).

\section{Evaluation with Available Data}

Interpretation of habitat trends from specific-gage analysis is challenging because of potential lack of representativeness of the gage locations and the difficulty of translating morphological change to habitat change. Nonetheless, one may infer that channel incision accompanying decreasing high-exceedance water-surface elevations indicates consolidation of flow into a narrow navigation channel and potential disconnection of the thalweg from channelmarginal habitats, off-channel waterbodies, and the flood plain. Increasing water-surface elevations for low-exceedance discharges may indicate progressive sedimentation in overbank areas and between wing dikes, which is reflective of diminished channel complexity and decreased connectivity with flood plains. Together, this simplification of the channel may be hypothesized to be responsible for decreasing habitats that were formerly supportive of invertebrate and fish prey.

Additionally, rapid changes in pallid sturgeon condition since 2011 as documented in this report have prompted speculation that recent events have altered habitat availability or quality. Recent changes include post-2007 habitat restoration activities and extreme hydroclimatic events (floods of 2010 and 2011 and drought of 2012). Short-term trends in habitat may be indicative of a transient disturbance and recovery, or they could be indicative of achievement of a threshold of rapid change from which recovery is unlikely. The recent history documented in specific-gage analysis shows sharp incision of about $4 \mathrm{ft}$ for low flows at Sioux City in 2011 (fig. 19A), followed by recovery of about $1 \mathrm{ft}$. At Omaha, 2011 incision was about $3 \mathrm{ft}$, with variable recovery of 1-2 ft (fig. 19B). Incision related to the 2011 flood was not apparent from low-flow water-surface changes at Nebraska City or St. Joseph where multidecadal trends continued (fig. $19 C, D$ ). It is of interest that water-surface elevations for discharges of 100,000-160,000 cubic feet per second $\left(\mathrm{ft}^{3} / \mathrm{s}\right)$ at St. Joseph decreased 2-3 ft after the $2011 \mathrm{flood}$ (fig. 19E). Specific gage response to the 2011 flood at Kansas City was an apparent transient phenomenon, indicative of aggradation of the bed, followed by recovery to pre-existing trends (fig. 19F). At Boonville, 
Mo., low-flow water-surface elevations did not show appreciable effect of the 2011 flood (fig. $19 G, H)$.

The specific-gage analysis can be complemented by calculation of mean streambed elevation at each gage, which is a calculation that can be made each time a discharge measurement is taken, resulting in more frequent updates (fig. 21). The record of mean streambed elevation from 1990 to 2016 shows continued channel incision at gages from Sioux City, Iowa, to Boonville, Mo., with the exception of Nebraska City, Nebr. An episode of incision of about $3 \mathrm{ft}$ is evident coincident with the 2011 flood at Sioux City but the bed rebounded $3 \mathrm{ft}$ by late 2014, followed by another episode of incision to 2016 (fig. 21A). The streambed at Decatur, Nebr., incised about $2 \mathrm{ft}$ coincident with the 2011 flood, rebounded by $3 \mathrm{ft}$ by 2012, and then continued a modest rate of incision to 2016 (fig. 21B). At Omaha, Nebr., the 2011 flood was coincident with $5 \mathrm{ft}$ of incision, followed by a rebound of $3 \mathrm{ft}$ to 2016 (fig. 21C). At Nebraska City, Nebraska, the bed has been at a relatively stable elevation since 1990 and showed no apparent effect of the 2011 flood (fig. 21D). In contrast to upstream incision, the mean streambed elevation at Kansas City was increasing from 2007 to 2011, followed by a steady incision after 2011; an effect of the 2011 flood is not clearly indicated in the record (fig. 21E). At Boonville, Mo., mean streambed elevation showed no apparent effect of the 2011 flood, instead continuing a decadal-scale pattern of incision (fig. $21 F$ ). Recovery of the channel and resumption of the decadal pattern of incision or stability at most gages indicate that the 2011 flood effect was transient for bed elevations. These data support the hypothesis that short-term changes in channel physical condition may have affected fish condition, but additional work is needed to demonstrate that the channel responses were universal and that habitat and fishpopulation responses followed.

The hypothesis that channel changes are associated with increasing bioenergetic costs is supported in part by a record of slightly increasing velocities at some gages and decreasing variance in velocity as channelization proceeded from the late 1920 s to the 1980 s (fig. 22). The most recent changes in streambed elevation at these gages supports the hypothesis that shortterm incision of the channel in the Sioux City-Omaha segment may have increased channel simplification and velocities, further increasing bioenergetic costs. Recovery of the bed at these gages indicates that the effect may be transient.

A complementary perspective to temporal analysis of changes in habitat at limited locations is to evaluate spatial variation, especially with respect to the spatial variation in Kn documented for pallid sturgeon above (figs. 7, 8; tables 7, 8) and in Steffensen and others, (2016). Diminished Kn in segments 8 and 9 compared to other Missouri River segments is consistent with hydraulic variables compiled from USGS Comprehensive Sturgeon Research Project databases (fig. 23). Depth and velocity distributions for flows in the 25-75 percent exceedance range show progressive increases in velocity from upstream to downstream (with the exception of the Lower Yellowstone River, which is relatively steep and fast). Perhaps more importantly, the variance in velocity increases downstream from segments 8 and 9 with development of a bimodal velocity distribution. 

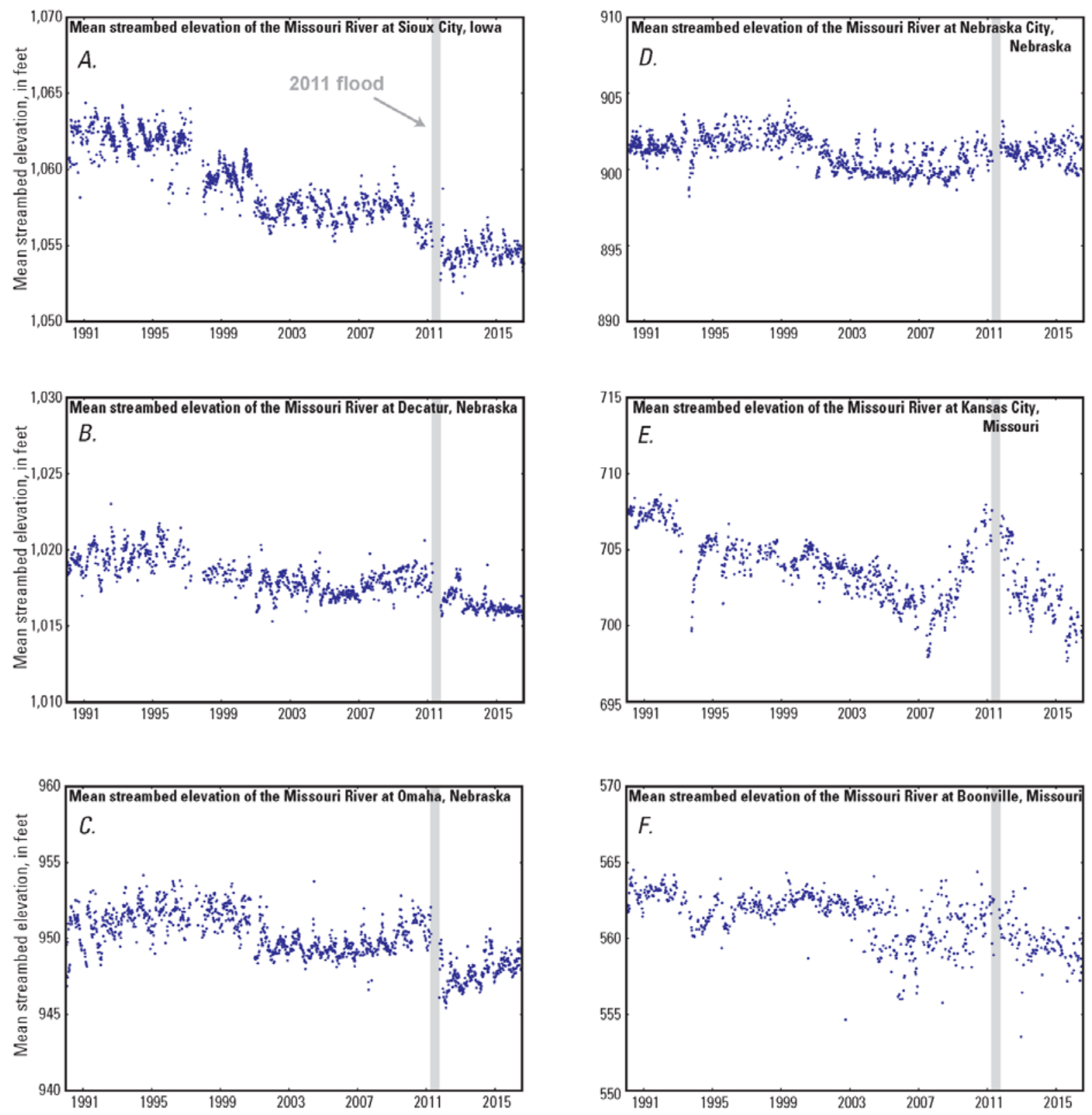

Figure 21. Mean streambed elevation plots for selected streamgages, Missouri River, 1990-2016. Data availability: U.S. Geological Survey (2016). 

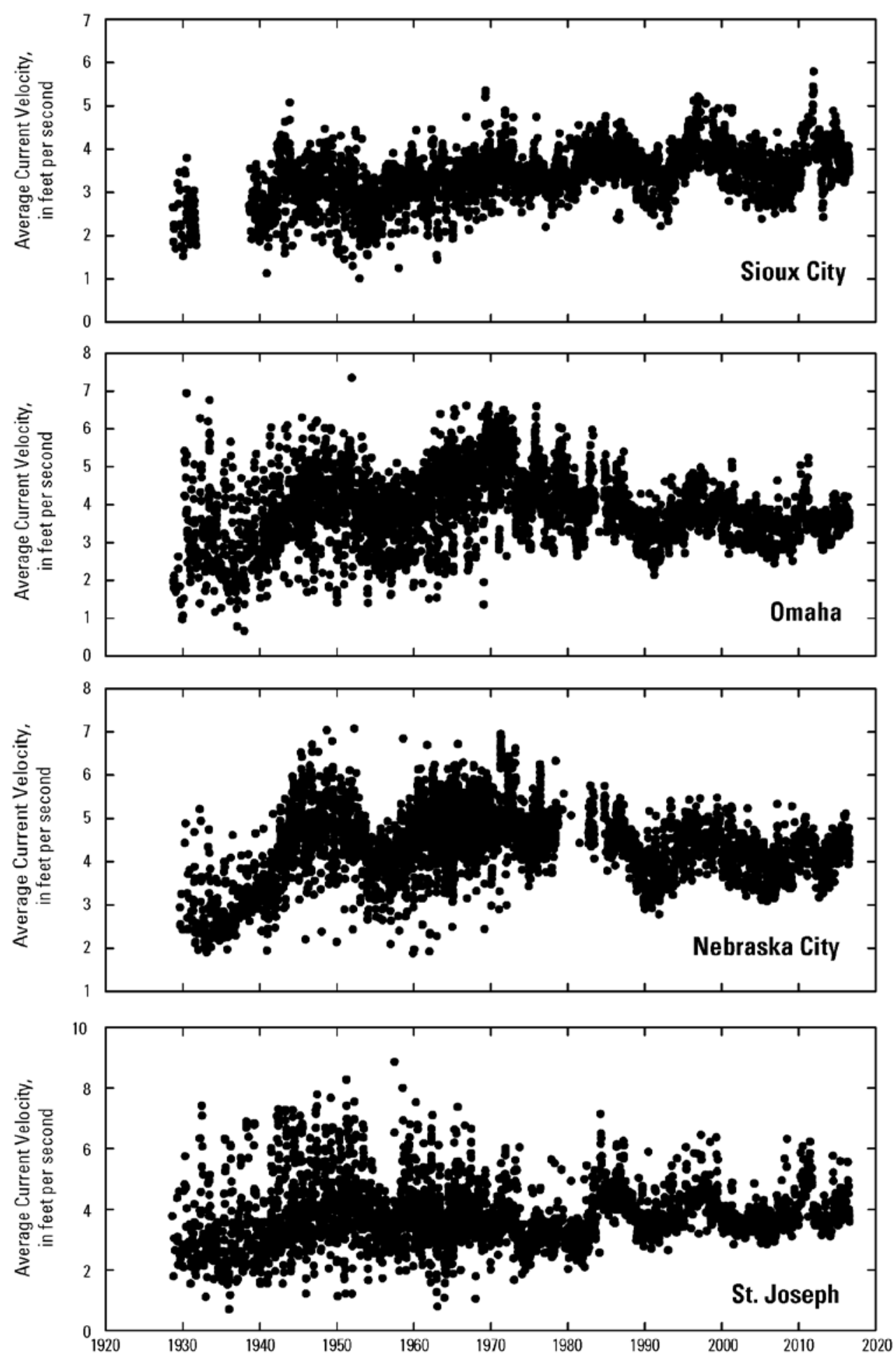

Figure 22. Velocity histories for selected streamgages, Missouri River 1928-2016. Data availability: U.S. Geological Survey (2016). 
The slow velocities are associated with channel margins and wing-dike fields in segments 10,13 , and 14 . These features may provide bioenergetically favorable flow refugia for subadult and adult pallid sturgeon. The channel is narrower and lacks these features in segments 8 and 9 where fish condition is lowest. Similarly, available depths and variance in depth increase in the downstream direction, indicating additional habitat complexity.

Another view of velocity variation can be gleaned from USGS streamflow-gaging stations, albeit with the caveats that such stations are not necessarily representative of the river between the gages and the mean channel velocities at gaging stations are only indicative of available velocities and do not document velocities actually used by pallid sturgeon (fig. 24). From the streamflow-gaging station data, current velocities can be calculated for similar flow exceedances, thereby normalizing for how much of the time these velocities are present in the channel. The velocities for the Upper Missouri River (Culbertson, Mont.) are substantially slower than the others for the range of flow exceedances. Velocity distributions for the Lower Missouri River at Sioux City, Iowa (segment 8) and Boonville, Mo., (segment 14) are very similar to each other and both are substantially lower than the velocities for the Lower Missouri River at Nebraska City, Nebr. (segment 9). Data for the Middle Mississippi River at Chester, Illinois, are presented for comparison because Steffensen and others (2016) documented that pallid sturgeon Kn was highest in the Middle Mississippi River compared to all Missouri River segments. The shape of the distribution is much steeper compared to the others, indicating that at low flows (high exceedances) velocities are similar to the Lower Missouri River, but at exceedance $<50$ percent the velocities climb and are substantially higher than those on the Missouri River. These data confirm that segment 9 may present bioenergetically challenging velocities for pallid sturgeon compared to other river reaches; ongoing morphologic changes at gages indicate that this could be a persistent and worsening condition. The velocity distribution on the Middle Mississippi River indicates that velocities encountered by pallid sturgeon will vary substantially with discharge, suggesting that existence of flow refugia may be important to maintain growth and condition.

The short-term hypothesis for foraging habitats is identical to the long-term hypothesis except that focus is on the last 10 years and whether there is any evidence for recovery from a transient disturbance. With the caveat that adult foraging habitat selection is not well defined, recent specific gage and mean streambed elevation trends indicate that post-2011 flood incision upstream from St. Joseph may have simplified the channel and further disconnected mainchannel habitats from channel-marginal habitats; however, reduction in connectivity between these habitat types can only be hypothesized based on these indirect measures. Moreover, it is also unknown whether altered habitats would be linked to declining pallid sturgeon condition. 

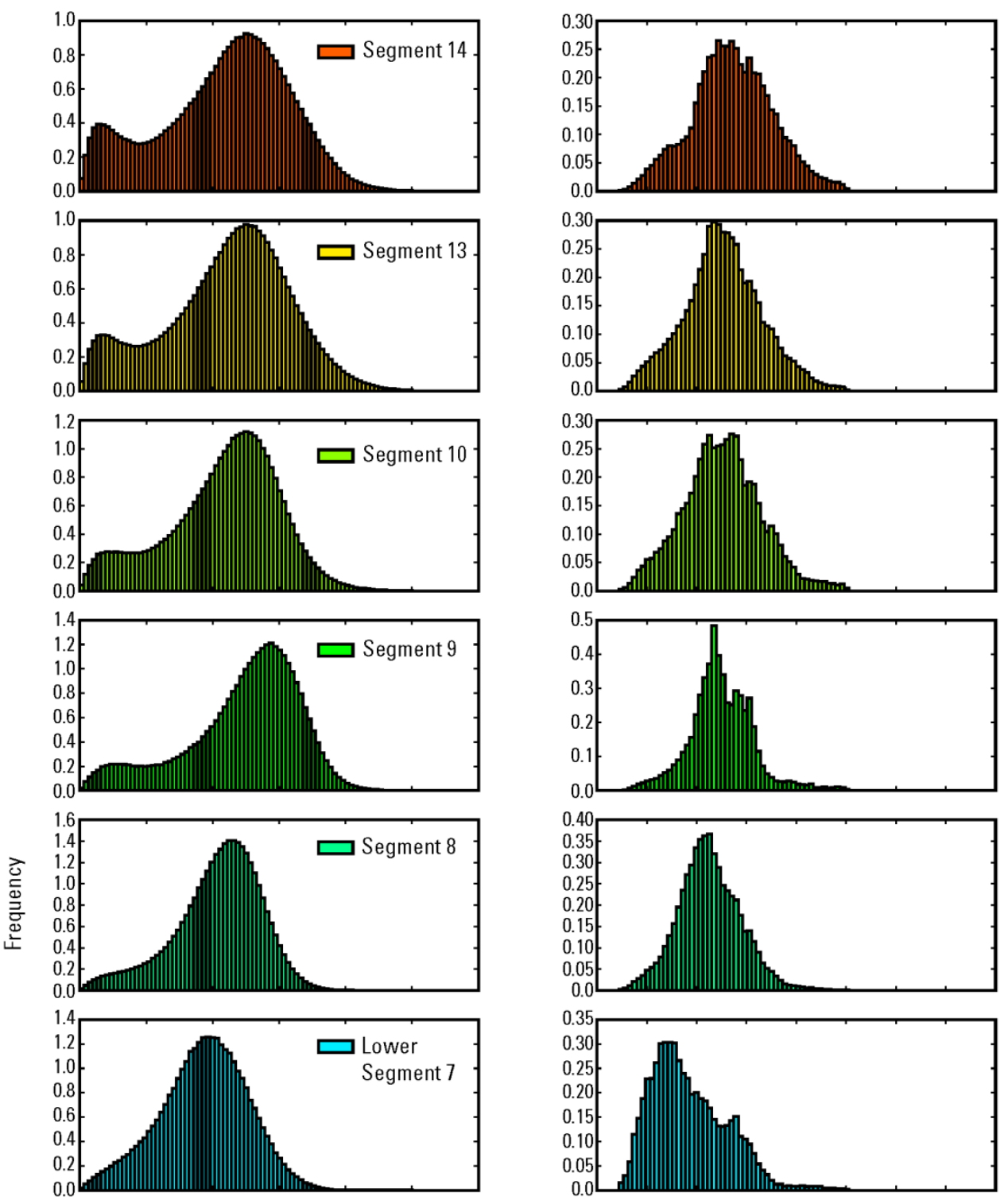

Figure 23. Histograms of depth and velocity by segment of the Yellowstone, Upper Missouri, and Lower Missouri River. Data availability: Bulliner and others (2017)
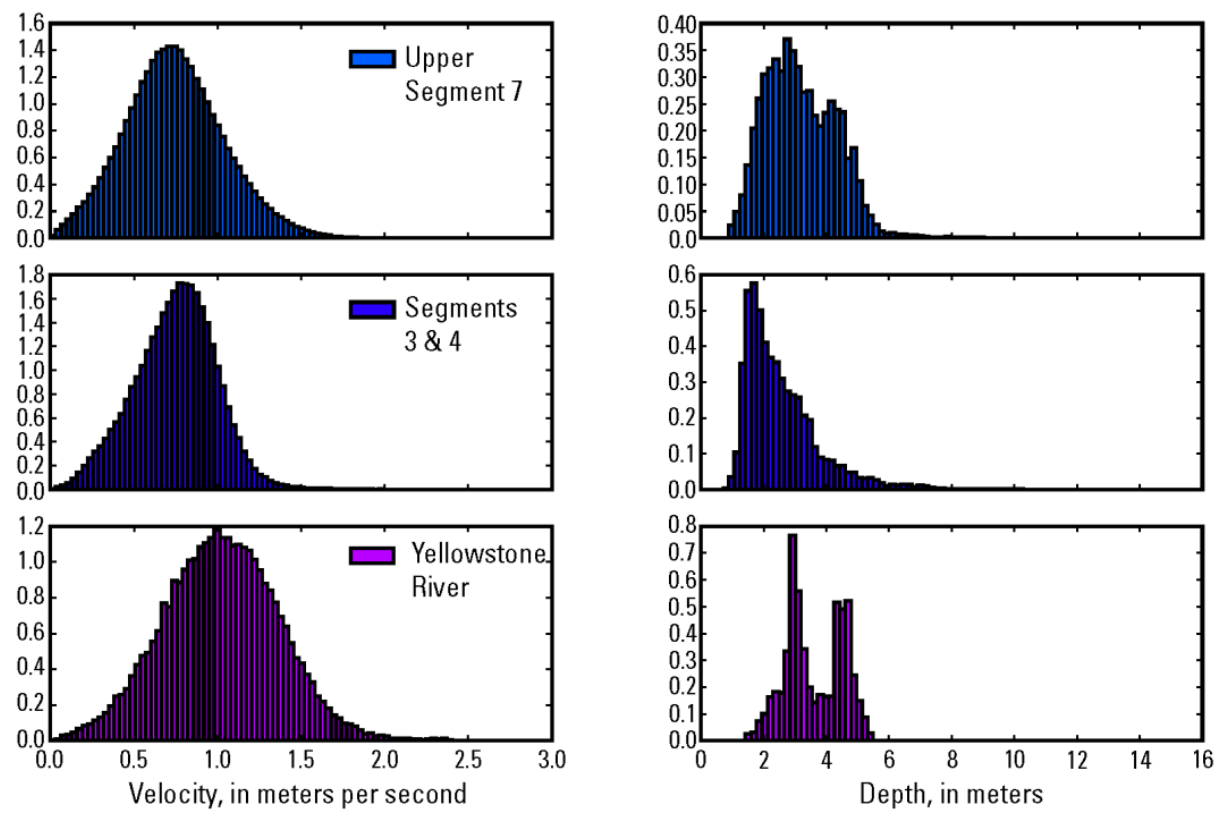


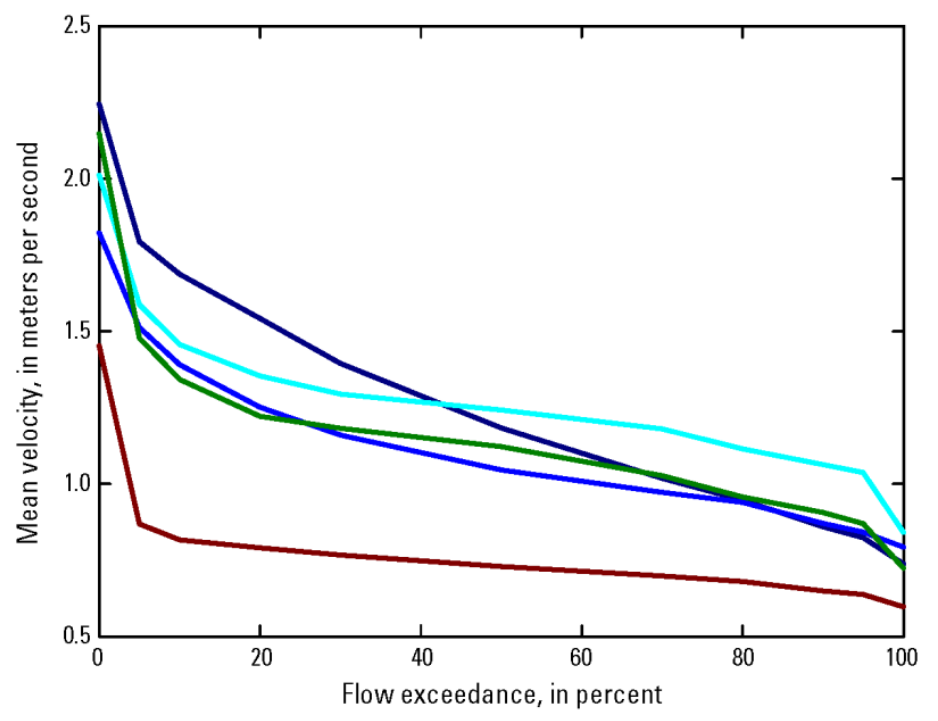

EXPLANATION

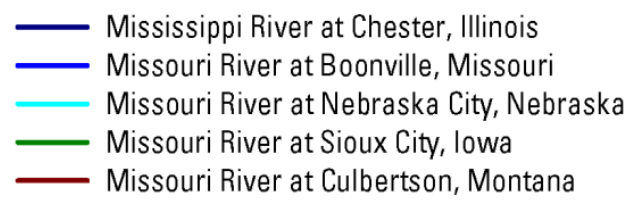

Figure 24. Relation between flow exceedance and mean velocity at selected streamflow-gaging stations. Data availability: U.S. Geological Survey (2016).

\section{Summary of Evidence for Causal Hypotheses}

To address question 2 , the team grouped potential causal hypotheses for declining pallid sturgeon condition into three categories relating to fish health, competition, and habitat limitations. Based on available information, we conclude that none of the hypotheses have compelling support. It is also important to note that multiple processes may be combining to result in declining condition and different processes may contribute to similar condition trends in different places along the river. The next section discusses future science directions that can be implemented to improve evaluation of these hypotheses.

\section{Discussion-Future Directions in Assessing Pallid Sturgeon Condition}

Additional investigation is required to understand declining pallid sturgeon condition and what, if any, management actions can mitigate the condition. The following section includes discussion of future science actions that will be useful to further understand declining pallid sturgeon condition in the Missouri River.

\section{Information Related to Biology and Health of Pallid Sturgeon}

Fish condition indices are a useful indicator but are confounded by methodological biases and provide little cause/effect understanding about fish health and implications for reproduction. 
It would be useful to move beyond fish condition indices to dependent variables that are more diagnostic of fish health and reproductive potential. For this objective, we recommend four areas for additional scientific effort.

\section{Innovative, Non-Lethal Health Indicators}

It is possible that non-lethal health indicators can provide improvements in assessment tools to evaluate fish health. Proximate analysis - the analysis of tissue composition in terms of major groups such as proteins, water, fats, minerals and carbohydrates - can be used to evaluate condition against a baseline of healthy or unhealthy fish. New methods of proximate analysis use non-lethal bioelectrical impedance (Cox and Hartman, 2005; Hartman and others, 2015) and may be worthy of investigation.

Non-invasive sampling could also include mucous sampling and testing with varying "test strips," although experience with this type of indicator of fish health in Chinook salmon (Oncorhynchus tshawytscha) indicates this is not likely a viable option without significant investment in immunological study and field calibration (M. Colvin, Mississippi State University, oral commun. July 2017).

Biopsies of tissues and blood samples may provide non-lethal indicators of fish health. Muscle plugs can be removed from fish to provide tissue for assessments of contaminants, trace elements, and disease without sacrificing the fish (Ackerson and others, 2014). Muscle plugs have been collected successfully to assess selenium accumulation and stable isotopes in white sturgeon (Acipenser transmontanus; Sun, 2016). Muscle plugs may also provide material for assessment of gene expression of various stressors, including contaminants (Roy and others, 2011). Biopsies are commonly taken on migrating salmon for evaluation of pathogens and other physiological parameters (Crossin and others, 2008).

Blood samples can provide information on various health indicators, with one of the most important being stress as indexed by cortisol levels (Barton and Iwama, 1991; Barton and Dwyer, 1997). If a fish is stressed and exhibits an elevated cortisol response, then immune function and growth could be reduced (Barton and Iwama, 1991; Pickering, 1993; Mommsen and others, 1999). Blood can be taken non-lethally; however, to do this in the field requires centrifugation to separate plasma and chilling prior to storage at -80 degrees Celsius $\left({ }^{\circ} \mathrm{C}\right)$. Lastly, there may be potential to look at other immunological or gene expression methods to evaluate fish health; however, these will require consultation with experts to determine utility.

\section{Fecundity Estimates}

To connect any fish health indicator to population trends, it would be valuable to have reliable fecundity estimates performed routinely on female fish of all origins in the field (through ultrasound) and in the hatchery using ultrasound and counting of eggs. The use of ultrasound in the hatchery provides the opportunity to calibrate gonad volume estimates in the field with actual fecundities, which can be used to link size-dependent gonad volume, fecundity, and condition in the population model. It should be noted that ultrasound tends to overestimate fecundity because fish may or may not release all their eggs when they spawn; calibration with hatchery data will help resolve this fecundity bias. These data will improve understanding of linkages from condition to fecundity and population-level consequences of reduced fish condition. Additionally, egg size should be measured in the hatchery to evaluate the effect of condition on egg health. Fish in a good energetic condition likely produce larger eggs, which improves 
survival and will help disentangle the effect of older fish that potentially have lower fecundity but higher quality eggs.

\section{Necropsies}

A specific opportunity exists to evaluate condition and composition of stored, dead pallid sturgeon. Although the total number of pallid sturgeon preserved by various agencies is unknown, at least 11 exist under the care of Nebraska Game and Parks Commission, with Kn ranging from 0.53 to 1.08 (K. Steffensen, Nebraska Game and Parks Commission, oral commun. July 2017).

This approach would propose that necropsies be performed on all pallid sturgeon that have been frozen and preserved since 2004 to evaluate condition, fat reserves, liver condition, and other cellular or tissue level indicators that may be linked to physiological stress and disease status. Some stored fish may not be amenable to necropsy because they were dead too long before they were collected, were improperly handled, or were stored before being frozen. Nevertheless, the inventory of stored fish among various agencies is probably in the dozens, and some of these are likely to provide good indicators of fish health and condition. Specifically, necropsies may provide additional information about physiological stress, condition, and contaminants status and how these relate to fish condition indexed by relative weight. We are unaware of a sturgeon necropsy program in the United States but necropsies to understand prespawning mortality in spring-run Chinook salmon have been performed (M. Colvin, Mississippi State University, unpub. data, July 2017).

Experience with salmon necropsies did not provide a clear determination of mortality but the lessons learned can provide guidance on how to obtain the most useful and relevant data to assess pallid surgeon health. In the necropsy process, photographs should be taken of all sides of the fish with the fish identity displayed within the photograph. Close-up photographs of any external lesions, infections, or other abnormalities should then be taken. Once the external examination is complete, an internal examination can be conducted by opening the fish and photograph documenting the organs. Once photograph documentation is complete, organ tissue samples can be taken and fixed in formalin for histopathological and contaminants assessment. Histopathological assessment is a low sensitivity assay (that is, low detection probability) but it is not constrained by specificity (Kent and others, 2013). Additionally, histological examination of tissues can evaluate tissue damage as a result of infection. Lastly, the low sensitivity of histology can be remedied by using occupancy approaches to estimate fish level infection or contaminant status (Colvin and others, 2015).

In addition to contaminants and pathogen evaluations, necropsies of pallid sturgeon mortality can provide information useful to assess reproductive and energetic condition. Regardless of gender, the ratio of gonad weight to body weight, known as a gonadal somatic index, can be calculated if the specimen condition is adequate to take weights and no significant freeze drying has occurred. This information can also be incorporated with assessment and potentially validate gonad volumes determined by ultrasound. Energetic status can be evaluated from necropsies by performing proximate analyses of major body tissues (Craig and others, 1978). Proximate analysis can then be used to calibrate non-lethal measurements of energetic status measured by bioelectrical impedance (Cox and Hartman, 2005; Hartman and others, 2015).

Experience with necropsies of salmon provides additional insights that should be taken into account to manage expectations from a necropsy program. The amount of data and samples 
generated from necropsy programs can be significant and require standardized sampling protocols, datasheets, and databases. Additionally, measurements collected to quantify infections or external anomalies need careful consideration. For example, disease severity for multiple pathogens of Chinook salmon was reported on an ordinal scale (0-5), which was difficult to analyze (M. Colvin, Mississippi State University, unpub. data, July 2017). Similarly, the low sensitivity of pathogen detection by histology limited inference, although Colvin and others (2015) provided a method to deal with imperfect detection. Lastly, storing fixed tissue samples was a logistical challenge to archive and curate samples stored in formalin and processed slides.

\section{Early Life and Fish Origin}

The effects of early life exposures in the hatchery system may also contribute to overall fish health. It has been suggested that the growth rates of hatchery-origin fish through subadult stages may vary depending on hatchery of origin (G. Mestl, personal communication). Additionally, the effect of fin curl on the health of hatchery-origin pallid sturgeon in the river system is unclear, albeit Rotella and Hadley (2010) demonstrated a negative effect on survival. Evaluating whether or not growth rates vary in association with hatchery of origin is difficult because pallid sturgeon are allocated among several hatcheries to minimize the risk of losing familial crosses and are also moved among hatcheries; digital records of these moves have not been uniformly captured. Within the National Pallid Sturgeon Stocking Database (U.S. Fish and Wildlife Service, 2006), only the last hatchery before stocking is recorded; however, these fish may have only been reared for a short duration at the recorded hatchery, and any potential effects on fish health may be associated with prior hatcheries. Huenemann (2016) reports some of the egg and larval transfers between hatcheries, but maintaining an audit of movement may be difficult due to multiple moves. This information could be included in the future in a lot-coding system where fish lots are designated with alpha numeric codes that designate the date a lot arrived at a hatchery. For example, 20160601GV-20160801BP-20160815NO is decoded as the fish being originally hatched on June 1 at Gavins Point Hatchery, moved to Blind Pony Hatchery on August 1, and then to Neosho Hatchery on August 15. As long as the date and location coding are consistent and a uniform character is used to mark new date locations, this coding can easily be decoded using a script or logical construct in a database. If there is a system in place where transactions among hatcheries are recorded, we are not aware of it. Such data should be prioritized for entry into a centralized database.

Lastly, determining origin of fish captured as part of monitoring efforts as either wild or hatchery origin and aligning hatchery-origin fish with hatchery information proved to be challenging for this analysis. Efforts to unify genetic assignments, hatchery records, pedigrees, and capture-recapture data are likely to be of critical importance in understanding causes and consequences of declining condition.

\section{Information Related to Pallid Sturgeon Within the Missouri River Ecosystem}

\section{Pallid Sturgeon Condition and Energetics}

Energetics govern the accumulation (that is, growth) and loss of biomass at a population and individual level. Growth occurs when consumption is sufficient to offset losses due to metabolism, excretion, unassimilated food, and other behaviors that require energy (for example, migration, movement). Biomass losses can occur when energetic demands are greater than 
consumption or when the composition of consumption changes due to availability of prey items with lower energy content. Energetics dynamics can be evaluated at the ecosystem level (ecoenergetics) where populations are viewed as biomass and biomass is moved through the food web by consumption. Energetics can also be evaluated at the individual level (bioenergetics) where consumption is moved through a fish's body. These approaches may provide understanding of the mechanisms associated with reduced pallid sturgeon condition in the Lower Missouri River, albeit with advantages and disadvantages. Approaches are detailed in the following sections.

\section{Ecoenergetics}

Interspecific and intraspecific competition for food resources can result in reduced pallid sturgeon condition. Additionally, if prey resources decline as a result of changes in primary productivity or energy is diverted into trophic levels that are not available to pallid sturgeon, there can be energetic consequences. For example, invasive species can modify trophic flows within a food web and divert energy that would otherwise be used by pallid sturgeon. The classic example of this is the introduction of zebra mussels into freshwater systems that resulted in primary productivity being diverted to benthic food webs, thereby limiting trophic support for the pelagic food web (Rutherford and others, 1999; Simon and Townsend, 2003). Within the Lower Missouri River system, the ongoing invasion of Asian carps may alter the trophic flows because these fish prey on zooplankton, which in turn may limit production of zooplantivorous fish like sturgeon chub and sicklefin chub. Reduced zooplanktivorous fish production may then limit pallid sturgeon growth. Similar effects may be associated with other invasive species, such as zebra mussels, although the extent is presently unknown.

Interactions of primary producers and consumers within a food web can be complex, and evaluating the effect of competition, density dependence, invasive species, and other mechanisms limiting pallid sturgeon prey resources may be challenging. Commonly used biomass dynamics models assume that total population biomass will not increase once carrying capacity is reached (Graham, 1935; Ricker, 1975); however, conventional models of fish biomass dynamics apply to single populations. It is recognized that fish populations interact through predation and other mechanisms within a food web. Food-web interactions can be evaluated at the ecosystem level using ecoenergetic models that differ from traditional fishery models, which forecast biomass dynamics for single populations, by forecasting biomass dynamics for the entire food web. In these models, biomass is moved within a food web from prey to predator through predation and biomass is added to the predator population after accounting for losses of unassimilated food. The most commonly used ecoenergetics model for modeling aquatic food webs is Ecopath with Ecosim (EwE; Polovina, 1984; Walters and others, 1997; Christensen and Walters, 2004).

The EwE approach is recognized as the state-of-the-art approach to evaluating ecosystem dynamics in aquatic systems. It was developed and has been applied in many marine and estuarine systems. Application of EwE to freshwater has been limited, especially in open, flowing lotic systems. Specifically, the EwE model as currently developed does not easily allow for drift into downstream reaches. Additionally, because the model treats the food web as a single entity, attempting to model multiple reaches, each with a unique food web, requires separate models and links to account for drift of material such as primary production, invertebrates, and detritus. The Ecospace component of EwE is designed to provide spatially explicit modelling of populations but not the movement of water (Walters and others, 1999; 
Pauly and others, 2000). Overall, a tool like EwE may be a useful framework to examine the potential for pallid sturgeon biomass changes as a result of changes in system productivity, addition of invasive species, or competition within and among species; however, some modification of the existing EwE framework would likely be necessary to adequately model pallid sturgeon biomass and food-web dynamics in a system like the Missouri River. These modifications would likely require separate but coupled Ecopath models for major Missouri River segments that account for downstream drift and tributary inputs. The STELLA (www.iseesystems.com) framework developed in Colvin (2012) replicates the EwE framework but can couple multiple Ecopath models together to adequately represent the natural hierarchical organization of major river segments in the Lower Missouri River system.

An advantage to using this type of model is the holistic approach. An entire food web must be carefully built with scrutiny of parameter inputs and diet compositions for each foodweb component. This process in itself is useful because it would assimilate what is known about the Lower Missouri River food web and identify information gaps as they relate to understanding food-web dynamics. Although the parameterization may require many estimates, the EwE approach requires fewer parameters than more complicated ecosystem models (for example, Atlantis) (M. Colvin personal observation). Additionally, there are many empirical estimators that can be used to predict values needed to parameterize the model (for example, Palomares and Pauly, 1998; Randall and Minns, 2000; Liao and others, 2005). One disadvantage to using an ecoenergetics approach is that populations, like pallid sturgeon, are treated as biomass pools and therefore a loss in the condition of individuals is impossible to disentangle beyond changes in mean weight or total biomass of the population over time. Food-web models can also become complicated with numerous groups represented, especially as the groups relate to taxa of interest. Specifically, food-web models tend to account for all fish species, whereas primary and secondary producers are lumped into similar trophic groups. Overall, this approach can provide insight into the effects of food-web changes as a result of invasive species or changes in prey fish populations, but the effects of these changes on individual fish, like the "skinny" fish observed in the Lower Missouri River below Gavins Point Dam, might be obfuscated.

\section{Bioenergetics}

Poor condition in fish is a characteristic that is observed at the individual fish level. Examining what environmental factors are required to decrease fish condition, and over what timeframe, will be valuable to understanding potential associations of consumption, water temperature, and flow on pallid sturgeon condition. Bioenergetics models are an approach that 
can be used to evaluate the effect of factors acting on an individual fish weight. The governing equation of fish bioenergetics is
where$$
C=G+R+F+U
$$
C is energy consumption,
$G \quad$ is growth,
$R \quad$ is the total metabolic rate (basal metabolism plus additional costs associated with activity and food digestion),
$F \quad$ is energy lost by egestion (feces), and
$U \quad$ is the cost of excretion nitrogenous waste.

Equation 4 is rearranged so that $G$ is predicted as a function of $C, R, F$, and $U$ (Kitchell and others, 1974; Kitchell and others, 1977). Using the growth formulation, consumption is calibrated given $R, F$, and $U$ to match growth rates observed in nature. Parameters are usually derived from lab experiments (Bevelhimer, 2002; Deslauriers and others, 2016) and used to simulate growth under varying thermal profiles and flow conditions. Similar to the EwE approach, there are many parameters that are required to simulate biomass dynamics with useful accuracy using the model. Specifically, the components listed in equation 4 are further broken down to provide biological realism and simulate growth or consumption as a function of temperature and activity. Values of respiration, specific dynamic action, prey densities, predator densities, optimal temperatures, growth, basal metabolism, active metabolism, egestion, and excretion may all be important to estimate. Typically, these parameters are derived from laboratory experiments, borrowed from similar species, or a combination of the two.

Given that a bioenergetics model can model growth for a given time, it stands to reason that this model could be used to evaluate under what conditions body mass losses occur that result in low condition. For example, in a scenario where a fish was not consuming any food, the amount of time required to lose weight and achieve a low condition can be calculated. Similarly, the effect of changes in environmental factors like temperature and flow on weight can be simulated, and the conditions required to achieve low-condition fish might be identified.

Many bioenergetics models have been developed for sturgeon species. Bevelhimer (2002) developed a generic model for white sturgeon in the Snake River, Idaho. Pallid sturgeon bioenergetics models have been developed for age-0, older juveniles, and adults (Heironimus, 2014; Wildhaber, Dey, and others, 2015; Deslauriers and others, 2016). These pallid sturgeon models use laboratory estimates for small age- 0 and older juveniles to parameterize the model, which may not be realistic for adult fish. Recently, Walters and Essington (2010) presented an approach to estimate parameters for bioenergetics models using a Bayesian framework and informative priors on confounded bioenergetics parameters. This approach could provide a way to estimate bioenergetics model parameters and associated uncertainties by incorporating lab estimates from Deslauriers and others (2016) and Heironimus (2014) and capture-recapture data for pallid sturgeon in the PSPAP database. As part of this report, we attempted to reconstruct pallid sturgeon bioenergetics models reported in the literature independently; however, simulated growth was not realistic, required parameters were not reported, and (or) parameter units were not reported. These problems are common in the field of bioenergetics literature and given the time constraints of this analysis; follow-up will be required if this type of analysis proceeds to examine conditions that may lead to reduced pallid sturgeon condition. 


\section{Diets and Trophic Position}

Pallid sturgeon diets can be assessed through various approaches to determine whether diet is limiting to growth and condition. It is of particular interest whether juvenile pallid sturgeon are able to make the ontogenetic dietary shift from invertebrates to fish, which is a shift that has been identified in the literature and is thought to be bioenergetically necessary for pallid sturgeon (Gerrity and others, 2006; French and others, 2013; Wildhaber, Wikle, and others, 2015). Stomach contents can be sampled through gastric lavage and evaluated through identification of body parts (Gerrity and others, 2006). This process is time consuming and gastric lavage can be stressful on fish. Alternative approaches may be to develop deoxyribonucleic acid (DNA) methods to identify prey species DNA markers in pallid sturgeon feces (Jo and others, 2016). The eDNA in feces can be used to document presence or absence of prey fish and invertebrates species in the pallid diet, and thereby indicate whether adults have been able to make the switch to piscivory. The eDNA can also be used to test water samples for presence of prey fish species. Comparisons between river reaches with diminished pallid sturgeon condition to reaches where condition is higher can be used to implicate prey fish as a limiting factor.

A diet shift or lack of prey resources will result in a change in the trophic signature of pallid sturgeon. The trophic signature of organisms is a function of the food they eat and assimilate and is indexed by the ratio of stable isotopes in the organism by the process of step fractionation (Mill and others, 2007). As prey is consumed and assimilated, the fraction of stable isotopes changes (for example, carbon, nitrogen, sulfur). Specifically, nitrogen isotopes indicate trophic position because predators accumulate ${ }^{15} \mathrm{~N}$ isotopes from prey because it is heavier than

${ }^{14} \mathrm{~N}$. If the isotopic signature of predator and prey are known (that is, ratio of ${ }^{15} \mathrm{~N}:{ }^{14} \mathrm{~N}$ ), diet composition can be inferred by identifying the most likely mixture of prey items that result in the isotopic signature of the predator. Similar to otolith microchemistry, hard structures like fin rays may be used to evaluate large shifts in trophic level by examining the ratio of ${ }^{15} \mathrm{~N}:{ }^{14} \mathrm{~N}$ to potentially identify ontogenetic shifts and shifts to no consumption. In the case of no consumption, it would be expected that fish with low conditions would exhibit a higher isotopic signature because they are using stored energetic sources. Assimilation of energetic sources varies among tissues and therefore changes in the isotopic signature may take longer to realize in structural tissue like bone or other hard structures (Phillips and Eldridge, 2006; Church and others, 2009). Caution must be used to identify the best tissue to evaluate changes in the isotopic signature.

The effectiveness of stable isotopes to evaluate starvation will likely require some pilot research to investigate the utility. Isotopic analysis of hard structures, such as the otoliths of fish, has been done in the past (Radtke and others, 1996) and non-lethal examination of stable isotopes in shovelnose sturgeon has been done by DeVries and Schramm (2015). It is unclear whether fine-scale isotopic signatures can be evaluated on a cross-section of a hard structure to provide a temporal context for when isotopic shifts occur. Alternatively, DeVries and Schramm (2015) noted that the difference in turnover rate between pectoral spine and fin clip might be complementary, providing evaluation of trophic position at different times because fin tissue turns over at a higher rate than pectoral tissue. In the larger context, stable isotope work can integrate with ecoenergtic modeling to inform diet compositions and trophic levels that can be used to constrain mass balance of biomass production (van Oevelen and others, 2010; Deehr and others, 2014). Isotopic data can also be used in a bioenergetics approach by providing realistic estimates of diet composition. 


\section{Information Related to Missouri River Habitat Dynamics}

Physical habitat changes hypothesized to occur over decades are poorly documented at a scale amenable to quantification for pallid sturgeon. Depth and velocity measurements at streamgages are frequent (multiple times per month) but spatially non-representative of the available habitat in the river. Bathymetric cross-sections for engineering purposes cover the entire river but typically are not close enough to one another to create computational meshes for hydrodynamic models. Existing multidimensional hydrodynamic models at a scale and resolution suitable for habitat assessments (Jacobson, Annis, and others, 2016) do not adequately address morphological changes relevant to the fish-condition hypotheses. For some Lower Missouri River reaches, there are high-resolution bathymetric and topographic data that were collected in the 2005-09 timeframe and may be amenable to analysis of short-term habitat change. The USGS Comprehensive Sturgeon Research Project surveyed many river reaches from 2006 to 2009 as part of the subproject Sturgeon Response to Flow Modifications (SRFM). These reaches have been documented (Reuter and others, 2009) and original data files are available from USGS. For example, 20 reaches were mapped between Omaha and St. Joseph, Mo., in 2005 and 2006. The hydroacoustic mapping in the SRFM project includes depths, velocities, substrate, and some derivative variables for reaches that encompassed bend-crossover-bend combinations, usually several kilometers in length. The derivative maps are at 5-m resolution, interpolated from cross-sectional transects spaced 20-40 m. Although these datasets did not include elevation control, resurveys of the reaches could be used to evaluate net change in distributions of depths, velocities, and habitat categories (at comparable discharges) from before the 2011 flood to a more-recent date.

The hypothesis that spatial variation in habitat availability and bioenergetic costs is linked to variability in fish condition may be addressed by habitat selection studies. Telemetry studies on adult pallid sturgeon have previously focused on reproductive migrations rather than foraging. Detailed tracking of foraging adults, combined with detailed habitat characterization in foraging areas (depths, velocity fields, and derivatives) would serve to document energy expended in feeding. A systematic comparative study between river reaches with diverse habitats and higher Kn (for example, segment 14) and river reaches with less diverse habitats and declining Kn (for example, segment 9) may document differential energy requirements by river reach.

Water quality has been hypothesized as a variable that could potentially affect pallid sturgeon condition, although clear linkages are lacking (Blevins, 2011; Jacobson, Annis, and others, 2015; Jacobson, Annis, and others, 2016). Notwithstanding the lack of clear linkage from common water quality parameters (temperature, turbidity, and dissolved oxygen), the fundamental role of these water quality parameters in defining the aquatic ecosystem indicates that a continued effort to monitor them is warranted, at least to understand potential covariates.

Bioaccumulation of contaminants is another habitat variable that could potentially affect adult sturgeon condition. As documented in the EA reports, municipal, industrial, and agricultural sources of wastewater along the Lower Missouri River present a potential for exposure, but direct evidence of effects on pallid sturgeon is missing (Jacobson, Annis, and others, 2015; Jacobson, Annis, and others, 2016). Of potential contaminants, accumulation of forms of selenium through food items may be a concern because it has been associated with starvation of white sturgeon juveniles (Zee and others, 2016); selenium concentrations in water in the Lower Platte, Tongue, and Powder rivers have also been cited as concerns (M. Webb, written commun., 2014). Contaminants like atrazine, polychlorinated biphenyls (PCBs), and 
dioxin have been associated with reproductive anomalies or endocrine system dysfunction in other fish species; however, available data indicate that effects levels are generally not achieved on the Missouri River (Tillitt and others, 2004; Papoulias and others, 2010; Buckler, 2011) and there has been no evidence linking adult growth or condition to such contaminants. Nevertheless, necropsies of preserved sturgeon and non-lethal muscle sampling may be justified, at least at a screening level, to assess whether these or other contaminant mixtures might be implicated.

\section{Information Management}

A systematic approach to testing and eliminating hypotheses for diminished pallid sturgeon condition would be supported by an increased emphasis on data management. During this analysis, the team identified specific concerns while evaluating information in pallid sturgeon datasets (for example, difficulty in discriminating wild-origin from hatchery-raised fish or in compiling hatchery histories). These data gaps prevented rigorous analyses of the potential effects of origin on fish condition.

Our analysis also demonstrated the value and need for long-term datasets that track health of individual fish. Because the importance of fish condition is manifest ultimately at the population level, the effects of condition on demographic rates (fecundity, egg size, egg viability, sperm quality, intervals between spawning, age at first spawning, rate of atresia) are particularly important. Such rate information is only available through telemetry or mark/recapture programs that keep track of individual fish during multiple reproductive cycles.

\section{Summary and Conclusions}

This report was requested by the U.S. Army Corps of Engineers Missouri River Recovery Program (MRRP) to address emerging information about declining condition in pallid sturgeon. The joint fact-finding team was assembled through the Missouri River Pallid Sturgeon Effects Analysis (EA) and was charged with providing the MRRP, and associated agencies and stakeholders, with an additional level of review of information presented by the Nebraska Game and Parks Commission and documented in two research articles (Steffensen and Mestl, 2016; Steffensen and others, 2016). The extra level of review and synthesis were requested because of the potential importance of declining fish condition to substantive management decisions in avoiding jeopardy to the pallid sturgeon.

The team was charged with two areas of focus:

- Is there evidence that pallid sturgeon in the Lower Missouri River are in poor and (or) declining condition? What is the level of uncertainty in the conclusions?

- What is the likely cause of the poor condition? What is the level of uncertainty in the conclusion?

Our analysis addressed the first question by using methods that were different and complementary to those used by Nebraska Game and Parks Commission (Steffensen and Mestl, 2016; Steffensen and others, 2016). The complementarity of our approach provided a robust test of the issue, albeit dependent on the same fundamental datasets.

From our analysis we determined with certainty that average condition of pallid sturgeon has declined since 2012 relative to the 2005-11 average, particularly in the Lower Missouri River. Apparent trends in the upper basin seem to have been created by fish recruiting into lengths where the Shuman Kn had a poor fit and reported erroneously low Kn. Documentation of trends and attempts to develop cause and effect are complicated by variability. For example, not 
all sturgeon are affected equally; even in segments where declines in Kn are substantial, there continue to be sturgeon captured in robust condition. Some of the data support segment and bend effects. Segment effects, especially the severity of decline in segment 9, seem robust. At the bend level, effects seem localized with nearby bends having very different distributions of fish condition. Variation in condition with size and hatchery origin may also be present, but these effects are confounded with the sturgeon population dynamics resulting from low natural recruitment, high rates of hatchery stocking, and aging of the wild population.

We did not determine with certainty whether the trend of low condition will continue, worsen, or improve. The downward trend in the Lower Missouri River has only been evident for 3 years, and the trend for the latest year (2016) is no longer downward; it is either level or slightly recovering. This is a short time in pallid sturgeon population dynamics and in river dynamics. Without a clear understanding of a driving process, it is not possible to forecast future responses. Our assessment is that although the recent trend in condition is fairly certain, the future is highly uncertain. The trends warrant continued, careful monitoring.

The second question to the team was about the likely cause of the poor condition. We conclude that there is presently no clear connection to a specific cause or causes. Some of the empirical information is contradictory and most is incomplete. Rapid declines in condition in 2012-14 indicate response to a transient event, with the flood of 2011 being a clear candidate. The rapid changes argue against overstocking as a sole cause because it is unlikely that overstocking effects would be apparent in a short timeframe. Equal rates of fish in poor condition at stages before and after the expected shift to full piscivory indicate that lack of prey fish, alone, was likely not a causal factor.

The team considered several hypotheses to explain declining condition. We are aware that there may not be a single cause for declining condition. Causes may be different in different places along the river and interactions among processes may result in complex responses, such as when a chronic condition is suddenly exacerbated by an event that crosses a threshold. Scenarios that include interacting habitat changes, predator/prey dynamics, and intra- and interspecific competition need be considered. The following hypotheses were among those considered:

- Diminished fish health, related either to hatchery practices or to contaminant exposure.

- Intraspecific competition resulting from overstocking and high survival of hatcheryorigin fish. The population of pallid sturgeon has overshot the carrying capacity of the river ecosystem, primarily by depletion of prey.

- Interspecific competition. For example, removal of commercial fishing pressure on shovelnose sturgeon in part of the range or expansion of Asian carp may have depleted or altered the local food webs in such a way as to reduce available food resources for pallid sturgeon.

- Spatial resource competition. Long-term channel adjustments to the dams and the Bank Stabilization and Navigation Project, with or without transient adjustments due to extreme events like the 2011 flood, have rearranged the channel morphology in such a way as to provide less bioenergetically favorable habitat for pallid sturgeon or their prey base.

- Observed variation in condition are the normal range of variability and declines reflect a return to normality; that is, the condition factors from 2012 to present (2017) represent a more normal population level.

- Senescence. This hypothesis holds that some of the large, low-condition fish in the Lower Missouri River may be older, wild-origin fish reaching the end of their lifespan. 
We believe that there is little support for concern about fish health from hatchery releases. First, there is little difference in condition between wild- and hatchery-origin fish. Second, despite stocking in the upper and lower basins, there are more fish in low condition in the lower basin. Finally, the decrease in condition does not temporally correspond to any change in stocking efforts.

Our analysis focuses on low condition as defined statistically (more than one standard deviation below the mean of the population); however, there is very little background information presently available to define what normal condition of the pallid sturgeon population on the Missouri River should be, or how low (or high) Kn is likely to affect population dynamics. Despite this lack of information, concern about low and declining Kn values seems to be valid.

We determined that there may be some support for a senescence hypothesis to explain a minor portion of the fish in low condition and, in particular, to explain some of the large reproductive adults in very low condition encountered during the broodstock collection program. If there has been little natural recruitment since the closing of the mainstream dams, then this portion of the population is approaching 60 or more years old, and one would expect to start to see fish in declining condition as they age out of the population; however, senescence does not explain all of the trend. There are large numbers of hatchery-origin fish in low condition. Senescence also does not explain the temporal trend; there is no reason why condition should have started to decline suddenly starting in 2012 .

The timing, distribution, and duration of the low-condition episode indicate that several of our hypotheses may be in play at the same time, each contributing to the low condition in some degree. First, the stocking and survival levels of hatchery fish have greatly increased the stock size and biomass of pallid sturgeon in the system. Although it is almost impossible to predict the carrying capacity of the system, an increase in the number, size, and biomass of pallid sturgeon likely places a degree of stress on the system. Secondly, the population of Asian carp has increased. Although not a direct competitor with pallid sturgeon, it is not unusual to determine that the increase of an invasive species has environmental effects that are not foreseen, and system linkages become apparent only after the fact. We determined that the strong decline following record floods implies some flood-specific contribution. Although the flood created a boom in terms of nutrients and resources available to pallid sturgeon, such as reconnection to flood plains, creation of favorable hydrodynamic niche space, and increased spawning and recruitment of prey species, it also may have set the stage for a subsequent bust by deepening the channel and leaving less connectivity and niche space available once the water receded.

In general, we conclude that the reports of low condition are valid and a cause for concern, but not yet a cause for panic. The trend is not systemic and may be reversing. It was clearly either caused or exacerbated by the record floods of 2011. There are valid concerns that the stocking programs may have overshot program goals due to higher-than-expected survival levels; however, there is not yet enough evidence to indicate that the carrying capacity of the river has been exceeded.

\section{Disposition of the Fish-Condition Issue}

The charge to the team included asking for a recommendation of how to proceed with the fish-condition issue, including the following possibilities:

1. The issue lacks merit so no further work recommended.

2. Lack of sufficient data and (or) metrics preclude analysis or provide inconclusive results. 
3. The issue has merit but there is too much uncertainty to recommend action. To reduce uncertainty, it is recommended that additional science efforts are needed.

4. The problem and cause are clear enough to recommend remedial action, including all recommended actions (even those that may be outside USACE's purview) as well as the confidence level that actions will produce the desired result.

The team is in agreement that the issue has merit, but the causal mechanism(s) have too much uncertainty to recommend a specific management action; that is, we do not know enough yet to recommend management actions such as reducing stocking rates, removing competing fish species, or reconfiguring the channel to decrease velocities. Instead, we recommend investment in focused research and assessment actions that will serve to narrow the field of possible causes. Once the field is sufficiently narrow (that is, not requiring certainty) management actions can be undertaken within an adaptive management framework, following the four levels introduced in the Missouri River Science and Adaptive Management Plan (Craig Fischenich, U.S. Army Corps of Engineers, written commun. July 2017).

\section{Prioritization of Science Needs}

Our recommendation of priority science needs is based on our understanding of information benefits relative to costs. Ultimately, prioritized implementation of science components is a policy decision that will be based on MRRP determinations of value. Science needs can be addressed sequentially to pursue first the more easily attainable actions that will maximize information at the lowest cost. Conversely, science topics that appear later in the list may be more fundamental to understanding the pallid sturgeon and the river, but priority may be lower because of the cost.

The primary science need is to continue to monitor pallid sturgeon condition to understand trends. Effective monitoring of condition factor can be complemented with non-lethal tissue and blood sampling that can be used to assess cortisol levels, gene expression of starvation, contaminants, and stable isotopic signatures of dominant diet. If condition continues to decline to the point where it is affecting reproductive potential, resource-management agencies may consider bringing reproductive-age fish into hatcheries to recondition the fish.

Although most of the available data were assessed in our review, there may be additional information available to identify covariates and environmental data. Additional data mining of field sheets for environmental data would be a relatively low-cost project that would improve context for this question.

A specific type of data mining that was not possible during the team's tenure would be to more thoroughly examine individual fish histories of captures, condition, and reproductive status. This type of data mining would require some investment in developing or improving data relations among existing sturgeon databases.

An investment in necropsies for all stored, dead pallid sturgeon would be valuable. Exploring common threads among these mortalities could be accomplished with a phased approach, starting with a low-cost, qualitative analysis and proceeding to more detailed analysis if warranted. Simple assays, such as lipid composition or assessments for parasite load or disease status, may provide key insights into fish condition trends.

To address a key hypothesis about diet deficiencies - that juvenile to adult pallid sturgeon are not finding prey fish with sufficient caloric value-we recommend investment in diet studies including the use of environmental deoxyribonucleic acid (eDNA) in feces, stable isotope composition of muscle tissue, or other diet methods. Because Kn values indicate that fish at a 
wide range of sizes are in poor condition and correlations between $\mathrm{Kn}$ and prey fish catch per unit effort are equivocal, diet alone is likely not solely responsible for declining condition, but it may be a contributor.

To test hypotheses about interactions with habitat degradation, we recommend mining of habitat data to elucidate recent habitat changes that could be related to declining condition. In addition, comparative telemetry studies on foraging behaviors and energy expenditures could provide insights into causal bioenergetic mechanisms. Such studies might compare, for example, "skinny" fish in segment 9 to "fat" fish in segment 14. The studies would look at movement rates required for foraging, habitat selection relative to energy requirements, and potentially habitat selection relative to Asian carp locations.

The team determined that mining of the Pallid Sturgeon Population Assessment Project database provided some useful insights, but testing of hypotheses about interactions between pallid sturgeon Kn, competing species, and prey species may require more specific study designs. We envision that sampling for suspected competitors and prey species along habitat- or $\mathrm{Kn}$-defined gradients would provide more robust statistical analysis and insight into these hypothesized relations.

The foregoing set of science needs may answer many questions and could resolve information needed to move to the next step, either a field experiment or implementation at a level intended to elicit a population-level response. If information remains ambiguous about causes for declining condition, it may be useful to proceed with more ecologically based measurement and modeling by implementing ecoenergetics or bioenergetics. Return on investment from these types of models is uncertain because of the large number of assumptions and parameters that must be estimated. Investment would be warranted if more empirical data do not resolve key questions. If a subset of these science actions provides strong support for a causal mechanism, the next step under the MRRP adaptive management plan framework would be to carry out field-based experiments. Following field-based experimentation, and assuming that a working hypothesis has emerged, level 3 implementation of a mitigating action would be at a scale that would produce a measurable population response. If confirmed through monitoring and assessment, level 4 implementation would be at a scale meant to sustain the population (Fischenich and others, In Review). 


\section{References Cited}

Ackerson, J.R., McKee, M.J., Schmitt, C.J., and Brumbaugh, W.G., 2014, Implementation of a non-lethal biopsy punch monitoring program for mercury in smallmouth bass, Micropterus dolomieu Lacepède, from the Eleven Point River, Missouri: Bulletin of Environmental Contamination and Toxicology, v. 92, no. 2, p. 125-131, [Also available at http://dx.doi.org/10.1007/s00128-0131145-x.]

Barton, B.A., and Dwyer, W.P., 1997, Physiological stress effects of continuous- and pulsed-DC electroshock on juvenile bull trout: Journal of Fish Biology, v. 51, no. 5, p. 998-1008, [Also available at http://dx.doi.org/10.1111/j.1095-8649.1997.tb01538.x.]

Barton, B.A., and Iwama, G.K., 1991, Physiological changes in fish from stress in aquaculture with emphasis on the response and effects of corticosteroids: Annual Review of Fish Diseases, v. 1, p. 3-26, [Also available at http://dx.doi.org/10.1016/0959-8030(91)90019-G.]

Bettoli, P.W., Casto-Yerty, M., Scholten, G.D., and Heist, E.J., 2009, Bycatch of the endangered pallid sturgeon (Scaphirhynchus albus) in a commercial fishery for shovelnose sturgeon (Scaphirhynchus platorynchus): Journal of Applied Ichthyology, v. 25, no. 1, p. 1-4, [Also available at http://dx.doi.org/10.1111/j.1439-0426.2008.01183.x.]

Bevelhimer, M.S., 2002, A bioenergetics model for white sturgeon Acipenser transmontanus: Assessing differences in growth and reproduction among Snake River reaches: Journal of Applied Ichthyology, v. 18, no. 4-6, p. 550-556, [Also available at http://dx.doi.org/10.1046/j.14390426.2002.00392.x.]

Bland, J.M., and Altman, D.G., 1995, Multiple significance tests - the Bonferroni Method: British Medical Journal, v. 310, no. 6973, p. 170-170, [Also available at https://www.ncbi.nlm.nih.gov/pubmed/7833759.]

Blevins, D.W., 2006, The response of suspended sediment turbidity, and velocity to historical alternations of the Missouri River: U.S. Geological Survey Circular 1301, 8 p., [Also available at https://pubs.er.usgs.gov/publication/cir1301.]

Blevins, D.W., 2011, Water quality requirements, tolerances, and preferences of pallid sturgeon (Scaphirhychus albus) in the Lower Missouri River: U.S. Geological Survey Scientific Investigations Report 2011-5186, 20 p., [Also available at https://pubs.er.usgs.gov/publication/sir20115186.]

Braaten, P.J., Fuller, D.B., Lott, R.D., Haddix, T.M., Holte, L.D., Wilson, R.H., Bartron, M.L., Kalie, J.A., DeHaan, P.W., Ardren, W.R., Holm, R.J., and Jaeger, M.E., 2012, Natural growth and diet of known-age pallid sturgeon (Scaphirhynchus albus) early life stages in the Upper Missouri River basin, Montana and North Dakota: Journal of Applied Ichthyology, v. 28, no. 4, p. 496-504, [Also available at http://dx.doi.org/10.1111/j.1439-0426.2012.01964.x.]

Bramblett, R.G., and White, R.G., 2001, Habitat use and movements of pallid and shovelnose sturgeon in the Yellowstone and Missouri Rivers in Montana and North Dakota: Transactions of the American Fisheries Society, v. 130, no. 6, p. 1006-1025, [Also available at http://dx.doi.org/10.1577/1548-8659(2001)130<1006:Huamop>2.0.Co;2.]

Buckler, J., 2011, Persistent organic pollutant effect on middle Mississippi River Scaphirhynchus sturgeon reproduction and early life stages: Columbia, Mo., University of Missouri, M.S. thesis, 154 p., [Also available at https://mospace.umsystem.edu/xmlui/bitstream/handle/10355/14530/research.pdf?sequence $=2$.]

Bulliner, E.A., Elliott, C.M., and Jacobson, R.B., 2017, Acoustic Doppler current profiler raw measurements on the Missouri and Yellowstone rivers, 2000-2016, Columbia Environmental Research Center, U.S. Geological Survey data release at https://doi.org/10.5066/F7X34VND. 
Burnham, K.P., and Anderson, D.R., 2002, Model selection and multimodel inference. A practical information-theoretic approach: New York, NY, Springer.

Cade, B.S., Terrell, J.W., and Neely, B.C., 2011, Estimating Geographic Variation in Allometric Growth and Body Condition of Blue Suckers with Quantile Regression: Transactions of the American Fisheries Society, v. 140, no. 6, p. 1657-1669, [Also available at http://dx.doi.org/10.1080/00028487.2011.641885.]

Christensen, V., and Walters, C.J., 2004, Ecopath with Ecosim: methods, capabilities and limitations: Ecological Modelling, v. 172, no. 2-4, p. 109-139, [Also available at http://dx.doi.org/10.1016/j.ecolmodel.2003.09.003.]

Church, M.R., Ebersole, J.L., Rensmeyer, K.M., Couture, R.B., Barrows, F.T., and Noakes, D.L.G., 2009, Mucus: a new tissue fraction for rapid determination of fish diet switching using stable isotope analysis: Canadian Journal of Fisheries and Aquatic Sciences, v. 66, no. 1, p. 1-5, [Also available at http://dx.doi.org/10.1139/f08-206.]

Clarke, R.D., 1992, Effects of microhabitat and metabolic rate on food intake, growth and fecundity of two competing coral reef fishes: Coral Reefs, v. 11, no. 4, p. 199-205, [Also available at http://dx.doi.org/10.1007/BF00301994.]

Colvin, M.E., 2012, Impacts of non-native species in a shallow lake: a simulation modeling approach for restoration and management: Iowa State University, Ph.D. Dissertation, 315 p., [Also available at http://lib.dr.iastate.edu/etd/12549/.]

Colvin, M.E., Peterson, J.T., Kent, M.L., and Schreck, C.B., 2015, Occupancy modeling for improved accuracy and understanding of pathogen prevalence and dynamics: PLoS ONE, v. 10, no. 3, p. e0116605, [Also available at http://dx.doi.org/10.1371\%2Fjournal.pone.0116605.]

Cox, M.K., and Hartman, K.J., 2005, Nonlethal estimation of proximate composition in fish: Canadian Journal of Fisheries and Aquatic Sciences, v. 62, no. 2, p. 269-275, [Also available at http://dx.doi.org/10.1139/f04-180.]

Craig, J.F., Kenley, M.J., and Talling, J.F., 1978, Comparative estimations of the energy content of fish tissue from bomb calorimetry, wet oxidation and proximate analysis: Freshwater Biology, v. 8, no. 6, p. 585-590, [Also available at http://dx.doi.org/10.1111/j.1365-2427.1978.tb01480.x.]

Crossin, G.T., Hinch, S.G., Cooke, S.J., Welch, D.W., Patterson, D.A., Jones, S.R.M., Lotto, A.G., Leggatt, R.A., Mathes, M.T., Shrimpton, J.M., Van der Kraak, G., and Farrell, A.P., 2008, Exposure to high temperature influences the behaviour, physiology, and survival of sockeye salmon during spawning migration: Canadian Journal of Zoology-Revue Canadienne De Zoologie, v. 86, no. 2, p. 127-140, [Also available at http://dx.doi.org/10.1139/Z07-122.]

Deehr, R.A., Luczkovich, J.J., Hart, K.J., Clough, L.M., Johnson, B.J., and Johnson, J.C., 2014, Using stable isotope analysis to validate effective trophic levels from Ecopath models of areas closed and open to shrimp trawling in Core Sound, NC, USA: Ecological Modelling, v. 282, p. 1-17, [Also available at http://dx.doi.org/10.1016/j.ecolmodel.2014.03.005.]

DeLonay, A.J., Jacobson, R.B., Papoulias, D.M., Simpkins, D.G., Wildhaber, M.L., Reuter, J.M., Bonnot, T.W., Chojnacki, K.A., Korschgen, C.E., Mestl, G., and Mac, M.J., 2009, Ecological requirements for pallid sturgeon reproduction and recruitment in the Lower Missouri River: A research synthesis 2005-08: U.S. Geological Survey Scientific Investigations Report 2009-5201, 59 p.

Deschenes, J., and Rodriguez, M.A., 2007, Hierarchical analysis of relationships between brook trout (Salvelinus fontinalis) density and stream habitat features: Canadian Journal of Fisheries and Aquatic Sciences, v. 64, no. 5, p. 777-785, [Also available at http://dx.doi.org/10.1139/f07-053.]

Deslauriers, D., Heironimus, L.B., and Chipps, S.R., 2016, Test of a foraging-bioenergetics model to evaluate growth dynamics of endangered pallid sturgeon (Scaphirhynchus albus): Ecological Modelling, v. 336, p. 1-12. 
DeVries, R.J., and Schramm, H.L., 2015, Similarities and differences in $13 \mathrm{C}$ and $15 \mathrm{~N}$ stable isotope ratios in two non-lethal tissue types from shovelnose sturgeon Scaphirhynchus platorynchus (Rafinesque, 1820): Journal of Applied Ichthyology, v. 31, no. 3, p. 474-478, [Also available at http://dx.doi.org/10.1111/jai.12708.]

Dick, E.J., 2009, Modeling the reproductive potential of rockfishes (Sebastes spp.) University of California Santa Cruz, PhD.

Doyle, M., Murphy, D., Bartell, S., Farmer, A., Guy, C.S., Palmer, M., and Turner, R., 2011, Final report on spring pulses and adaptive management: Missouri River Recovery Program Independent Science Advisory Panel: U.S. Institute for Environmental Conflict Resolution, 58 p., [Also available at http://projects.ecr.gov/moriversciencepanel/pdfs/MRISAPFinalReportSpringPulseAdaptMgt113011.pdf.]

Ebersole, J.L., Colvin, M.E., Wigington, P.J., Leibowitz, S.G., Baker, J.P., Church, M.R., Compton, J.E., and Cairns, M.A., 2009, Hierarchical modeling of late-summer weight and summer abundance of juvenile coho salmon across a stream network: Transactions of the American Fisheries Society, v. 138, no. 5, p. 1138-1156, [Also available at http://dx.doi.org/10.1577/T07-245.1.]

Einum, S., Nislow, K.H., Reynolds, J.D., and Sutherland, W.J., 2008, Predicting population responses to restoration of breeding habitat in Atlantic salmon: Journal of Applied Ecology, v. 45, no. 3, p. 930-938, [Also available at http://dx.doi.org/10.1111/j.1365-2664.2008.01464.x.]

Eloranta, A.P., Helland, I.P., Sandlund, O.T., Hesthagen, T., Ugedal, O., and Finstad, A.G., 2016, Community structure influences species' abundance along environmental gradients: Journal of Animal Ecology, v. 85, no. 1, p. 273-282, [Also available at http://dx.doi.org/10.1111/13652656.12461.]

Fischenich, J.C., Marmorek, D.R., Nelitz, M.A., Murray, C.L., Ma, B.O., Buenau, K.E., Long, G., Bonneau, J.L., Fleming, C.A., and Schwarz, C.J., In Review, Science and Adaptive Management Plan: Missouri River Recovery Program ERDC/EL TR-16-XX -Draft, 597 p.

Forero, M.G., Tella, J.L., Hobson, K.A., Bertellotti, M., and Blanco, G., 2002, Conspecific food competition explains variability in colony size: A test in magellanic penguins: Ecology, v. 83, no. 12, p. 34663475, [Also available at http://dx.doi.org/10.1890/0012-9658(2002)083[3466:CFCEVI]2.0.CO;2.]

French, W.E., Graeb, B.D.S., Bertrand, K.N., Chipps, S.R., and Klumb, R.A., 2013, Size-dependent trophic patterns of pallid sturgeon and shovelnose sturgeon in a large river system: Journal of Fish and Wildlife Management, v. 4, no. 1, p. 41-52, [Also available at http://dx.doi.org/10.3996/022012jfwm-013.]

Funk, J.L., and Robinson, J.W., 1974, Changes in the channel of the lower Missouri River and effects on fish and wildlife: Missouri Department of Conservation.

Galat, D.L., and Lipkin, R., 2000, Restoring ecological integrity of great rivers: Historical hydrographs aid in defining reference conditions for the Missouri River: Hydrobiologia, v. 422, p. 29-48, [Also available at http://dx.doi.org/10.1023/A:1017052319056.]

Gerrity, P.C., Guy, C.S., and Gardner, W.M., 2006, Juvenile pallid sturgeon are piscivorous: A call for conserving native cyprinids: Transactions of the American Fisheries Society, v. 135, no. 3, p. 604-609, [Also available at http://dx.doi.org/10.1577/t05-122.1.]

Graham, M., 1935, Modern theory of exploiting a fishery and applications to North Sea trawling.: J. Cons. Int. Exp. Mer, v. 10, p. 264-274, [Also available at http://dx.doi.org/10.1093/icesjms/10.3.264.]

Grohs, K.L., Klumb, R.A., Chipps, S.R., and Wanner, G.A., 2009, Ontogenetic patterns in prey use by pallid sturgeon in the Missouri River, South Dakota and Nebraska: Journal of Applied Ichthyology, v. 25, p. 48-53, [Also available at http://dx.doi.org/10.1111/j.1439-0426.2009.01279.x.]

Hadley, G.L., and Rotella, J.J., 2009, Upper basin pallid sturgeon survival estimation project final report, $35 \mathrm{p}$. 
Hallberg, G.R., Harbaugh, J.M., and Witinok, P.M., 1979, Changes in the channel area of the Missouri River in lowa, 1879-1976: lowa Geological Survey, 32 p.

Hartman, K.J., Margraf, F.J., Hafs, A.W., and Cox, M.K., 2015, Bioelectrical impedance analysis: A new tool for assessing fish condition: Fisheries, v. 40, no. 12, p. 590-600, [Also available at http://dx.doi.org/10.1080/03632415.2015.1106943.]

Heim, K.C., Wipfli, M.S., Whitman, M.S., and Seitz, A.C., 2016, Body size and condition influence migration timing of juvenile Arctic grayling: Ecology of freshwater fish, no. 1, [Also available at http://dx.doi.org/10.1111/eff.12199.]

Heironimus, L.B., 2014, The development and application of a larval pallid sturgeon (Scaphirhynchus albus) bioenergetics model: South Dakota State University, M.S. Thesis, 84 p., [Also available at https://www.researchgate.net/publication/267898769_Development_and_Application_of_a_La rval_Pallid_Sturgeon_Bioenergetics_Model.]

Hesse, L.W., and Sheets, W., 1993, The Missouri River hydrosystem: Fisheries, v. 18, no. 5, p. 5-14, [Also available at http://dx.doi.org/10.1577/1548-8446(1993)018<0005:tmrh>2.0.co;2.]

Hossain, M.Y., Rahman, M.M., and Abdallah, E.M., 2012, Relationships between body size, weight, condition and fecundity of the threatened fish Puntius ticto (Hamilton, 1822) in the Ganges River, Northwestern Bangladesh: SAINS MALAYSIANA, v. 41, no. 7, p. 803-814, [Also available at https://login.proxy.library.msstate.edu/login?url=http://search.ebscohost.com/login.aspx?direc $\mathrm{t}=$ true \&db=edswsc\&AN=000306770500002\&site=eds-live.]

Howell, P.J., Colvin, M.E., Sankovich, P.M., Buchanan, D.V., and Hemmingsen, A.R., 2016, Life histories, demography, and distribution of a fluvial bull trout population: Transactions of the American Fisheries Society, v. 145, no. 1, p. 173-194, [Also available at http://dx.doi.org/10.1080/00028487.2015.1105870.]

Huenemann, T., 2016, Central Lowlands and Interior Highlands pallid sturgeon spawning and stocking summary 1992 - 2015: Nebraska Game and Parks Commission, 128 p.

Huenemann, T.W., Steffensen, K.D., Mestl, G.E., Shuman, D.A., and Stukel, S., 2015, The Status of Fishes in the Missouri River, Nebraska: Emerald Shiner (Notropis atherinoides), Red Shiner (Cyprinella lutrensis), River Shiner (N. blennius), Sand Shiner (N. stramineus), Spotfin Shiner (C. spiloptera): Transactions of the Nebraska Academy of Science, v. 35, p. 15-33.

Jacobson, R.B., Annis, M.L., Colvin, M.E., James, D.A., Welker, T.L., and Parsley, M.J., 2016, Missouri River Scaphirhynchus albus (Pallid Sturgeon) Effects Analysis-Integrative Report 2016: U.S. Geological Survey Scientific Investigations Report 2016-5064, 154 p., [Also available at http://dx.doi.org/10.3133/sir20165064.]

Jacobson, R.B., Annis, M.L., Parsley, M.J., James, D.A., Colvin, M.E., and Welker, T.L., 2015, Science information to support Missouri River Scaphirhynchus albus (pallid sturgeon) effects analysis: U.S. Geological Survey Open-file Report 2015-1226, 78 p., [Also available at https://pubs.er.usgs.gov/publication/ofr20151226.]

Jacobson, R.B., Blevins, D.W., and Bitner, C.J., 2009, Sediment regime constraints on river restoration: An example from the Lower Missouri River: The Geological Society of American -Special Paper, v. 451, [Also available at http://specialpapers.gsapubs.org/content/451/1.short.]

Jacobson, R.B., Elliott, C.M., and Huhmann, B.L., 2010, Development of a channel classification to evaluate potential for cottonwood restoration, lower segments of the Middle Missouri River, South Dakota and Nebraska: U.S. Geological Survey Scientific Investigations Report 2010-5208, 38 p., [Also available at http://pubs.usgs.gov/sir/2010/5208.]

Jacobson, R.B., and Galat, D.L., 2006, Flow and form in rehabilitation of large-river ecosystems: An example from the Lower Missouri River: Geomorphology, v. 77, no. 3-4, p. 249-269, [Also available at http://dx.doi.org/10.1016/j.geomorph.2006.01.014.] 
Jacobson, R.B., Parsley, M.J., Annis, M.L., Colvin, M.E., Welker, T.L., and James, D.A., 2015, Development of conceptual ecological models linking management of the Missouri River to pallid sturgeon population dynamics: U.S. Geological Survey Open-File Report 2015-1038, 47 p., [Also available at http://dx.doi.org/10.3133/ofr20151038.]

Jacobson, R.B., Parsley, M.J., Annis, M.L., Colvin, M.E., Welker, T.L., and James, D.A., 2016, Development of working hypotheses linking management of the Missouri River to population dynamics of Scaphirhynchus albus (pallid sturgeon): U.S. Geological Survey Open-file Report 2015-1236, 33 p., [Also available at http://dx.doi.org/10.3133/ofr20151236.]

Jager, H.I., Bevelhimer, M.S., Lepla, K.B., Chandler, J.A., and Van Winkle, W., 2007, Evaluation of reconnection options for white sturgeon in the Snake River using a population viability model: American Fisheries Society Symposium, v. CONF 56, p. 319-338, [Also available at https://login.proxy.library.msstate.edu/login?url=http://search.ebscohost.com/login.aspx?direc

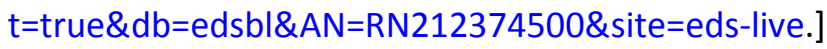

Jo, H., Ventura, M., Vidal, N., Gim, J.-S., Buchaca, T., Barmuta, L.A., Jeppesen, E., and Joo, G.-J., 2016, Discovering hidden biodiversity: the use of complementary monitoring of fish diet based on DNA barcoding in freshwater ecosystems: Ecology and Evolution, v. 6, no. 1, p. 219-232, [Also available at http://dx.doi.org/10.1002/ece3.1825.]

Kaspersson, R., Sundstrom, F., Bohlin, T., and Johnsson, J.I., 2013, Modes of competition: adding and removing brown trout in the wild to understand the mechanisms of density-dependence: PLoS One, v. 8, no. 5, p. 1-9, [Also available at http://dx.doi.org/10.1371/journal.pone.0062517.]

Keeley, E.R., 2001, Demographic responses to food and space competition by juvenile steelhead trout: Ecology, v. 82, no. 5, p. 1247-1259, [Also available at http://dx.doi.org/10.1890/00129658(2001)082[1247:DRTFAS]2.0.CO;2.]

Kent, M.L., Benda, S., St-Hilaire, S., and Schreck, C.B., 2013, Sensitivity and specificity of histology for diagnoses of four common pathogens and detection of non-target pathogens in adult Chinook salmon in freshwater: Journal of Veterinary Diagnostic Investigation, v. 25, p. 341-351, [Also available at http://dx.doi.org/10.1177/1040638713482124.]

Kitchell, J.F., Koonce, J.F., Oneill, R.V., Shugart, H.H., Magnuson, J.J., and Booth, R.S., 1974, Model of fish biomass dynamics: Transactions of the American Fisheries Society, v. 103, no. 4, p. 786-798, [Also available at http://dx.doi.org/10.1577/1548-8659(1974)103<786:MOFBD>2.0.CO;2.]

Kitchell, J.F., Stewart, D.J., and Weininger, D., 1977, Applications of a bioenergetics model to yellow perch (Perca-Flavescens) and walleye (Stizostedion-Vitreum-Vitreum): Journal of the Fisheries Research Board of Canada, v. 34, p. 1922-1935, [Also available at http://dx.doi.org/10.1139/f77258.]

Koops, M.A., Hutchings, J.A., and Mclntyre, T.M., 2013, Testing hypotheses about fecundity, body size and maternal condition in fishes: Fish and Fisheries, v. 5, no. 2, p. 120-130, [Also available at http://dx.doi.org/10.1111/j.1467-2979.2004.00149.x.]

Liao, H., Pierce, C.L., and Larscheid, J.G., 2005, An empirical model for estimating annual consumption by freshwater fish populations: North American Journal of Fisheries Management, v. 25, p. 525535, [Also available at http://dx.doi.org/10.1577/M03-213.1.]

McElroy, B., DeLonay, A., and Jacobson, R., 2012, Optimum swimming pathways of fish spawning migration in rivers: Ecology, v. 93, no. 1, p. 29-34, [Also available at http://dx.doi.org/10.1890/11-1082.1.]

Mill, A.C., Pinnegar, J.K., and Polunin, N.V.C., 2007, Explaining isotope trophic-step fractionation: Why herbivorous fish are different: Functional Ecology, v. 21, no. 6, p. 1137-1145, [Also available at http://www.jstor.org/stable/20142756.] 
Mittelbach, G.G., 1988, Competition among refuging sunfishes and effects of fish density on littoral zone invertebrates: Ecology, v. 69, no. 3, p. 614-623, [Also available at http://dx.doi.org/10.2307/1941010.]

Modde, T., and Schmulbach, J.C., 1977, Food and feeding behavior of the shovelnose sturgeon, Scaphirhynchus platorynchus, in the unchannelized Missouri River: Transactions of the American Fisheries Society, v. 106, no. 6, p. 602-608.

Mommsen, T.P., Vijayan, M.M., and Moon, T.W., 1999, Cortisol in teleosts: Dynamics, mechanisms of action, and metabolic regulation: Reviews in Fish Biology and Fisheries, v. 9, no. 3, p. 211-268, [Also available at http://dx.doi.org/10.1023/A:1008924418720.]

Murphy, D.D., and Weiland, P.S., 2011, The route to best science in implementation of the Endangered Species Act's consultation mandate: The benefits of structured effects analysis: Environmental Management, v. 47, no. 2, p. 161-172, [Also available at http://www.ncbi.nlm.nih.gov/pubmed/21161526.]

National Research Council, 2011, Missouri River planning: Recognizing and incorporating sediment management: Washington, D.C., The National Academies Press, 165 p.

Nitschke, P., Mather, M., and Juanes, F., 2001, A Comparison of Length-, Weight-, and Age-Specific Fecundity Relationships for Cunner in Cape Cod Bay: North American Journal of Fisheries Management, v. 21, no. 1, p. 86-95, [Also available at http://dx.doi.org/10.1577/15488675(2001)021<0086:ACOLWA>2.0.CO;2.]

Osenberg, C.W., Olson, M.H., and Mittelbach, G.G., 1994, Stage structure in fishes: resource productivity and competition gradients., chap. of Strouder, D.J., Fresh, K.L., and Feller, R.J. eds., Theory and application in fish feeding ecology, Vol. 18: Columbia, SC, Belle W. Baruch Library in Marine Sciences.

Palomares, M.L.D., and Pauly, D., 1998, Predicting food consumption of fish populations as functions of mortality, food type, morphometrics, temperature and salinity: Marine and Freshwater Research, v. 49, no. 5, p. 447-453, [Also available at http://dx.doi.org/10.1071/MF98015.]

Papoulias, D.M., Tillitt, D.E., Annis, M.L., Nicks, D., and Schwarz, M.S., 2010, Laboratory evaluation of effects of early life-stage exposure to selenium on pallid and shovelnose sturgeon: in American Fisheries Society Larval Fish Conference, Pittsburg, 2010,p.

Pauly, D., Christensen, V., and Walters, C., 2000, Ecopath, Ecosim, and Ecospace as tools for evaluating ecosystem impact of fisheries: ICES Journal of Marine Science, v. 57, no. 3, p. 697-706, [Also available at http://dx.doi.org/10.1006/jmsc.2000.0726.]

Pegg, M.A., Pierce, C.L., and Roy, A., 2003, Hydrological alteration along the Missouri River basin: A time series approach: Aquatic Science, v. 65, no. 1, p. 63-72, [Also available at http://dx.doi.org/10.1007/s000270300005.]

Pendleton, R.M., Schwinghamer, C., Solomon, L.E., and Casper, A.F., 2017, Competition among river planktivores: are native planktivores still fewer and skinnier in response to the Silver Carp invasion?: Environmental Biology of Fishes, [Also available at https://doi.org/10.1007/s10641017-0637-7.]

Persson, L., 1997, Competition, predation and environmental factors as structuring forces in freshwater fish communities: Sumari (1971) revisited: Canadian Journal of Fisheries and Aquatic Sciences, v. 54, no. 1, p. 85-88, [Also available at http://dx.doi.org/10.1139/f96-250.]

Phillips, D.L., and Eldridge, P.M., 2006, Estimating the timing of diet shifts using stable isotopes: Oecologia, v. 147, no. 2, p. 195-203, [Also available at http://dx.doi.org/10.1007/s00442-0050292-0.]

Pickering, A.D., 1993, Growth and stress in fish production: Aquaculture, v. 111, no. 1, p. 51-63, [Also available at http://dx.doi.org/10.1016/0044-8486(93)90024-S.] 
Pinter, N., 2010, Historical discharge measurements on the Middle Mississippi River, U.S.A.: No basis for 'changing history': Hydrological Processes, v. 24, no. 8, p. 1088-1093, [Also available at http://dx.doi.org/10.1002/hyp.7653.]

Pinter, N., and Heine, R.A., 2005, Hydrodynamic and morphodynamic response to river engineering documented by fixed-discharge analysis, Lower Missouri River, U.S.A.: Journal of Hydrology, v. 302, no. 1-4, p. 70-91, [Also available at http://dx.doi.org/10.1016/j.jhydrol.2004.06.039.]

Polovina, J.J., 1984, Model of a coral reef ecosystem: Coral Reefs, v. 3, no. 1, p. 1-11, [Also available at http://dx.doi.org/10.1007/BF00306135.]

Radtke, R.L., Lenz, P., Showers, W., and Moksness, E., 1996, Environmental information stored in otoliths: Insights from stable isotopes: Marine Biology, v. 127, no. 1, p. 161-170, [Also available at http://dx.doi.org/10.1007/BF00993656.]

Randall, R.G., and Minns, C.K., 2000, Use of fish production per unit biomass ratios for measuring the productive capacity of fish habitats: Canadian Journal of Fisheries and Aquatic Sciences, v. 57, no. 8, p. 1657-1667, [Also available at http://dx.doi.org/10.1139/f00-103.]

Rapp, T., Shuman, D.A., Graeb, B.D.S., Chipps, S.R., and Peters, E.J., 2011, Diet composition and feeding patterns of adult shovelnose sturgeon (Scaphirhynchus platorynchus) in the lower Platte River, Nebraska, USA: Journal of Applied Ichthyology, v. 27, no. 2, p. 351-355, [Also available at http://dx.doi.org/10.1111/j.1439-0426.2011.01743.x.]

Rätz, H.-J., and Lloret, J., 2003, Variation in fish condition between Atlantic cod (Gadus morhua) stocks, the effect on their productivity and management implications: Fisheries Research, v. 60, no. 2-3, p. 369-380, [Also available at http://dx.doi.org/10.1016/S0165-7836(02)00132-7.]

Reuter, J.M., Jacobson, R.B., Elliott, C.M., and DeLonay, A.J., 2009, Assessment of Lower Missouri River Physical Aquatic Habitat and Its Use by Adult Sturgeon (Genus Scaphirhynchus), 2005-07: 20095121, [Also available at http://pubs.usgs.gov/sir/2009/5121/.]

Ricker, W.E., 1975, Computation and interpretation of biological statistics of fish populations. Bulletin of the Fisheries Research Board of Canada: Bulletin 191: Ottawa, Canada, Department of the Environment Fisheries and Marine Service.

Rideout, R.M., and Morgan, M.J., 2010, Relationships between maternal body size, condition and potential fecundity of four north-west Atlantic demersal fishes: Journal of Fish Biology, v. 76, no. 6, p. 1379-1395, [Also available at http://dx.doi.org/10.1111/j.1095-8649.2010.02570.x.]

Rotella, J.J., and Hadley, G.L., 2010, Upper Basin Pallid Sturgeon Survival Estimation Project 2010 Update, $64 \mathrm{p}$.

Roy, N.K., Walker, N., Chambers, R.C., and Wirgin, I., 2011, Characterization and expression of cytochrome P4501A in Atlantic sturgeon and shortnose sturgeon experimentally exposed to coplanar PCB 126 and TCDD: Aquatic Toxicology, v. 104, no. 1-2, p. 23-31, [Also available at http://dx.doi.org/10.1016/j.aquatox.2011.03.009.]

Rutherford, E.S., Rose, K.A., Mills, E.L., Forney, J.L., Mayer, C.M., and Rudstam, L.G., 1999, Individualbased model simulations of a zebra mussel (Dreissena polymorpha) induced energy shunt on walleye (Stizostedion vitreum) and yellow perch (Perca flavescens) populations in Oneida Lake, New York: Canadian Journal of Fisheries and Aquatic Sciences, v. 56, no. 11, p. 2148-2160, [Also available at http://dx.doi.org/10.1139/cjfas-56-11-2148.]

Schrey, A.W., and Heist, E.J., 2007, Stock structure of pallid sturgeon analyzed with microsatellite loci: Journal of Applied Ichthyology, v. 23, no. 4, p. 297-303, [Also available at http://dx.doi.org/10.1111/j.1439-0426.2007.00881.x.]

Shuman, D.A., Klumb, R.A., Wilson, R.H., Jaeger, M.E., Haddix, T., Gardner, W.M., Doyle, W.J., Horner, P.T., Ruggles, M., Steffensen, K.D., Stukel, S., and Wanner, G.A., 2011, Pallid sturgeon size structure, condition, and growth in the Missouri River Basin: Journal of Applied Ichthyology, v. 27, no. 2, p. 269-281, [Also available at http://dx.doi.org/10.1111/j.1439-0426.2010.01645.x.] 
Shuman, D.A., Willis, D.W., and Krentz, S.C., 2006, Application of a length-categorization system for pallid sturgeon (Scaphirhynchus albus): Journal of Freshwater Ecology, v. 21, no. 1, p. 71-76, [Also available at http://dx.doi.org/10.1080/02705060.2006.9664098.]

Simon, K.S., and Townsend, C.R., 2003, Impacts of freshwater invaders at different levels of ecological organisation, with emphasis on salmonids and ecosystem consequences: Freshwater Biology, v. 48, no. 6, p. 982-994, [Also available at http://dx.doi.org/10.1046/j.1365-2427.2003.01069.x.]

Slotte, A., 1999, Effects of fish length and condition on spawning migration in Norwegian spring spawning herring (Clupea harengus L.): Sarsia, v. 84, no. 2, p. 111-127, [Also available at http://dx.doi.org/10.1080/00364827.1999.10420439.]

Steffensen, K.D., and Mestl, G.E., 2016, Assessment of pallid sturgeon relative condition in the upper channelized Missouri River: Journal of Freshwater Ecology, p. 1-13, [Also available at http://dx.doi.org/10.1080/02705060.2016.1196465.]

Steffensen, K.D., Mestl, G.E., and Phelps, Q.E., 2016, Range-wide assessment of pallid sturgeon Scaphirhynchus albus (Forbes \& Richardson, 1905) relative condition: Journal of Applied Ichthyology, p. n/a-n/a, [Also available at http://dx.doi.org/10.1111/jai.13206.]

Steffensen, K.D., Pegg, M.A., and Mestl, G., 2013a, Population prediction and viability model for pallid sturgeon (Scaphirhynchus albus, Forbes and Richardson, 1905) in the lower Missouri River: Journal of Applied Ichthyology, v. 29, no. 5, p. 984-989, [Also available at http://dx.doi.org/10.1111/Jai.12277.]

Steffensen, K.D., Pegg, M.A., and Mestl, G.E., 2013b, Population characteristics of pallid sturgeon (Scaphirhynchus albus (Forbes \& Richardson)) in the Lower Missouri River: Journal of Applied Ichthyology, v. 29, no. 4, p. 687-695, [Also available at http://dx.doi.org/10.1111/jai.12196.]

Steffensen, K.D., Powell, L.A., and Koch, J.D., 2010, Assessment of hatchery-reared pallid sturgeon survival in the Lower Missouri River: North American Journal of Fisheries Management, v. 30, no. 3, p. 671-678, [Also available at http://dx.doi.org/10.1577/m09-151.1.]

Steffensen, K.D., Shuman, D.A., and Stukel, S., 2014, The status of fishes in the Missouri River, Nebraska: shoal chub, sturgeon chub, sicklefin chub, silver chub, flathead chub, plains minnow, western silvery minnow, and brassy minnow: Transactions of the Nebraska Academy of Sciences and Affiliated Societies Paper 465, 49-67 p., [Also available at http://digitalcommons.unl.edu/cgi/viewcontent.cgi?article=1467\&context=tnas.]

Steffensen, K.D., Stukel, S., and Shuman, D.A., 2014, The status of fishes in the Missouri River, Nebraska: shovelnose sturgeon: Transactions of the Nebraska Academy of Sciences and Affiliated Societies Paper 465, 16-26 p., [Also available at http://digitalcommons.unl.edu/cgi/viewcontent.cgi?article=1467\&context=tnas.]

Sun, J., Robinson, A., and Davis, J.A., 2016, Selenium in sturgeon muscle plugs: 2014: San Francisco Estuary Institute - Aquatic Science Center Contribution \# 774, 15 p.

Svanbäck, R., and Bolnick, D.I., 2007, Intraspecific competition drives increased resource use diversity within a natural population: Proceedings of the Royal Society B: Biological Sciences, v. 274, no. 1611, p. 839-844, [Also available at http://dx.doi.org/10.1098/rspb.2006.0198.]

Svanbäck, R., Eklöv, P., Fransson, R., and Holmgren, K., 2008, Intraspecific competition drives multiple species resource polymorphism in fish communities: Oikos, v. 117, no. 1, p. 114-124, [Also available at http://dx.doi.org/10.1111/j.2007.0030-1299.16267.x.]

Tillitt, D.E., Nicks, D.K., Candrl, J.S., Annis M.L., and Papoulias, D.M., 2004, Determination of the relationship between concentrations of TCDD or chlordane in sturgeon eggs and early life stage development and survival: U.S. Geological Survey FY 2004-30-07, 47 p.

U.S. Army Corps of Engineers, 2003, Final supplemental environmental impact statement (FSEIS) for the modified Missouri River Fish and Wildlife Mitigation Project: U.S. Army Corps of Engineers. 
U.S. Army Corps of Engineers, 2012, Missouri River Stage Trends: U.S. Army Corps of Engineers, Northwestern Division, Reservoir Control Center Technical Report, 46 p.

U.S. Fish and Wildlife Service, 2000, Biological opinion on the operation of the Missouri River main stem reservoir system, operation and maintenance of the Missouri River bank stabilization and navigation project, and operation of the Kansas River reservoir system: U.S. Fish and Wildlife Service, $296 \mathrm{p}$.

U.S. Fish and Wildlife Service, 2003, Amendment to the 2000 biological opinion on the operation of the Missouri River main stem reservoir system, operation and maintenance of the Missouri River bank stabilization and navigation project, and operation of the Kansas River reservoir system: U.S. Army Corps of Engineers, 12 p.

U.S. Fish and Wildlife Service, 2006, National pallid sturgeon database: Bismarck, North Dakota.

U.S. Fish and Wildlife Service, 2014, Revised recovery plan for the pallid sturgeon (Scaphirhynchus albus): U.S. Fish and Wildlife Service, 115 p.

U.S. Geological Survey, 2016, National Water Information System data available on the World Wide Web (USGS Water Data for the Nation), accessed January 3, 2017, at http://waterdata.usgs.gov/nwis/.

van Oevelen, D., Van den Meersche, K., Meysman, F., Soetaert, K., Middelburg, J., and Vézina, A., 2010, Quantifying food web flows using linear inverse models: Ecosystems, v. 13, no. 1, p. 32-45, [Also available at http://dx.doi.org/10.1007/s10021-009-9297-6.]

VanDeValk, A.J., Forney, J.L., and Jackson, J.R., 2008, Relationships between relative weight, prey availability, and growth of walleyes in Oneida Lake, New York: North American Journal of Fisheries Management, v. 28, no. 6, p. 1868-1875, [Also available at http://dx.doi.org/10.1577/M08-064.1.]

Walters, C., Christensen, V., and Pauly, D., 1997, Structuring dynamic models of exploited ecosystems from trophic mass-balance assessments: Reviews in Fish Biology and Fisheries, v. 7, no. 2, p. 139-172, [Also available at http://dx.doi.org/10.1023/A:1018479526149.]

Walters, C., Pauly, D., and Christensen, V., 1999, Ecospace: Prediction of mesoscale spatial patterns in trophic relationships of exploited ecosystems, with emphasis on the impacts of marine protected areas: Ecosystems, v. 2, no. 6, p. 539-554, [Also available at http://dx.doi.org/10.1007/s100219900101.]

Walters, C.J., and Essington, T.E., 2010, Recovery of bioenergetics parameters from information on growth: Overview of an approach based on statistical analysis of tagging and size-at- age data: The Open Fish Science Journal, p. 52-68, [Also available at http://dx.doi.org/10.2174/1874401X01003010052.]

Wanner, G.A., Shuman, D.A., and Willis, D.W., 2007, Food habits of juvenile pallid sturgeon and adult shovelnose sturgeon in the Missouri River downstream of Fort Randall Dam, South Dakota: Journal of Freshwater Ecology, v. 22, no. 1, p. 81-92, [Also available at http://dx.doi.org/10.1080/02705060.2007.9664148.]

Webster, M.S., and Hixon, M.A., 2000, Mechanisms and individual consequences of intraspecific competition in a coral-reef fish: Marine Ecology Progress Series, v. 196, p. 187-194, [Also available at http://dx.doi.org/10.3354/meps196187.]

Welker, T.L., and Drobish, M.R., 2016, Missouri River standard operating procedures for fish sampling and data collection, v. 1.8: U.S. Army Corps of Engineers, 193 p.

White, G.C., and Burnham, K.P., 1999, Program MARK: Survival estimation from populations of marked animals: Bird Study 46 Supplement, p. 120-138, [Also available at http://dx.doi.org/10.1080/00063659909477239.]

Wildhaber, M.L., Albers, J.L., Green, N.S., and Moran, E.H., 2015, A fully-stochasticized, age-structured population model for population viability analysis of fish: Lower Missouri River endangered 
pallid sturgeon example: Ecological Modelling, [Also available at http://dx.doi.org/10.1016/j.ecolmodel.2015.07.019.]

Wildhaber, M.L., Dey, R., Wikle, C.K., Moran, E.H., Anderson, C.J., and Franz, K.J., 2015, A stochastic bioenergetics model-based approach to translating large river flow and temperature into fish population responses: the pallid sturgeon example: Geological Society, London, Special Publications, v. 408, [Also available at http://dx.doi.org/10.1144/SP408.10.]

Wildhaber, M.L., Wikle, C.K., Moran, E.H., Anderson, C.J., Franz, K.J., and Dey, R., 2015, Hierarchical stochastic modelling of large river ecosystems and fish growth across spatio-temporal scales and climate models: the Missouri River endangered pallid sturgeon example: Geological Society, London, Special Publications, v. 408, [Also available at http://dx.doi.org/10.1144/sp408.11.]

Winders, K.R., and Steffensen, K.D., 2014, Population size of pallid sturgeon, Scaphirhynchus albus (Forbes \& Richardson, 1905), in the Lower Missouri River near Kansas City, Missouri, U.S.A.: Journal of Applied Ichthyology, v. 30, no. 6, p. 1356-1361, [Also available at http://dx.doi.org/10.1111/jai.12558.]

Zee, J., Patterson, S., Gagnon, D., and Hecker, M., 2016, Adverse health effects and histological changes in white sturgeon (Acipenser transmontanus) exposed to dietary selenomethionine: Environmental Toxicology and Chemistry, v. 35, no. 7, p. 1741-1750, [Also available at http://dx.doi.org/10.1002/etc.3320.] 